\title{
ESTUDO GENÉTICO-EVOLUTIVO DE AMOSTRAS MODERNAS E ARQUEOLÓGICAS DE MILHO (Zea mays mays, L.) E FEIJÃO (Phaseolus vulgaris, L.)
}

\section{FÁBIO DE OLIVEIRA FREITAS}

Tese apresentada à Escola Superior de Agricultura "Luiz de Queiroz", Universidade de São Paulo, para obtenção do título de Doutor em Agronomia, Área de Concentração: Genética e Melhoramento de Plantas.

PIRACICABA

Estado de São Paulo - Brasil

Janeiro de 2001 


\title{
ESTUDO GENÉTICO-EVOLUTIVO DE AMOSTRAS MODERNAS E ARQUEOLÓGICAS DE MILHO (Zea mays mays, L.) E FEIJÃO (Phaseolus vulgaris, L.)
}

\author{
FÁBIO DE OLIVEIRA FREITAS \\ Engenheiro Agrônomo
}

Orientador: Prof. Dr. GERHARD BANDEL

\begin{abstract}
Tese apresentada à Escola Superior de Agricultura "Luiz de Queiroz", Universidade de São Paulo, para obtenção do título de Doutor em Agronomia, Área de Concentração: Genética e Melhoramento de Plantas.
\end{abstract}

PIRACICABA

Estado de São Paulo - Brasil

Janeiro de 2001 
Dados Internacionais de Catalogação na Publicação (CIP)

DIVISÃO DE BIBLIOTECA E DOCUMENTAÇÃOO - Campus “Luiz de Queiroz"/USP

Freitas, Fábio de Oliveira

Estudo genético-evolutivo de amostras modernas e arqueológicas de milho (Zea mays mays. L.) e feijão ( Phaseolus vulgaris, L.) / Fábio de Oliveira Freitas. - - Piracicaba, 2001.

125 p. : il.

Tese (doutorado) - Escola Superior de Agricultura Luiz de Queiroz, 2001.

Bibliografia.

1. Agricultura pré-história 2. Evolução vegetal 3. Feijão fóssil 4. Genética vegetal 5. Milho fóssil I. Título

CDD 561.49

"Permitida a cópia total ou parcial deste documento, desde que citada a fonte - $\mathrm{O}$ autor" 


\section{DEDICO,}

Dedico esta tese à todas as populações indígenas do passado, que plantaram, selecionaram e guardaram todo este material vegetal, que, muito tempo depois, tive a felicidade de poder observá-lo e estudá-lo. Também às do presente, pois foi em uma visita a uma delas que pude vir a conhecer a minha encantadora esposa.

\section{OFEREÇO}

Ofereço esta tese à minha família, esposa e a minha sobrinha, a qual transporta para o futuro algo dos meus genes. 


\section{AGRADECIMENTOS}

Quando me sento neste momento e começo a comparar os quatro anos de tese com os trinta e dois anos de vida, vejo mais do que uma simples relação de números múltiplos, vejo múltiplas bifurcações que surgiram ao longo da caminhada e que me levariam a outras vivências, mas somente esta que vivemos no presente é a que vingou, seja devido as escolhas, erros ou acertos que já fizemos. Do mesmo modo, as bifurcações que aparecerem no futuro são consequiências do caminho trilhado no momento.

O início da tese são como os primeiros passos de uma criança que começa a explorar e expandir o mundo que conhece, buscando aprender a ir e concretizar o que ainda é só desejo.

E este desejo nasceu na verdade há oito, nove anos atrás, através do amparo e dedicação de um orientador, o qual não apenas me ensinou saberes ao longo deste tempo, mas principalmente me ensinou como organizar e utilizar este saber. $\mathrm{E}$ ao atender ao chamado do Criador, $\mathrm{O}$ qual pôde assim desfrutar de uma mente brilhante em uma alma singela, humilde, nos deixou naquele momento atordoados.

Entretanto, hoje vejo que quando a lição é ensinada de forma correta, a sua força e mensagem perduram, mesmo após o livro ou a voz de ensinamento não existirem mais. Vira e mexe nos pegamos revolvendo o nosso celebro à procura daquele ensinamento construído, que se encaixe em determinada situação que vivenciamos e ficamos a pensar e dialogar mentalmente com nosso orientador, para continuarmos a construção, a qual possui a base sólida, exatamente porque ela foi construída sob a supervisão daquele.

E hoje, mesmo sentindo a falta de uma presença física mais próxima, para poder tirar as dúvidas mais facilmente ou ver o sorriso ao compartilhar a conquista do trabalho realizado, sinto que trago em minha alma a sua herança, o que me enche de orgulho, mas principalmente responsabilidade, pois sei o quanto devo fazer para poder retribuir todo o esforço e amparo a que ele se dedicou a mim. 
Deste modo, gostaria de agradecer e dedicar este trabalho ao meu eterno orientador, professor Paulo Sodero Martins, sem o qual seria um pesquisador com bom potencial, mas sem uma base sólida para tal.

Do outro lado da ciência, vem a parte humana de nossa formação, a qual este orientador também me ajudou muito, mas ao entrarmos em contato eu já estava lambuzado de amor, carinho e dedicação oferecido pelos meus pais, literalmente desde que eu me conheço por gente.

E a eles vai um carinho e agradecimento muito especial, os quais foram e continuam sendo meus grandes guias, que me deram tanto e são capazes de ficarem contentes com nossas próprias conquistas.

Carinho este que só cresceu com a presença extraordinária de minha esposa Joana, a qual está compartilhando comigo um lado magnífico e ao mesmo tempo difícil, da ciência da vida, integrando duas vidas em uma gostosa harmonia.

Ofereço um agradecimento especial ao Dr. Bandel, o qual aceitou ser meu orientador naquele momento de perda e desorientação e me permitiu, assim, continuar trilhando a linha mestra da pesquisa que já vinha desenvolvendo, na qual resulta esta tese, muito obrigado.

Assim como perdas ocorrem ao longo do caminho, ganhos inesperados também surgem e, deste modo tenho que agradecer muito ao apoio e dedicação que os meus dois orientadores estrangeiros, Dr. Terrence Brown e, principalmente, ao Dr. Robin Allabi, depositaram em mim. Eles receberam um pesquisador então com pouca experiência em genética molecular e muitas dúvidas e me deram a oportunidade de trabalhar e aprender muito e, o mais importante em termos científicos, permitiram que respostas para as perguntas desta tese pudessem ser respondidas.

Ainda podemos repassar na mente muitas pessoas que foram importantes na concretização desta tese. Pessoas de apoio, como a prof. Dra. Elizabeth Veassey, a quem muito me ajudou, membros do departamento de genética, como secretárias, como a Léia, bibliotecárias, faxineiras, técnicos de laboratórios, entre tantos outros.

Um agradecimento em especial vai ao Departamento de Genética da ESALQ e a esta própria Escola, que me acolheu desde meus passeios de bicicleta, antes da 
graduação, até os dias de hoje, me acolhendo pela beleza, harmonia e atmosfera cultural e científica que esta emana. Agradeço ainda ao CNPq e a CAPES, que me deram o apoio financeiro para concretizar meus estudos e pesquisas.

Agradeço ainda ao Dr. Kitagima, pela ajuda na revisão gramatical do meu ainda doloroso inglês.

Deste modo, agradeço a todos, citados ou apenas pensados, que me ajudaram a completar uma etapa importante de minha vida. 


\section{INDEX}

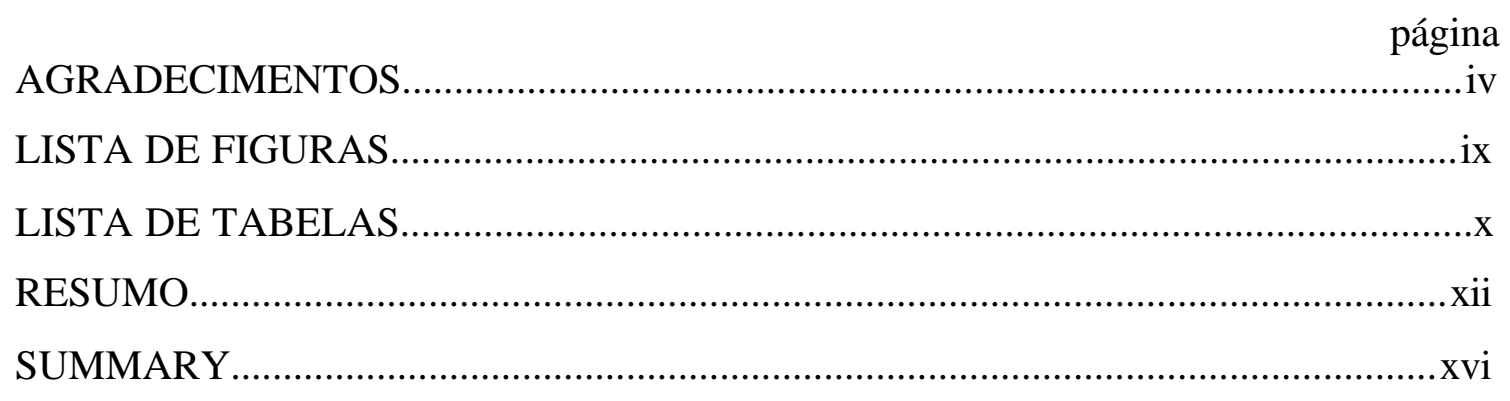

1. INTRODUÇÃ)

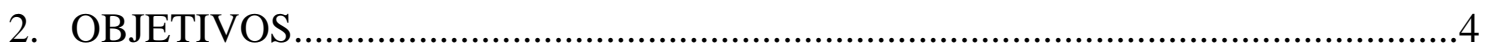

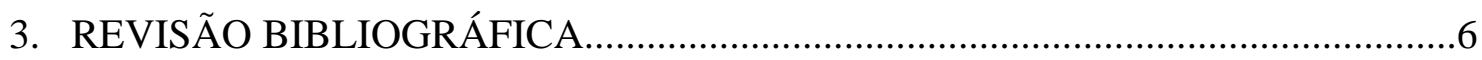

3.1 O gênero Zea - Lineu...................................................................................6

3.1.1 O ancestral do milho..................................................................................

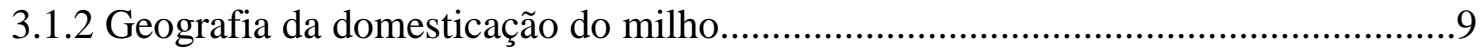

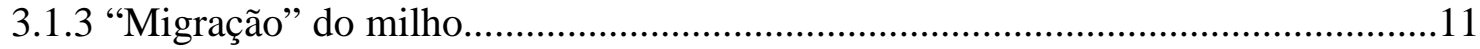

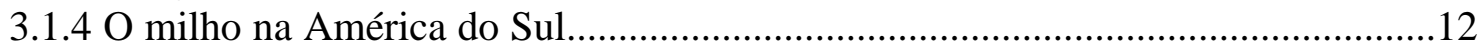

3.1.5 Milho em Sítios Arqueológicos do Brasil.........................................................16

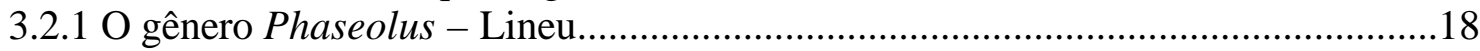

3.2.2 Local de origem do feijão.............................................................................19

3.2.3 Múltiplos centros de origem do feijão - Evidências............................................20

3.2.4 O período colonial brasileiro e o feijão...........................................................22

3.3 As bandeiras de entrada no sertão nordestino, o rio São Francisco e Januária.........22

3.4 Análise de Material Genético Extraído de Tecidos Arqueológicos..........................25

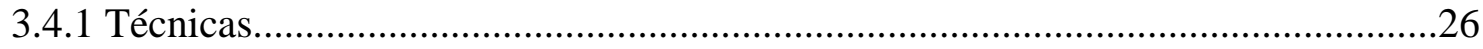

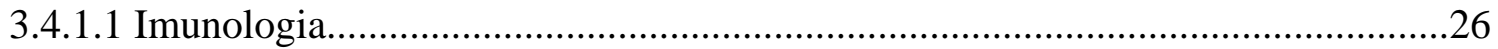

3.4.1.2 Extração de material genético de tecidos não vivos..........................................27

3.4.1.3 PCR - Reação em Cadeia da Polimerase............................................................27

3.4.2 Revisão de trabalhos com resgate e uso de material genético ancião......................29

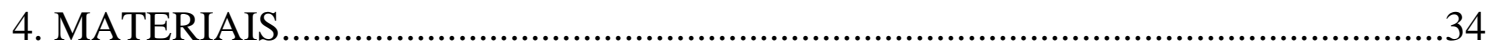

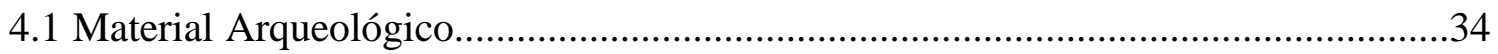

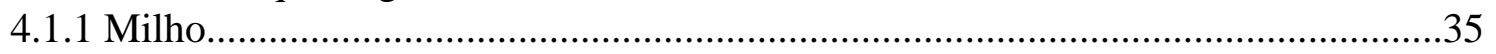

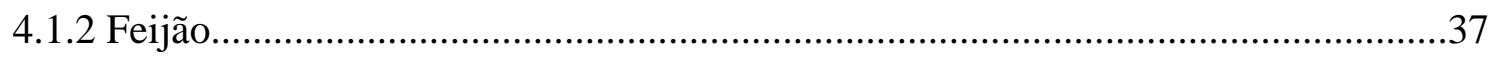

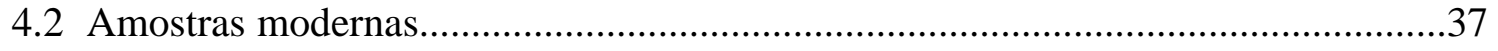

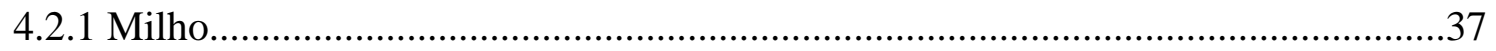

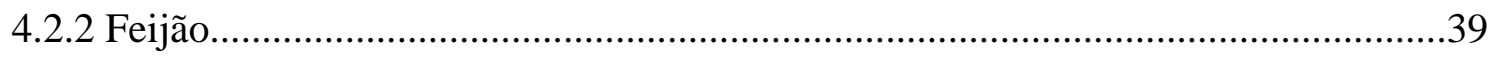

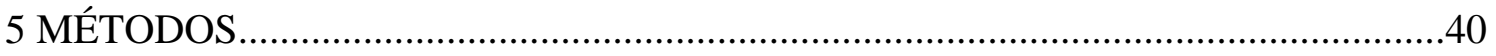

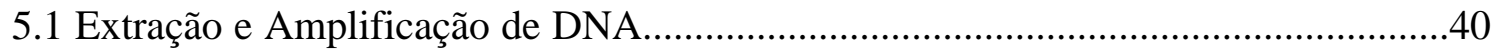

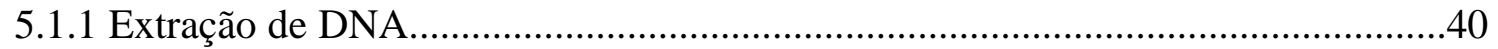

5.1.2 Purificação do material extraído......................................................................41 


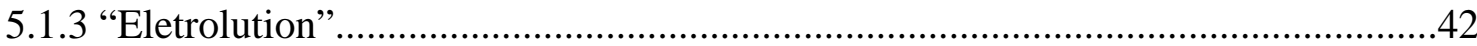

5.1.4 Amplificação do material - via PCR (reação de polimerização em cadeia)...........42

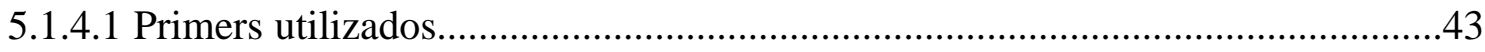

$5.2 \mathrm{Gel}$ de eletroforese..................................................................................44

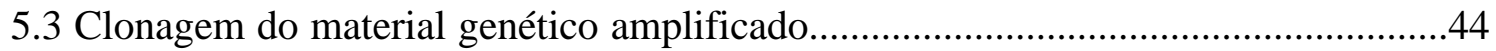

5.3.1. Digestão e junção da amostra de DNA com seu vetor.........................................44

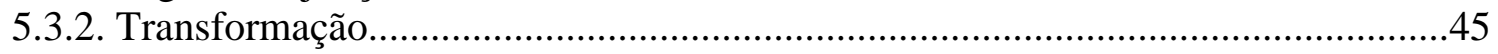

5.3.3 Identificação e utilização das bactérias transformadas.......................................46

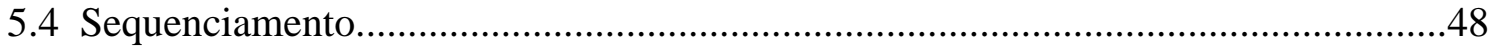

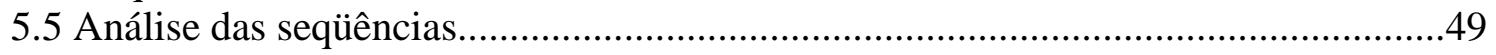

5.6 Procedimentos tomados para se evitar contaminação.........................................49

5.7 Datação das amostras arqueológicas.................................................................49

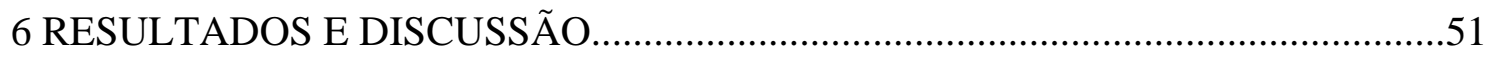

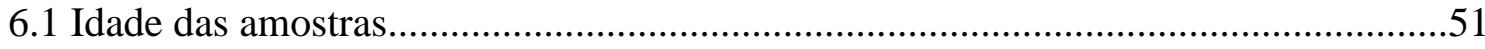

6.2 Amplificação, clonagem e seqüências obtidas..................................................52

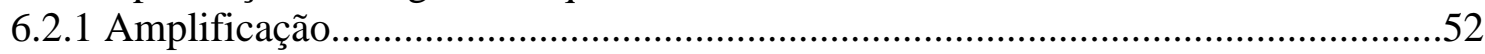

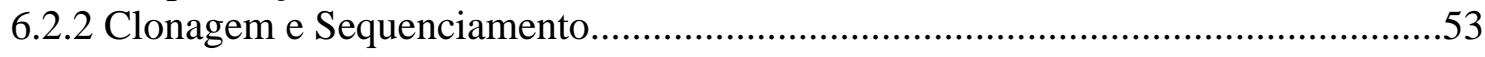

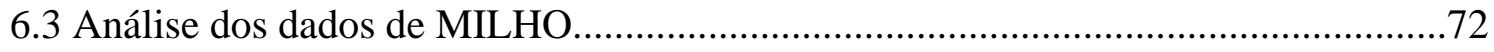

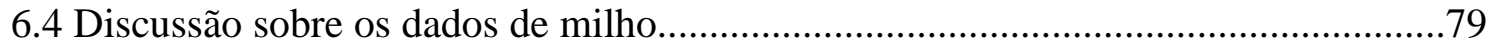

6.4.1 Expansão do milho para a América do Sul............................................................83

6.4.2 Considerações Finais para o Milho......................................................................92

6.5 Análise de Dados sobre as Amostras de Feijão.......................................................93

6.5.1 Análise dos dados da região PCR 1 ............................................................95

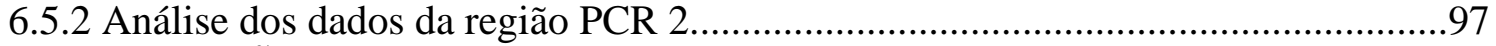

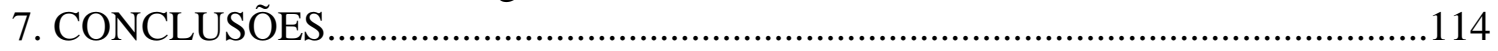

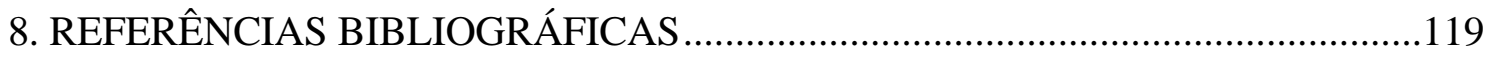




\section{LISTA DE FIGURAS}

Página

Figura 1. Mapa com a localização de Januária, de onde as amostras arqueológicas foram obtidas. .36

Figura 2. Vista geral da caverna "Lapa do Boquete", de onde parte das amostras arqueológicas vieram. 36

Figura 3. Duas espigas de milho arqeuológico, oriundas da "Lapa do Boquete", com idade de $1.010 \pm 60$ anos

Figura 4. Alinhamento das seqüências do fragmento do gene Adh2, em milho, com todas as amostras utilizadas e seus respectivos alelos. Note que todas as amostras iniciadas com a sigla "G" foram obtidas do trabalho de Goloumbinoff et al (1993) e a amostra "Dennis" foi obtida diretamente do banco mundial de sequiências genéticas

Figura 5. Alinhamento das seqüências do fragmento do gene Phaseolina - PCR 1 em feijão, com seus respectivos alelos. Note que as 9 (nove) últimas seqüências alinhadas foram obtidas diretamente do banco mundial de seqüências genéticas, sendo que destas, as duas últimas são da espécie $P$. lunatus, usadas neste trabalho como um "out group"....

Figura 6. Alinhamento das seqüências do fragmento do gene Phaseolina - PCR 2 em feijão, com seus respectivos alelos. Note que as 15 (quinze) últimas sequiências alinhadas foram obtidas diretamente do banco mundial de sequiências genéticas, sendo que destas, as duas últimas são da espécie $P$. lunatus, aqui usadas como um "out group"

Figura 7. Gráfico de network das amostras de milho utilizadas na análise. Os circulos escuros representam os parentes selvagens do Gênero Zea. As amostras com circulo duplo são prováveis híbridos e são detalhados no texto. .72

Figura 8. Mapa com os locais de origem de cada amostra de milho analisada e seus respectivos tipos de microsatélites presentes. .78

Figura 9. Mapa mostrando os principais tipos da proteína Phaseolina, a região onde ocorrem predominantemente e a cor que adotamos para representá-las. Note que a amostra arqueológica de Januária recebeu a sigla " $A$ ". . .98

Figura 10 . Diagrama de network para a região de PCR2, de feijão. Cada tipo de phaseolina esta representada por uma cor diferente e sua respectiva sigla utilizada na literatura. Note que a amostra arqueológica recebe a sigla "A". 


\section{LISTA DE TABELAS}

Página

Tabela 1. Distribuição e classificação das espécies e subespécies do Gênero Zea............7

Tabela 2. Tipo de phaseolina encontrada em populações de feijão selvagem e domesticado e sua origem geográfica (adaptado de Gepts \& Debouck, 1991)......21

Tabela 3. Amostras arqueológicas de milho utilizadas nas análises; sigla de referência de campo; local em que as amostras foram encontradas e a parte do material que foi utilizado nas análises. Note que as amostras que trabalhamos diretamente se encontram no quadro superior e as obtidas na literatura são apresentadas no inferior.

Tabela 4. Amostras arqueológicas de feijão utilizadas nas análises, sigla de referência de campo, local em que as amostras foram encontradas e a parte do material que foi utilizado nas análises.

Tabela 5. Amostras modernas de milho utilizadas nas análises; fonte destas amostras e sua identificação; raças a qual pertencem; local em que as amostras foram coletadas e a parte do material que foi utilizado nas análises. Novamente, as amostras que trabalhamos diretamente se encontram no quadro superior e as obtidas na literatura são apresentadas no inferior. .38

Tabela 6. Amostras modernas de feijão utilizadas nas análises, seu número de identificação no CIAT, local em que as amostras foram coletadas e a parte do material que foi utilizado nas análises 39

Tabela 7. Sigla, local e idade de cada amostra de milho arqueológico. Note que a amostra A34 ainda não possui idade determinada.

Tabela 8. Sigla, local e idade de cada amostra de milho arqueológico. Dados obtidos em Goloumbinoff et al (1993).

Tabela 9. Sigla, local e idade de cada amostra de feijão arqueológico .52

Tabela 10. Amostras de milho arqueológicas e modernas analisadas e seus respectivos números de clones obtidos e de alelos diferentes encontrados em cada amostra...54

Tabela 11. Amostras de feijão utilizadas, localização, tipo de Phaseolina de cada amostra, número de clones obtidos e respectivos números de alelos diferentes encontrados em cada amostra, para as duas regiões alvos do PCR 
Tabela 12. Resumo dos tipos de microsatélites encontrados nas amostras de milho, seu tamanho, sigla e nome da amostra, sua idade e número de clones obtidos de cada

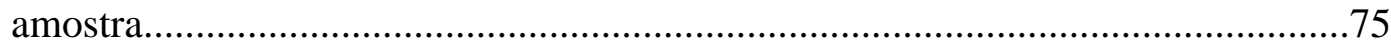

Tabela 13. Resumo dos tipos de microsatélites encontrados nas amostras.....................77 


\section{ESTUDO GENÉTICO-EVOLUTIVO DE AMOSTRAS MODERNAS E ARQUEOLÓGICAS DE MILHO (Zea mays mays, L.) E FEIJÃO (Phaseolus vulgaris, L.)}

Autor: Fábio de Oliveira Freitas

Orientador: Prof. Dr. Gerhard Bandel

RESUMO

Sete amostras arqueológicas de milho Zea mays mays, Lineu), com idades estimadas por $\mathrm{C}_{14}$ que variam entre $620 \pm 60$ anos e $990 \pm 60$ anos antes do presente e uma amostra arqueológica de feijão (Phaseolus vulgaris, Lineu) com idade de $301 \pm 39$ anos, oriundas de cavernas localizadas no Vale do Peruaçu, município de Januária, no norte do estado de Minas Gerais, foram estudas através de técnicas de biologia molecular, com o intuito de compreender melhor a história evolutiva destas espécies nas regiões das Terras Baixas da América do Sul e sua relação com outras amostras destas espécies de diferentes regiões das Américas.

Um segmento do gene nuclear $A d h 2$ foi amplificado e sequenciado a partir de extratos das amostras de milho, enquanto, no caso das amostras de feijão, dois foram os alvos genéticos, que amplificaram e sequenciaram duas regiões distintas do gene nuclear Phs. O mesmo procedimento foi realizado com as amostras modernas destas duas espécies. 
No caso do milho, três padrões/ grupos principais de alelos do gene Adh2 foram encontrados, baseado principalmente em regiões de microsatélites. Os três padrões estão presentes na região de origem do milho, na América Central e também foram observados na América do Sul, mas nesta última região, eles não estão homogeneamente distribuídos. Um primeiro tipo, aparentemente o mais simples, primitivo, está presente praticamente apenas na região da Cordilheira dos Andes. Os outros dois tipos se fazem mais presente na região das terras baixas da América do Sul, sendo que um deles se encontra somente na parte leste do continente, ao longo das bacias hidrográficas dos rios São Francisco e Paraná-Paraguai.

Este padrão terras altas/ terras baixas é um fenômeno antigo, como demonstram as amostras arqueológicas e sugere a ocorrência de duas levas principais e independentes de entrada, difusão de raças/ etnovariedade distintas de milho no passado, na América do Sul. Estas levas devem ter ocorrido por volta de 5.000 anos atrás para a primeira delas e por volta de 2.000 anos para a segunda. Uma terceira, mais recente, ainda é possível de ter ocorrido, seguindo mais ou menos o caminho da segunda, mas ficando mais confinada a região leste do Brasil.

Estas levas só se explicam pela influência do homem, que foi o agente difusor desta planta, seja através de migrações, onde levou consigo amostras desta planta, seja por troca ou mesmo por conquistas. Os dados sugerem que existiu uma relativa integração humana na parte sul do continente, ligando culturalmente populações humanas desde o Chile até o Paraguai e Brasil, como é mostrado pelo compartilhamento de alelos de milho nestas áreas.

Vemos ainda que os tipos de milho da região dos Andes Centrais - Peru, historicamente tiveram pouca influência na formação dos genótipos de milho presentes na região das terras baixas, sendo que as amostras de milho encontradas em Januária apresentam uma relação muito maior e direta com materiais da América Central, do que dos Andes, indicando que, culturalmente, principalmente em termos de alimentação, as populações de Januária receberam uma influência maior de populações humanas das terras mais ao norte e não da região dos Andes Centrais. 
Este padrão perdura até os dias de hoje, fato este que deve ser o resultado do modelo de colonização européia no Novo Mundo, onde, de modo geral, a região das terras baixas do continente foi colonizada pelos portugueses e as terras altas pelos espanhóis, mantendo este relativo isolamento entre os habitantes das duas regiões, indicando que, aparentemente, as barreiras culturais humanas foram muito mais fortes, importantes e decisivas na origem, seleção e difusão dos gêneros animais e vegetais que o homem utilizava em seu dia a dia, do que as própria barreiras geográficas.

Já no caso do feijão, verificamos primeiramente que a amostra arqueológica se trata da espécie Phaseolus vulgaris e que o tipo básico genético da proteína Phaseolina presente na amostra de Januária é do tipo " $\alpha$ ” e não do tipo ' $\beta$ ”. De modo geral a distribuição dos alelos encontrados nas diferentes amostras segue um padrão geográfico, onde todos os alelos oriundos de amostras da região desde o México até o norte da América do Sul (Colômbia/ Equador/ norte do Peru), ficaram em um mesmo grupo, a que chamamos de grupo Norte, enquanto, no outro grupo de alelos, só estavam presentes alelos oriundos de amostras do Sul do Peru e da Argentina, e que chamamos de grupo Sul.

Aparentemente os alelos do grupo Norte são os mais antigos, indicando que a origem do feijão deve ter-se dado naquela região. Já as populações de feijão com alelos do grupo sul devem ter se originado a partir de populações do grupo Norte, posteriormente.

Os dados sugerem que o feijão deve ter tido apenas um centro de origem e todos os diferentes tipos de feijão hoje existentes evoluíram a partir de uma mesma população ancestral. Isto vai de encontro com algumas teorias que dizem que o feijão pode ter tido mais de um centro de origem, independentes.

A amostra de Januária apresentou 6 alelos distintos, sendo que destes, dois são exatamente iguais aos alelos do grupo do Norte, sendo os outros 4 alelos exclusivos. Destes 4 alelos exclusivos, dois são muito próximos à alelos do grupo do Norte e os outros são intermediários. A amostra não apresentou nenhum alelo exatamente igual ao encontrado em indivíduos do grupo Sul 
Isto sugere que, geneticamente, a amostra de Januária possui um maior grau de relação com alelos presentes em populações do grupo do Norte, mas também apresenta vestígios de um certo grau de contato com alelos mais relacionados a populações mais do centro sul andino.

De modo geral, esta amostra de feijão de Januária confirma os dados levantados com as amostras de milho, onde sugerem que as populações de Januária possuíam uma relação ou influência de materiais cultivados muito maior com amostras vindas da região da América Central e norte da América do Sul e muito pouco com amostras da região dos Andes Centrais, como Peru.

Observamos ainda que a diversidade genética interespecífica dentro do gene de feijão estudado é maior do que a observada dentro do gene estudado de milho.

Por último, este trabalho demonstra que amostras arqueológicas vegetais oriundas de regiões tropicais podem conter material genético ainda preservado e apto para estudos evolutivos e, em paralelo, para vislumbrarmos a história do próprio homem nas Américas. 


\section{EVOLUTIONARY-GENETICAL STUDIE OF MODERN AND ARCHAEOLOGICAL SAMPLES OF MAIZE (Zea mays mays, L.) AND BEANS (Phaseolus vulgaris, L.)}

Author: Fábio de Oliveira Freitas

Adviser: Prof. Dr. Gerhard Bandel

SUMMARY

Seven archaeological samples of maize Zea mays mays, Lineu), $620 \pm 60$ to $990 \pm 60$ years old and one sample of bean (Phaseolus vulgaris, Lineu), $301 \pm 39$ years old (based on $\mathrm{C}^{14}$ datation), were studied by biomolecular techniques to understand their historical origin. They were found in indigenous subterranean silos, from archaeological sites at Januária (Peruaçu Valley), state of Minas Gerais, Brazil.

A segment of the nuclear gene encoding alcohol dehydrogenase 2 (Adh2) was amplified and sequenced from extracts of the maize specimens. In the bean sample, two portions of the nuclear gene encoding the protein Phaseolin were used.

In maize, 3 main alele groups were observed for the Adh 2 previously know in the maize origin center in the Central America. In the South America, these groups have also been founded but presenting a characteristic geographical distribution. One of the aleles, considered the most primitive, occurs in the Andean highlands. The other two are present mainly in lowlands, one of them restrict to São Francisco and Paraná-Paraguai rivers basin, along the Atlantic coast.

These dates suggest that, historically, different maize varieties were introduced in South America, perhaps in two different periods and spread to distinct regions by migrating or trading human populations. The first introduction is estimated to have occurred about 5,000 years ago, and the second and possibly a third, about 3,000 years 
later. These introductions must be responsible for the high-/lowland distribution pattern, which maintains up to today. The European colonisation of the South America in the 15$16^{\text {th }}$ century kept this pattern. Portugal conquered the lowlands and Spain the highlands and they maintained a cultural and trade barrier for long time. However in the Southern part of South America there must have been some exchange, since aleles from lowlands were found in archaeological sites in highlands of Chile, and conversely, highland aleles were present in one modern indigenous sample from Paraguay. It should be mentioned that archaeological and modern aleles found in Peru are remarkably different from those of Brazil. This would mean that Brazilian indigenous populations must have been more influenced by Central America culture, rather than from that of Andean highlands.

In the case of Januária bean sample, identified as Phaseolus vulgaris, presents the basic genetic type of the Phaseolin of type $\alpha$. The alleles from modern samples from Mexico to Argentina, indicate a geographical distribution pattern. The alleles originated from Mexico to the Northern region of South America (Colombia, Ecuador and North of Peru) fall in the same group, what we called Northern alleles group, while those from Southern Peru to Argentina fall in another group, that we called Southern alleles group.

Apparently Northern group of alleles are older, pointing the corresponding region as the centre of the origin for Phaseolus vulgaris. Southern group of alleles must have been derived from those from the North. This confronts some theories suggesting that bean might have had more than one centre of origin, independently.

The Januária sample had six different alleles, two identical to the Northern group. Of the remaining four, two are very close to the Northern group, while the other two may be considered intermediary. No allele similar to the Southern group was found. The conclusion is that the bean sample from Januária is genetically closer to the Northern populations but has vestiges of contacts with populations from Centre and Southern Andes.

All put together, maize and beans populations from Januária seem to had a lager relation or influence of materials originating from the Central America and very little 
with those from Central Andes, as Peru. Also, a higher genetic diversity was observed within bean genes than maize.

Finally, this research demonstrated that plant archaeological samples from the Tropics may contain well preserved genetic material suitable for evolutionary studies and provide data to understand the life history of the Humanity in the Americas. 


\section{INTRODUÇÃO}

Era uma vez... Há mais ou menos 4,5 milhões de anos atrás, quando as primeiras espécies de plantas da América do Norte e América do Sul começaram a entrar em contato mais facilmente. Naquele momento, a formação do Istmo do Panamá estava sendo concretizada, servindo como uma ponte natural de terra ligando os dois continentes, antes isolados, permitindo o encontro/contato e colonização de novas regiões por diferentes espécies ${ }^{1}{ }^{1}$.

Devido principalmente às condições climáticas do globo, a transposição das espécies entre os territórios vizinhos foi, primeiramente, muito mais no sentido da América do Norte em direção à América do Sul do que o inverso, ou seja, espécies de clima temperado da América do Norte tiveram mais facilidade de encontrar ambientes com condições que pudessem colonizar e se estabelecer na América do Sul, enquanto as espécies tropicais já tiveram uma dificuldade maior neste sentido, segundo o mesmo pesquisador mensionado anteriormente.

Muito tempo depois, por volta de 18.000 anos atrás, ocorria o pico máximo de intensidade da ultima glaciação ocorrida no globo, onde a água congelada nos pólos fazia com que o nível dos oceanos se encontrasse 100 metros abaixo dos níveis atuais (Lahr, 1989).

Já por volta de 12.000 anos atrás a temperatura do globo já se encontrava mais elevada, derretendo parte da água que estava retida nos pólos em forma de gelo, aumentando assim o volume dos oceanos, o que culminaria com os níveis que encontramos atualmente (Lahr, 1989).

${ }^{1}$ Grahan, A. (Kent Universithy, UK) - comunicação pessoal, 2000 
Por volta desta última data, ou até mesmo anteriormente como pesquisadores tem aventado mais recentemente, o homem atravessava o Estreito de Bering, vindo da Ásia para a América do Norte e, seguindo para o sul, populações humanas atravessavam aquele mesmo Istmo do Panamá, e davam seus primeiros passos na América do Sul (Neves et al, 1989; Pena et al, 1989; Prous, 1989; Roosevelt, 1996).

Esta sua passagem trás consequiências muito grandes às demais espécies animais e principalmente vegetais que encontra, pois a sua capacidade de influenciar o ambiente, manipulá-lo, selecionar espécies, fomentar pressões evolutivas antes inexistentes sob determinadas plantas, faz com que determinadas espécies de plantas se modifiquem/ evoluam com velocidades diferentes ou mesmo em direções evolutivas diferentes do que possivelmente ocorreria, caso estivessem em condições naturais, sem a interferência do homem.

Após certo período do estabelecimento do homem nas Américas, há mais ou menos 8.000 anos atrás, uma série de espécies passaram a ser domesticadas ou semidomesticadas, muitas das quais são as bases das principais culturas de que nos alimentamos atualmente. Futuras espécies domesticadas como o milho, tomate, feijão, amendoim, mandioca, entre tantas outras, começavam a ser criadas, domesticadas a partir de seus ancestrais selvagens, pela influência humana (Harlan, 1971; Gepts \& Debouck, 1991).

Após milênios de isolamento, no ano de 1492 de nossa era, uma nova leva migratória humana tinha início, mas desta vez vindo pelo leste, atravessando o Oceano Atlântico, chegando nas ilhas da região das Antilhas e estabelecendo os primeiros contatos entre culturas humanas tão distintas.

Este novo contato seria estabelecido definitivamente no hemisfério Sul há 500 anos atrás, quando uma esquadra de caravelas e naus aportaram na costa de uma terra que viria a ser chamada de Brasil, no continente Sul Americano. Naquele momento, raças/ culturas humanas há muito tempo isoladas entraram novamente em contato e a história escrita deste contato começava a ser registrada. 
Até então, na região do Brasil, as histórias do passado destas populações nativas eram contadas oralmente, passadas de geração para geração, gravadas apenas na consciência destes seres humanos ou por grafismos toscos em rochas.

A ínfima diferença genética existente entre estes dois grandes grupos humanos era inversamente proporcional à imensa diferença cultural existente, a qual foi a responsável pelo quase aniquilamento dos antigos moradores do continente americano.

Como a história escrita começou a ser descrita pelos colonizadores e não pelos colonizados, toda a visão que possuímos desta época é a partir de mentes humanas recheadas com culturas européias, com conhecimentos e interesses particulares, normalmente interessados em explorar riquezas aqui encontradas e sem se preocupar em entender e descrever com o rigor da verdade as culturas que ia dominando, dilapidando e, em muitos casos, extinguindo.

Deste modo, mesmo havendo algumas raras exceções a este acontecimento, o fato é que pouco sabemos sobre a maioria das culturas indígenas que habitavam as terras baixas do continente sul-americano, quando da chegada dos primeiros europeus, e muito desta história morreu silenciosamente, sem ter tido a chance de ser registrada e, somente mais recentemente começamos a prestar mais atenção a estas culturas e tentar entendêlas como realmente são e como é seu modo de vida, o que plantam e como; de que forma preparam seus alimentos; o que utilizam da mata; seus remédios,.....mesmo que em alguns destes casos o interesse ainda seja mais econômico do que propriamente humano.

Se a verdade é que pouco sabemos sobre a vida e costumes das populações indígenas nestes últimos 5 séculos, maior ainda é a incógnita que a cerca os fatos que ocorreram na época anterior a este contato.

Questões como quais populações humanas que foram as responsáveis pela domesticação das plantas cultivadas que os índios já possuíam quando da época do contato com os europeus; a onde estas foram domesticadas; quando; como foi a difusão destas plantas pelas diversas regiões das Américas; quem as difundiu; como eram as primeiras raças domesticadas e quais surgiram depois, aonde e quando; por onde as populações humanas migraram; o que levavam nestas andanças (plantas, animais, 
ferramentas,..); quais eram as culturas que mantinham contato entre si e o que trocavam, apenas citando alguns questionamentos entre tantos outros que podemos formular, possuem dificuldade de serem respondidas, sendo que algumas talvez fiquem para sempre sem resposta.

Hoje muitas das tribos indígenas sobreviventes já registram sua própria história, possuem mapas precisos de onde se localiza sua aldeia, adotaram o calendário, podendo dizer com precisão em que ano seus filhos nasceram e quando foi que ocorreu a ultima mudança/ migração de sua aldeia e de onde.

Entretanto o passado mais distante ele não sabe contar e se quisermos tentar esclarecer pontos deste passado remoto temos que dispor de diferentes ramos da ciência, através de metodologias que envolvem evidências obtidas a partir das próprias plantas, incluindo o material vivo (taxonomia experimental, ecologia, sistemas genéticos, padrões de variação, reconstrução genética) e material arqueológico (arqueobotânica, palinologia, paleobotânica), a atividade dos homens contemporâneos (língua, tradição oral, técnicas, nutrição) e o passado (história, arte, arqueologia, antropologia física) e outras fontes (geologia, hidrologia, etc.) (Harlan e de Wett, 1973).

Através destas ciências, pesquisadores tentam resgatar do passado evidências que contam um pouco sobre estas populações que aqui viviam e, aos poucos, pequenos fragmentos desta pré-história podem ser revividos, fragmento histórico este que tentaremos fomentar e abordar neste nosso trabalho, trazendo, talvez, um pouco mais de detalhes deste passado.

\section{OBJETIVOS}

Os objetivos deste trabalho são de tentar conhecer um pouco mais sobre a história de algumas plantas cultivadas pelas populações humanas do continente Americano, em particular o milho Zea mays L. e o feijão - Phaseolus vulgaris L., ambas espécies tendo sido domesticadas no Novo Mundo.

Utilizando amostras arqueológicas e modernas destas duas espécies, além de dados já disponíveis na literatura, realizamos uma investigação genética para tentar 
conhecer algumas caraterísticas das etnovariedades (variedades locais, normalmente ligadas a uma ou algumas culturas humanas que a tenham selecionadas) destas plantas que existiam no passado e compará-las com as do presente, verificando qual o grau de diferença genética-evolutiva existente entre as amostras modernas e arqueológicas através da identificação das transformações que determinados genes destas espécies sofreram durante a evolução das diversas raças/ etnovariedades destas plantas durante parte de sua evolução após terem sido domesticadas.

Com base nos dados genéticos levantados, procuramos determinar a origem do material que chegou ao Brasil nos tempos remotos, ou seja, propor as possíveis fontes de origem destas espécies cultivadas que eram utilizadas nas terras baixas da América do Sul, em especial na região de Januária, no Norte de Minas Gerais, de onde são as amostras arqueológicas que utilizamos neste trabalho e, deste modo tentar propor os possíveis caminhos terrestres por onde estas etnovariedades podem ter vindo. 


\section{REVISÃO BIBLIOGRÁFICA}

Esta revisão está dividida em diferentes tópicos, sendo essencialmente constituída por dois grandes blocos de assuntos ligados as culturas de milho e feijão, respectivamente. Cada um destes dois blocos contem subdivisões com assuntos relacionados a origem, domesticação, evolução e história destas duas culturas vegetais e que servem como base para quando formos discutir os nossos resultados obtidos com esta tese. A última seção, que faz uma revisão sobre trabalhos que utilizaram técnicas moleculares no estudo de amostras arqueológicas, é comum para ambas culturas.

\subsection{O gênero Zea - Lineu}

O milho pertence ao reino Plantae; divisão Anthophta; classe Monocotiledonae; ordem Poales; família Poaceae (Gramineae); gênero Zea; espécie Zea mays. O gênero Zea é composto por um grupo de gramíneas, algumas perenes e outras anuais, nativas do México e da América Central (Doebley, 1990).

O gênero inclui tanto a planta cultivada, o milho, como os parentes selvagens, conhecidos comumente pelo nome de teosinte. O milho é originado da América e, desse modo, só passou a ser conhecido pelos Europeus quando do retorno de Colombo à Europa, levando consigo milho encontrado em Cuba.

O Teosinte só passou a figurar entre as espécies reconhecidas pelos europeus em 1832, através de um botânico alemão, Schrader, denomeando aquela determinada planta de ciclo anual com o nome científico de Euchlaena mexicana. Em 1910, Hitchock descobre um outro parente desta planta, perene, a qual identificou como Euchlaena perennis (Doebley, 1990). 
Estas duas ultimas espécies possuem uma morfologia tão diferente em relação ao milho, principalmente em relação a inflorescência feminina, a espiga, que a princípio não pôde ser constatada a estreita correlação entre elas e o milho.

Durante o século 20, experimentos mostraram a relação estreita entre duas espécies, principalmente devido a testes que demonstravam a possibilidade de formação de híbridos férteis entre elas, fazendo com que as diferentes variedades de Teosinte fossem rebatizadas, trazendo-as todas para dentro do gênero Zea (Reeves \& Mangelsdorf, 1942).

Hoje as principais espécies e raças reconhecidas do gênero Zea são mostradas na tabela 1, segundo Iltis \& Doebley (1980):

Tabela 1. Distribuição e classificação das espécies e subespécies do Gênero Zea.

\begin{tabular}{|llllc|}
\hline \multicolumn{1}{|c}{ Seção } & \multicolumn{1}{c}{ Espécie } & \multicolumn{1}{c}{ Sub-espécie } & Hábito & Genoma \\
\hline Luxuriantes & Zea diploperennis & & Perene & $2 \mathrm{n}$ \\
& Zea perennis & & Perene & $4 \mathrm{n}$ \\
& Zea luxuriantes & & Anual & $2 \mathrm{n}$ \\
Zea & Zea mays & Zea mays mexicana & Anual & $2 \mathrm{n}$ \\
& & Zea mays parviglumis & Anual & $2 \mathrm{n}$ \\
& & Zea mays huehuetenangensis & Anual & $2 \mathrm{n}$ \\
& & Zea mays mays & Anual & $2 \mathrm{n}$ \\
\hline
\end{tabular}

\subsection{1 $\mathrm{O}$ ancestral do milho}

Durante o século 19, a origem e evolução do milho - Zea mays mays, se tornou um tópico de grande interesse entre os botânicos. O aspecto mais difícil para os cientistas era que o milho, diferentemente de outras espécies de cereais, como as existentes no Oriente Médio (trigo, centeio, aveia), aparentemente não se apresentava associado a nenhuma espécie selvagem a qual pudesse ser considerada como seu ancestral (Doebley, 1990). 
Esta situação proporcionou amplo tema para especulação, mas com pouco avanço na resolução do problema. Entretanto, o foco do debate mudou com a descoberta do teosinte e com a subsequente demonstração que híbridos entre alguns tipos de teosinte e milho são totalmente férteis, como demonstram os trabalhos de Schrader (1833) e Harshberger (1896), ambos autores sendo citados por Doebley (1990).

Isto permitiu que muitos autores incorporassem o teosinte em suas teorias sobre a origem do milho (Collins, 1921). Em 1939, Beadle argumenta que o teosinte é o ancestral direto do milho e diz que, devido ao fato destas duas plantas se cruzarem naturalmente e facilmente formarem híbridos férteis, isto era um indicativo que ambas as plantas pertenciam a uma mesma espécie, a qual estava em recente divergência genéticaevolutiva.

Enquanto a "teoria do teosinte" estava sendo formulada por Beadle, outros cientistas formulavam outras opiniões e teorias sobre a origem do milho (Saint-Hilaire, 1829 - citado por Doebley, 1990; Montgomery, 1906; Randolph, 1955; Weatherwax, 1955). As diversas teorias destes autores excluíam o teosinte como ancestral do milho e faziam crer que o milho derivava de um hipotético "milho selvagem", até então desconhecido, não identificado.

Um dos cientistas que mais apoiavam esta ultima visão é Mangelsdorf (Mangelsdorf \& Reeves, 1939; Mangelsdorf, 1974). Ele apontava para a grande diferença morfológica existente entre as espigas de milho e teosinte, diferença esta que, segundo ele, não poderia sustentar que o milho fosse uma divergência evolutiva direta, linear, a partir do teosinte, principalmente considerando-se o relativo curto tempo de domesticação do milho (menos de 10.000 anos), tempo este que seria insuficiente para promover o surgimento de uma nova espécie (raça) com mudanças morfológicas tão drásticas, segundo este autor.

Durante os últimos 60 anos, tanto a teoria do teosinte como o da existência de um hipotético milho selvagem, tiveram seus seguidores, com uma diversidade de opiniões e contribuições para cada uma das teorias, como Beadle, (1972; 1980); Benz, (1987); de Wet \& Harlan, (1972); Galinat (1983), Kato, (1984) e McClintock et al, (1984), 
suportando a primeira teoria, enquanto principalmente Mangelsdorf (1974; 1986), suportava a segunda.

Técnicas moleculares oferecem uma oportunidade de testar estas duas hipóteses. Caso a teoria do teosinte como ancestral esteja certa, é esperado que a seleção artificial feita pelos humanos sobre o teosinte, tenha afetado principalmente os loci genéticos que determinam as diferenças entre as espigas do milho e do teosinte, enquanto as diferenças entre os outros loci deve ser menor, mais homogênea, como por exemplo os responsáveis pelas isoenzimas (Doebley, 1990). Este estudo pode indicar primeiramente se o teosinte é o ancestral do milho e, além disto, qual das subespécies de teosinte o milho é mais próximo.

Segundo este ultimo autor, estes testes deram uma força muito grande a teoria do teosinte como ancestral, e apontaram para a subespécie Zea mays parviglumis como sendo a mais próxima isoenzimaticamente do milho. Isto sugere que o milho e a subespécie parviglumis compartilharam um mesmo ancestral mais recentemente, quando comparado com as outras subespécies de teosinte.

Entretanto, como as subespécies parviglumis e mexicana são muito próximas e como determinadas características da segunda, como local de ocorrência, que discutiremos a seguir, sugerem o maior parentesco do milho com a subespécie mexicana, ainda não está totalmente esclarecida qual a verdadeira contribuição de uma ou outra subespécie na origem do milho.

\subsubsection{Geografia da domesticação do milho}

Acredita-se que a região de origem das primeiras plantas de milho ocorre na região centro-sul do México.

Nesta região são encontradas populações naturais das subespécies do milho, principalmente as duas subespécies mencionadas acima, que são as mais próximas do milho e, por este motivo, iremos nos ater mais a relacionar características destas duas sub-espécies, que podem nos ajudar a entender como ocorreu a dinâmica evolutiva da origem do milho. 
A subespécie Zea mays mexicana ocorre em regiões com altitudes que variam entre 1800 e 2500 metros de altura, nas planícies e vales da região central e norte do México. A pluviosidade destas regiões varia entre 500 a $1000 \mathrm{~mm}$ de chuva anual, tendo ainda uma temperatura média anual entre 15 e $20^{\circ} \mathrm{C}$.

Já a subespécie Zea mays parviglumis ocorre em altitudes mais baixas, entre 400 e 1700 metros, principalmente no topo dos morros nos vales dos rios, na região oeste e sul do México, onde a precipitação anual é da ordem de 1250 a 2000 mm de chuva, com a temperatura média anual entre 20 a $25^{\circ} \mathrm{C}$.

A simples comparação entre as características do habitat destas duas sub-espécies mostra que cada uma delas está melhor adaptada a um distinto ambiente e, comparando estas características com o milho, pode-se ter indícios do grau de influência de cada uma na origem das diferentes raças desta planta cultivada.

Atualmente encontramos plantações de milho espalhadas por todas três Américas, atingindo latitudes elevadas nos dois hemisférios e sendo encontradas desde o nível do mar até altas altitude, o que demonstra que o milho deve possuir uma alta diversidade genética para poder ocupar uma gama de ambientes tão distintos.

Ao longo do processo de domesticação do milho e mesmo após o estabelecimento desta como planta cultivada, o milho deve ter sofrido introgressão com seus parentes selvagens, aumentando assim a sua diversidade genética. Esta diversidade é uma das principais responsáveis pela presença desta planta em tão amplo território, juntamente com sua aceitação cultural e alimentar pelos habitantes destes territórios.

Dobley (1990) sugere que, atualmente, populações naturais da subespécie parviglumis possuem uma maior dificuldade de introgressão natural com milho devido as populações não serem simpátricas, não habitarem um mesmo ambiente. Já as populações naturais da subespécie mexicana ocorrem mais próximas aos campos de milho, podendo ocorrer introgressão mais facilmente.

Toda essa diversidade se explica, em parte, pela importância que esta planta teve e ainda tem como base alimentar da maioria das populações das Américas. Tratado como algo sagrado, o milho teve sua diversidade aumentada tanto pelos diferentes ambientes em que era plantado e selecionado, como devido aos diferentes usos que dele 
eram feitos, desde preparos de comidas, bebidas e até ornamentais, que variavam com as tradições culturais de cada população.

Outro ponto comentado em diversos trabalhos sobre a origem do milho é em relação a quantas vezes o milho foi domesticado, ou seja, se ele foi domesticado somente uma vez e, a partir desta planta original, todas as outras raças de milho surgiram ou se ele foi domesticado independentemente mais de uma vez, como sugerem diversos autores (McClintock, 1959; Mangelsdorf, 1974; Bird, 1980;; Kato, 1984).

Segundo Doebley (1990), as evidências moleculares apontam para uma única origem, sendo esta origem a partir de um parente geneticamente muito próximo do genoma encontrado atualmente dentro da subespécie Zea mays parviglumis. Fala ainda que, caso o milho tenha tido uma múltipla domesticação, ou seja diversas vezes, todas elas devem ter ocorrido a partir de populações de plantas desta subespécie, porque qualquer transformação de teosinte em milho deve ter envolvido uma série de improváveis mutações, como relatam Galinat (1983) e Iltis,(1987) e, teoricamente, é mais fácil de explicar que estas mutações que permitiram esta transformação de uma planta selvagem em domesticada tenham ocorrido apenas uma vez.

Discutiremos mais profundamente esta questão sobre a influência genética dos ancestrais do milho quando falarmos sobre a parte de vestígios arqueológicos e migrações humanas no passado, no capítulo de resultados e discussões deste trabalho.

Faz-se importante salientar que a história evolutiva é dinâmica e, portanto, algumas das características presentes atualmente tanto nos parentes do milho como no próprio milho, podem não ser as mesmas que existiam na época do início da domesticação do milho, há mais de 7000 anos atrás.

\subsection{3 "Migração" do milho}

Como era a primeira raça do milho? Que outras raças surgiram em seguida? Quando? Como? Quando e para onde ocorreu a primeira migração do milho com o homem? Quais as características desta planta da primeira migração? Quando e quantas raças diferentes foram trazidas para a América do Sul? E para o Brasil? Por quais vias? 
Onde se estabeleceram? Quando...?; Como.....? Onde....? Estas são apenas algumas das questões que acercam a história evolutiva desta espécie. Algumas delas possuem suas respostas já delineadas na literatura, outras estão sendo investigadas e algumas podem ficar para sempre silenciosas.

Os estudos desta natureza de questões se baseiam em dados e evidências coletados a partir das próprias plantas, incluindo o material vivo (taxonomia experimental, ecologia, sistemas genéticos, padrões de variação, reconstrução genética) e material arqueológico (arqueobotânica, palinologia, paleobotânica), a atividade dos homens contemporâneos (língua, tradição oral, técnicas, nutrição) e o passado (história, arte, arqueologia, antropologia física) e outras fontes (geologia, hidrologia, etc.) (Harlan e de Wett, 1973).

Neste trabalho nos ateremos as principais evidências existentes que discorrem sobre a(s) entrada(s) do milho na América do Sul e Brasil.

\subsubsection{O milho na América do Sul}

As primeiras evidências de milho na América do Sul vêm de amostras arqueológicas encontradas no Peru. Segundo Goodman (1978) as evidências sugerem que o milho tenha sido cultivado nesta região desde o ano 2.500 A.C.(Antes de Cristo).

Piperno (1978), utilizando amostras arqueológicas de fitólitos de milho, encontradas em diversos sítios arqueológicos do Panamá, sugere a ocorrência de duas levas distintas de difusão do milho para a América do Sul a partir da América Central.

Fitólitos são microestruturas minerais de sílica presentes em diversas partes de uma planta como folhas, sementes, brácteas, caule, entre outras. A planta absorve a sílica do solo e esta é depositada e mineralizada em diferentes células. Estes minerais se formam naturalmente dentro de tecidos vegetais e resistem melhor ao intemperismo, podendo ser preservados no solo, após a decomposição da planta. Sua forma é específica para cada espécie e, deste modo, ele pode ser usado como testemunha da ocorrência de determinada espécie no local. 
Deste modo, esta autora sugere que o milho estava presente no Panamá desde antes da fase ceramista daquela região, com vestígios de sua presença nos horizontes cronológicos entre 5.000 - 2.800 A.C.. É interessante notar que as amostras pertencentes a este primeiro período se encontram todas nas regiões de altas altitudes do Panamá, enquanto as amostras que se encontram nas regiões das terras baixas do Panamá, ao longo dos grandes rios, só apresentam vestígios de milho a partir do ano 1.000 A.C.

Portanto, ela sugere que por volta de 1.000 A.C., houve uma dramática mudança de orientação na cultura de subsistência e habitação da região, quando o milho passa a integrar a cultura das populações humanas adaptadas as terras baixas, ao longo das planícies de inundação fluvial dos principais rios daquele país, sendo difundido por populações culturalmente distintas daquelas populações humanas que habitavam as regiões de terras altas do Panamá

A hipótese de duas levas distintas de milho para a América do Sul é corroborada pelo trabalho de McClintock et al (1981). Em suas conclusões, os autores discutem que a chegada do milho na América do Sul deve ter ocorrido principalmente através de duas levas migratórias independentes (seja através de migrações humanas carregando este material, ou seja pela introdução de espécies e raças através de trocas, com um limitado deslocamento humano). Afirmam ainda que a maioria das raças tradicionais atuais existentes na América do Sul foram evoluções ocorridas a partir delas.

Neste trabalho, liderado pela famosa cientista Dr.a Barbara McClintock, ganhadora do prêmio Nobel através de seus trabalhos genéticos em milho, eles compararam diversas raças atuais de milho utilizadas por populações tradicionais das três Américas, empregando a técnica de morfologia comparada dos Knobs cromossômicos, visualizados nos núcleos das células através de microscopía ótica.

Knobs são regiões da cromatina (DNA) permanentemente condensadas existentes nos cromossomos do milho, com posições definidas e que são facilmente visualizados em células que se encontram em metáfase ou em paquíteno (AguiarPerecin, 1985) e, seu tamanho, posição ao longo do cromossomo, e em qual dos cromossomos eles se encontram nas células, varia dependendo da raça de milho em questão. Destes modo, raças que possuem padrões semelhantes de Knobs, devem ser 
mais relacionadas do que outras com um padrão diferente, como é o caso de raças que possuem uma concentração grande destes Knobs e que diferem de outras raças que praticamente não se encontram Knobs. Portanto, neste trabalho, os autores utilizaram análises de amostras atuais de milho para melhor compreender a evolução das diversas raças desta espécie no passado remoto.

Como a presença do milho se encontra ligada a presença do próprio homem, padrões culturais diferentes devem ter tido um papel fundamental na difusão e geração das raças de milho na América do Sul.

Dados arqueológicos mostram a existência de diversos grupos culturais que existiram ao longo da história do homem nas Américas e que estas culturas variaram ao longo do tempo, tanto sofrendo ou "fornecendo" sua influencia a outras culturas (.....).

Através da arqueologia podemos conhecer em parte como eram as diversas culturas humanas que habitavam as Américas e como suas culturas evoluíram. As diferenças culturais entre grupos humanos existentes no passado devem ter criado "barreiras" entre determinados grupos distintos, dificultando trocas e difusões culturais, impedindo a homogeneização tecnológica e alimentar dos diferentes grupos.

Isto ajuda a entender, por exemplo, o porque de grupos humanos que estavam relativamente próximos e que habitavam regiões geográficas e climáticas semelhantes não compartilhavam a mesma tecnologia, utensílios e raças de espécies vegetais (......).

O inverso também é verdadeiro, onde grupos que teoricamente teriam dificuldade de se comunicarem devido a barreiras geográficas, como desertos e altas montanhas, apresentarem padrões culturais semelhantes. Exemplo deste fato são os casos reportados entre populações que habitavam a região norte do Chile possuírem padrões semelhantes a populações das terras baixas da América do Sul, como aquelas que habitavam a planície do rio Paraná ou mesmo na costa Atlântica, no Brasil (Stewart, 1963; Neves et al, 1989) .

Portanto, a princípio, uma diferença cultural entre diferentes grupos humanos pode ter sido, em muitos momentos históricos, uma barreira maior do que as barreiras geográficas. 
Um exemplo disto é a região da Cordilheira dos Andes, que possui clima e relevo mais ou menos parecido de Norte a Sul, o que poderia comportar populações humanas com culturas semelhantes. Entretanto, diversos estudos sugerem que historicamente diferentes culturas humanas habitaram este local, populações estas tão distintas que os pesquisadores dividem esta região em partes, cada qual com um padrão cultural típico.

Algumas destas regiões culturais, como o extremo norte (Equador e Colombia) e a região sul (norte e centro do Chile e noroeste da Argentina), se apresentavam mais relacionadas às culturas que habitaram regiões completamente distintas daquelas, como a das florestas tropicais, situadas nas terras baixas do continente Sul Americano, do que com a região central dos Andes (Steward, 1963; Taylor et al, 1978; McClintock et al, 1981).

Isto ajuda a explicar, ainda, do porque de raças de milho plantadas por populações tradicionais atuais do norte do Chile serem geneticamente mais aparentadas as raças cultivadas na região do Brasil central e Paraguai, do que com raças de milho que crescem no Peru, como demostra o trabalho de Blumenschein, em (McClintock et al, 1981).

Deste modo, mesmo existindo aparentemente apenas um centro de domesticação, é possível determinar-se em muitas regiões quais eram as raças mais utilizadas, traçando um mapa geográfico e temporal da ocorrência de determinadas raças em uma dada região e época e como elas foram variando com o tempo (ou se foram sendo substituídas por outras ao longo da história; se ocorreu introdução de novas raças, se uma nova raça ali foi desenvolvida, quais foram abandonadas/ extintas, etc.).

Estes dados permitem que se conheça um pouco mais sobre a cultura das populações do passado, além de permitir que a história de contato/ troca entre as diferentes populações das Américas seja melhor conhecida. Ainda existem muitas dúvidas e lacunas cercando a história das maiorias das culturas humanas e vegetais, principalmente nas regiões das terras baixas da América do Sul, devido principalmente a existência de raros casos de conservação de material arqueológico em regiões tropicais úmidas, dificultando estudos desta natureza. 


\subsubsection{Milho em Sítios Arqueológicos do Brasil}

Ainda são escassos os estudos de amostras arqueológicas vegetais no Brasil, devido principalmente a dificuldade de preservação destas, fazendo com que poucas amostras estejam disponíveis para estudo.

Neste ponto, a região do Vale do Peruaçu, no município de Januária, na margem esquerda do rio São Francisco, no norte do estado de Minas Gerais, é singular e vêm revelando evidências e amostras da presença humana do passado e restos de vegetais utilizados por estas populações humanas que ali habitaram, desde pelo menos 10.000 anos atrás. Nesta região esqueletos humanos, ferramentas, utensílios e amostras alimentares vegetais foram preservados e estão permitindo que conheçamos um pouco a respeito do passado desta região e sua relação com outras partes do continente Americano (Junqueira \& Malta, 1981/82; Prous et al, 1984 ; Veloso e Resende, 1992; Freitas, 1996).

Geologicamente, a região, segundo Prous et al, (1984), está assentada no Cráton Sanfranciscano, formado por rochas sedimentares do Grupo Bambuí. Os desenhos rupestres mostram além de animais da região, usados na alimentação ou não, cenas antropomórficas, do dia a dia e representações de vegetais, como plantas de milho, palmeiras e tubérculos, bem definidos.

Prous (1991), chama a atenção para o fato de que representações vegetais na arte rupestre são muito raras no mundo todo, porém relativamente comuns nas grutas e abrigos dessa região de Minas, incluindo plantas cultivadas como o milho, aumentando ainda mais a importância destes sítios..

Porém, o que mais chama a atenção, são os restos vegetais conservados nestes abrigos. Estes restos estavam acondicionados em cestas de folhas de palmeira, palhas de milho e capim trançado, que estavam enterradas e, por este motivo receberam a denominação de silos. Alguns destes silos eram formados por uma esteira de tábua ligadas por cordas de embira, formando o fundo do silo. Dentro destes silos foram encontrados fragmentos de mandioca, coquinho guariroba e licuri, feijão, algodão, diversas sementes, tais como urucum, pimenta, umbu, anonáceas, fragmentos de frutos 
de cansação, pitomba, cabaça, folhas de fumo e uma grande quantidade de espigas de milho de diferentes formas, tamanhos e coloração de grãos.

Estes silos possuem dimensões que variam de 20 a $120 \mathrm{~cm}$ de diâmetro, por no máximo $70 \mathrm{~cm}$ de profundidade (Veloso e Resende, 1992). Todo este material se encontra em excelente estado de conservação, fato este devido a diversos fatores, como o clima da região, a própria proteção dos abrigos em que foram depositados os silos e, provavelmente devido aos cristais de Calcita $\left(\mathrm{CaCO}_{3}\right)$ encontrados no interior das amostras, que ali chegaram após terem sido solubilizados, pelo intemperismo, a partir da rocha do abrigo e, assim penetrado e recristalizado nas amostras, fazendo com que o $\mathrm{pH}$ do material tenha sido elevado, o que permite um aumento de proteção contra um maior ataque por microorganismos (Freitas \& Martins, 2000).

Estes achados são muito importantes, pois devem permitir que conheçamos o passado das populações que aqui existiram, como era sua cultura, o que plantavam, o que comiam, que instrumentos fabricavam, qual o nível de contato com outras populações de diferentes lugares.

De acordo com Prous (1986), alguns achados arqueológicos de milho sugerem que esta espécie era cultivada, em Minas Gerais, pelo menos desde 4.500 B.P. (antes do presente, tendo o ano de 1950 de nossa era como referência inicial para base de calculo).

Em relação ao milho aí encontrado, Bird et al (1991) classificou-o como pertencente à raça Entrelaçado. Este é o nome que foi dado em português à raça "Interlocked' por Brieger et al. (1958), segundo Paterniani e Goodman (1977), a qual possui endosperma farináceo e aleurona de coloração roxa escura e clara, muito semelhante aos milhos atualmente cultivados pelos Xavantes (Brieger et al, 1958). Esta raça agrupa várias populações pertencentes à Bacia Amazônica, com exceção das populações de Cateto Nortista, sendo encontrada também no Peru e Bolívia, indicando uma vasta e contínua área de ocorrência.

A origem deste raça de milho, segundo Brieger et al (1958), é um mistério, mas ele sugere que este material é muito antigo, tendo surgido por seleção, a qual foi direcionada para grande número de fileiras e para o aumento do comprimento da espiga. Eles acreditam também que a característica dos grãos entrelaçados é contemporâneo das 
primeiras raças de milho domesticado. Esta raça é definida como sendo uma raça adaptada a baixas altitudes.

O primeiro estudo de análise de exemplares de milho arqueológico de sítios préhistóricos do norte e nordeste de Minas Gerais, foi realizado por Bird et al (1991). Os espécimes mais antigos encontrados, localizavam-se em horizonte cronológico entre 4.000 e 1.000 B.P.

Os exemplares de milho examinados foram agrupados por esses pesquisadores em quatro tipos principais: Entrelaçado Amazônico, Moroti-Gamba, Farináceo das Terras Baixas Tropicais e um grupo não identificado.

Além desta região, há relatos de milho arqueológico escavados em outras regiões do Brasil. Em Goiás, nos vales do afluente do rio Paranaíba, existem alguns abrigos onde foram encontrados entre outras coisas sepultamentos com restos alimentares e entre estes o milho. Do mesmo modo foram encontradas oferendas aos mortos no Rio Grande do Sul, onde o milho e a cabaça estão presentes. Neste último local, o milho se encontra em uma camada cronológica situada entre os anos de 140 e 1790 A.D. (Anno Dommini, depois de Cristo) (Prous, 1992). Milho e cabaça também são descritos por Roosevelt (1996) em cavernas em Monte Alegre, PA, onde a pesquisadora identifica o milho como pertencente à raça Coroico, que é a raça Entrelaçado. Temos ainda relatos de milho em Santa Catarina (impressão da espiga em cerâmica), Ilha de Marajó e, mais recentemente, em diversos quilombos espalhados pelo Brasil (Prous, 1992).

\subsubsection{O gênero Phaseolus - Lineu}

O gênero do feijão, Phaseolus, pertencente à subtribo Phaseolinae, tribo Phaseoleae, subfamília Papilionoideae e família das Leguminosae, é composto por mais ou menos 55 espécies, (Debouck, 1991).

Dentre as 55 espécies deste gênero, 5 foram domesticadas pelo homem, que são: Ph. vulgaris; Ph. lunatus; Ph. coccineus; Ph. acutifolius; Ph. polyanthus (Debouck, 1986). 
A origem evolutiva do gênero Phaseolus e sua diversificação primária ocorreu nas Américas (Vavilov, 1931, citado por Debouck, 1991), mas localizar um centro de origem definitivo para ele não é algo fácil (Harlan, 1971), como veremos a seguir.

\subsubsection{Local de origem do feijão}

Neste trabalho nos ateremos a descrever apenas a espécie $P h$. vulgaris, pois foi a espécie com que diretamente trabalhamos.

Atualmente esta espécie é encontrada em regiões que abrangem desde $52^{\circ}$ de latitude norte, se estendendo até a latitude de $32^{\circ}$ sul, habitando desde áreas ao nível do mar até 3.000 metros de altitude (Debouck, 1991).

A aceitação da origem americana do feijão ocorreu apenas no final do século XIX, baseado primeiramente em observações feitas através de amostras arqueológicas encontradas primeiramente no Peru e, posteriormente no sudoeste dos EUA (Gepts \& Debouck, 1991), o que vinha de encontro com as teorias antes aceitas de uma origem Asiática, como proposto, por exemplo, por Linnaeus, em 1753, este último citado pelos autores mencionados anteriormente.

Atualmente existe um grande número de amostras arqueológicas de feijão encontradas desde o sudoeste dos EUA, passando pela América Central e continuando pela região Andina da América do Sul até o centro norte da Argentina e Chile, com idades que chegam até quase 10.000 anos (Gepts \& Debouck, 1991).

Ainda segundo estes mesmos autores, todas estes achados arqueológicos possuem duas características em comum, a primeira que todas foram encontradas em regiões secas, tanto nos Andes como na América Central, além de todas elas serem restos de plantas de feijão já totalmente domesticadas, sem traços de características do ancestral selvagem. Como o feijão normalmente cresce em regiões mais úmidas, é provável que ele tenha sido domesticado em regiões com uma umidade maior e depois introduzido nestas regiões mais secas, o que explicaria a ausência de material selvagem e de transição entre os restos arqueológicos, além de sugerir que esta espécie pode ter 
sido domesticada há ainda mais tempo do que os 8.000 - 10.000 anos atrás atualmente aceito (Gepts \& Debouck, 1991).

Populações de feijão selvagem começaram a ser descritas e estudadas apenas a partir da metade do século XX e três aspectos destas populações selvagens são de particular relevância na discussão do processo de domesticação do feijão, que são: as características morfológicas destas populações selvagens; onde se encontram, ou seja, qual é a distribuição geográfica destas populações selvagens e qual é a relação genética existente entre as plantas selvagens e as plantas domesticadas (Gepts \& Debouck, 1991).

Populações selvagens de feijão crescem atualmente desde o norte do México até o norte da Argentina, em altitudes que variam entre 500 até 2.000 metros acima do nível do mar, com precipitação entre 500 a $1800 \mathrm{~mm}$ de chuva, não sendo encontrado naturalmente em regiões do Brasil (Debouck, 1986).

Em relação ao México, estas populações selvagens se encontram na parte centro oeste desse País, enquanto na América do Sul, estão localizadas ao longo da parte leste da Cordilheira dos Andes (Gepts et al, 1986).

Como vemos, populações selvagens de feijão estavam disponíveis naturalmente aos seres humanos primitivos em uma ampla área de distribuição geográfica e, portanto, havia a possibilidade delas serem domesticadas em diferentes regiões independentemente, como aparentemente foi, como veremos a seguir.

\subsubsection{Múltiplos centros de origem do feijão - Evidências}

Baseado em evidências de natureza morfológica (como tamanho e forma de sementes) e molecular (RFLP; Phaseolina; Lectina), estudos estão sendo conduzidos com o intuito de se identificar o(s) local(ais) de origem do feijão.

Pesquisas moleculares tendo como alvo o gene $P h s$, que codifica a proteína Phaseolina são atualmente uma das melhores ferramentas que ilustram esta questão. Esta proteína faz parte do material de reserva das sementes de feijão e apresenta uma relativa diversidade, onde pesquisadores já puderam identificar pelo menos 10 tipos de 
alelos diferentes desta proteína encontrados em diferentes acessos de amostras de cultivares de feijão - Ph. vulgaris e de parentes selvagens deste (Gepts, 1990).

Estudos conduzidos de extratos desta proteína corrido em gel de agarose sob corrente elétrica, mostraram diferentes padrões desta proteína, dependendo do tipo da amostra utilizada.

Existe uma alta correlação entre o tipo desta proteína e o local de origem dos materiais, tanto para materiais selvagens como domesticado, como mostrado na tabela 2 , a seguir.

Tabela 2. Tipo de phaseolina encontrada em populações de feijão selvagem e domesticado e sua origem geográfica (adaptado de Gepts \& Debouck, 1991).

\begin{tabular}{|c|c|c|}
\hline \multirow[t]{2}{*}{ Região } & \multicolumn{2}{|c|}{ Tipo de Phaseolina } \\
\hline & Material selvagem & Material domesticado \\
\hline América Central e México & "S"; "M" & “S” (92\%); "T" (8\%) \\
\hline Colômbia & "B"; “CH” & "S" (64\%) "T" (26\%) "C" (7\%) "B" (3\%) \\
\hline Andes (exceto a Colômbia) & "T" & "T" (50\%) "S" (17\%) "A" (1\%) "H" (1\%) \\
\hline
\end{tabular}

Como podemos ver pela tabela acima, a phaseolina do tipo " $\mathrm{S}$ " é mais comum em populações de feijão do México, enquanto a do tipo "T" é mais abundante na região Andina ao sul do Peru.

Outros tipos ainda são encontrados e são batizados como os tipo "C” , “CH”, entre outros. Os dados mais recentes sugerem que o cultivares de feijões atuais são o resultado de múltiplos eventos de domesticação, possuindo dois centros primários, localizados um na América Central e o outro no sul dos Andes (sul do Peru - Bolívia norte Argentina). Um terceiro centro ainda é sugerido na região da Colômbia (Debouck, 1986; Gepts, 1990; Gepts \& Debouck, 1991; Debouck et al, 1993).

No caso do tamanho das sementes, as variedades com sementes pequenas são mais relacionadas as regiões da América Central, enquanto aquelas que apresentam as sementes maiores pertencem normalmente a região Andina (Gepts \& Debouck, 1991).

Segundo estes mesmos autores, os tipos de feijão que foram mais disseminados na região das terras baixas da América do Sul, caso do Brasil, foram dos tipos da 
América Central, introduzidos via nordeste do Brasil, enquanto os tipos Andinos se encontram mais disseminados na África e Europa.

Debouck (comunicação pessoal) ainda diz que algumas variedades andinas de feijão devem ter sido disseminados no Brasil a partir do sul da Bolívia, via Paraguai, Santa Catarina, Paraná, São Paulo, chegando inclusive a Minas Gerais.

\subsubsection{O período colonial brasileiro e o feijão}

Os autores quinhentistas que descreveram o Brasil do início da colonização, mencionam os feijões e favas como componentes da alimentação indígena (Cascudo, 1983). Segundo este mesmo autor, a Europa só veio a conhecer o feijão por volta de 1540.

Ainda, segundo Cascudo (1983), o colonizador português não se tornou, a princípio, grande admirador do feijão, continuando a se alimentar basicamente com comidas típicas de sua terra natal, como comprovam documentos administrativos de gêneros alimentícios oriundos dos séculos XVI e XVII. O feijão passa a ter uma maior aceitação pelo imigrante Europeu durante a expansão do gado que ocorreu como forma de colonizar o interior do nordeste, a partir da metade do século XVII.

\subsection{As bandeiras de entrada no sertão nordestino, o rio São Francisco e Januária}

A colonização do Nordeste teve muitas particularidades. Como havia uma preocupação de ocupação francesa no norte do nordeste, Portugal incentivou a colonização dos imigrantes portugueses para aquela região, deixando a exploração do rio São Francisco para depois (Rego, 1945).

A foz do rio São Francisco não oferecia boas condições de abrigo aos navios e nem uma localização adequada aos estabelecimentos coloniais, o que fez com que os portugueses desprezassem este local inicialmente e se instalassem mais ao sul, na baía de Todos os Santos, um dos melhores portos da costa e onde tinham situação admirável sob o ponto de vista da defesa (Rego, 1945). 
As expedições de entrada no rio São Francisco a partir de sua foz, lideradas pelos nortistas, foi lenta e morosa, com muitos intervalos entre as expedições, permitindo que muitas partes do alto e médio São Francisco fossem primeiro alcançadas pelos paulistas, seguindo o sentido contrário, a partir das nascentes e afluentes deste rio (Lins, 1983).

O primeiro grande obstáculo que dificultava a subida do rio a partir de sua foz era a cachoeira de Paulo Afonso, a $330 \mathrm{Km}$ da costa. A cidade de Januária, à qual relegaremos mais importância neste trabalho, já que parte do material que estudamos provem de lá, como abordaremos mais a frente, se encontra a $550 \mathrm{Km}$ a partir da nascente do rio e a $1800 \mathrm{Km}$ de sua foz.

As primeiras bandeiras encontraram o interior do Vale do São Francisco sendo ocupado por tribos de língua Gê, como os Amoipiras, Massacarás, Pontás e Aracujás, os quais, segundo Lins (1983) haviam sido anteriormente expulsos do litoral pelos Tupis. Estes últimos serviram como guias para os bandeirantes e é por este motivo que muitas das regiões e acidentes geográficos receberam nomes de origem Tupi.

As bandeiras que haviam começado de maneira mais constante no início do século XVII, foram logo interrompidas devido a invasão holandesa em Pernambuco, atrasando mais uma vez a colonização do São Francisco

Devido a dificuldade de adentrar no sertão nordestino subindo diretamente pelo rio São Francisco, seja pela presença de acidentes geográficos, como a cachoeira de Paulo Afonso, seja pela presença de tribos indígenas na região que lutavam contra o avanço das bandeiras, diversas bandeiras tentaram caminhos alternativos para adentrar pelo sertão, tanto pelo São Francisco como por outras rota. Entre elas temos, segundo Vasconcelos(1974):

- A bandeira de Tomé de Souza entre 1553/4, compondo a primeira tentativa; a expedição de Martins de Carvalho em 1570, através do rio São Mateus, no Espirito Santo; logo depois, em 1573, Sebastião Fernandes Tourinho começa sua entrada pelo rio Doce, rumando depois por terra em direção norte, chegando ao Vale do Jequitinhonha e retornando pelo Rio Prado, na Bahia. 
- Em 1597, Afonso Sardinha atinge a serra da Mantiqueira, nos arredores da atual região de Sapucaí, vindo a partir de São Paulo.

- Quando os holandeses invadem o Nordeste no início do século XVII, poucas haviam sido as investidas pelo Nordeste, sendo que as que adentraram mais partiram do Espirito Santo, mas nenhuma havia conseguido ir além da Serra do Espinhaço, até aquele momento.

- Em 1646, Felix Jaques, partindo do Rio de Janeiro, atravessa a serra da Mantiqueira e chega nas cabeçeiras do rio das Velhas e Doce.

- Em 1674, Fernão Dias atinge as proximidades da nascente do São Francisco, a partir do Sul.

Quando os primeiros europeus chegaram na região de Januária, na segunda metade do século XVII ${ }^{1}$, esta já possuía uma história de ocupação humana por povos indígenas que remontam de pelo menos 10.000 anos de idade, evidenciados por diversos vestígios arqueológicos encontrados na região no Vale do Peruaçu, no município de Januária , como já dissemos anteriormente (Prous et al, 1984).

Até este momento, nesta revisão bibliográfica, abordamos diversos assuntos, alguns inclusive podendo parecer um pouco fora do contexto, mas acreditamos serem essenciais devido a natureza dos materiais que trabalhamos, as técnicas utilizadas no trabalho e, por último devido aos resultados obtidos. Deste modo, gostaríamos apenas de abordar um último item nesta revisão, que se diz respeito a técnica utilizada na análise das amostras, cuja essência é comum tanto para o que realizamos com o milho como para com o feijão.

\footnotetext{
${ }^{1}$ Prous, A (UFMG- Belo Horizonte) - Comunicação pessoal, 2000.
} 


\subsection{Análise de Material Genético Extraído de Tecidos Arqueológicos}

Até recentemente, antes do aparecimento de técnicas de genética molecular no início dos anos 70, o estudo de filogenia das espécies era baseado quase que exclusivamente à medidas morfológicas dos indivíduos.

Através da morfologia comparada entre espécies atuais e mesmo de fósseis construiu-se toda uma teoria de evolução dos diferentes gêneros, famílias, reinos, ....enfim toda a árvore genealógica das espécies conhecidas.

Entretanto, com o passar do tempo e o aparecimento de novas técnicas após a redescoberta da genética, passaram a existir dúvidas se a arquitetura desta árvore estava certa, primeiro porque existem lacunas ainda não totalmente esclarecidas devido a falta de fósseis representativos de alguns grupos e, outro motivo é que, como esta classificação é baseada na morfologia, ou seja no fenótipo, pode haver erros de classificação, já que, devido aos fatores ambientais, genótipos diferentes podem estar apresentando fenótipos parecidos e vice-versa.

Entretanto, com a redescoberta da genética no início do século, certas dúvidas sobre o grau de parentesco entre determinadas espécies começaram a ser melhor elucidadas, devido ao uso de diversas técnicas, como citologia, imunología, entre outras, como é o caso de inúmeros trabalhos onde, através da comparação do número e tamanho dos cromossomos de diversas espécies, pôde-se elucidar diversas dúvidas sobre o grau de parentesco e o caminho evolutivo destas espécies. Mas nenhum avanço foi tão grande quanto ao obtido pelas técnicas moleculares, as quais permitiram que tivéssemos acesso a detalhes diretos sobre o material genético das espécies.

Técnicas como eletroforese de isoenzimas, RAPD, RFLP, sequenciamento, entre muitas outras, nos ajudam a mostrar quanto que uma espécie está distante da outra, podendo saber por exemplo quais nucleotídeos da sequência do DNA diferem entre as espécies, permitindo estimar, por exemplo, o número médio de mutações por período de tempo que ocorreram nestas duas espécies desde um ancestral comum.

Entretanto, mesmo com todo este avanço, muitas dúvidas continuavam, devido principalmente ao fato de que estas técnicas moleculares permitem o estudo e 
comparação entre material genético de espécies vivas, ou seja, é necessário que a espécie ainda exista hoje em dia, pois muitas das técnicas comparam produtos de genes que estão expressando, por exemplo isoenzimas.

Portanto, através destas técnicas, acreditava-se que as comparações entre espécies atuais com espécies extintas fosse impossível, devido ao fato das células deste material estarem mortas e assim o material genético estaria completamente degradado, devido a hidrólise, oxidação, radiações cósmicas entre outros fatores que o degradam rapidamente, assim que a célula entra em colapso e morre.

Este cenário se modificou quando estudos e técnicas recentes mostraram que é possível o resgate de informação genética de espécies já extintas, permitindo assim a comparação e esclarecimento de diversas dúvidas que existem.

Esta área permite o estudo de evolução no nível molecular sem que haja um limite de escala de tempo (Herrmann \& Hummel, 1994).

\subsubsection{Técnicas}

\subsubsection{Imunologia}

A primeira técnica utilizada em material arqueológico foi obtida através da extração de albumina do músculo de um mamute extinto, encontrado na Sibéria, congelado (Prager et al, 1980).

Neste estudo, os autores isolaram esta proteína e compararam com a mesma proteína extraída de elefante asiático e africano atuais, através de imunologia, ou seja, isolaram esta proteína, injetaram em coelhos e estudaram os antigenos produzidos por estes animais para cada uma das albuminas injetadas (anticorpos). $\mathrm{O}$ que perceberam era que todos possuíam uma sequência primária muito próxima, confirmando o parentesco entre eles. 


\subsubsection{Extração de material genético de tecidos não vivos}

Entretanto, foi somente em 1984 que surgiu o primeiro trabalho utilizando diretamente material genético arqueológico (Highuchi et al, 1984).

Estes autores conseguiram extrair material genético de células da pele de um Quagga, animal parente da zebra e que foi extinto no século XIX. Eles retiraram estas amostras de peles que se encontravam em museus e estavam muito bem conservadas e, isto, somado a pouca idade relativa do material, permitiu que ainda estivesse presente uma grande quantidade de material genético, fazendo com que análises genéticas fossem possíveis.

Entretanto, a grande limitação desta técnica é que para uma análise genética ser possível, existe a necessidade de termos uma grande quantidade repetida de material, o que necessitaria obtermos a mesma parte ou sequência genética de diversas células do organismo, ou seja, o material necessita estar muito bem conservado, para que seu material genético não esteja muito degradado e necessitamos de uma amostra relativamente grande, o que inviabiliza trabalharmos com muitas das amostras existentes, já que muito do material arqueológico disponível são pequenos fragmentos, cuja técnica iria consumir todo o material existente.

Esta limitação deixou de existir quando, em 1985 foi desenvolvida a técnica de PCR ou reação em cadeia da polimerase.

\subsubsection{PCR - Reação em Cadeia da Polimerase}

A técnica do PCR, desenvolvida em 1985, consiste basicamente em amplificar, fazer muitas cópias a partir de um único fragmento genético, produzindo assim uma quantidade suficiente de material genético possível de ser analisado.

A amplificação é feita utilizando dois oligodeoxinucleotídeos primers, cada qual com mais ou menos 25 bases de comprimento; uma DNA polimerase termoestável e os quatro desoxiribonucleotídeos trifosfatos. 
Através da manipulação da temperatura, as duas fitas do fragmento do DNA são separadas. Em seguida um dos primers se liga a uma das fitas enquanto o outro primer se liga a fita complementar. A polimerase em seguida monta o resto da sequência complementar das fitas, a partir de cada primer. Através de ciclos de aquecimento e resfriamento, este fragmento de material genético vai sendo multiplicado, clonado, em quantidade exponencial.

Esta técnica permitiu a análise de material genético de tecidos fósseis/ arqueológicos porque ela é capaz de, com o primer adequado, conseguir resgatar algum fragmento de material genético que ainda esteja presente na amostra, sem necessidade de que todo o material genético da célula esteja intacto. Com isto conseguimos fazer uma grande quantidade de cópias deste fragmento e compará-lo com fragmentos de material genético de espécies atuais ou não, bastando para isto apenas que se utilize os mesmos primers, deste modo, teoricamente, os fragmentos amplificados das diferentes amostras serão correlacionados.

A partir da amplificação do material, diversas técnicas moleculares podem ser usadas para o estudo em questão. Uma das mais usadas, pela sua precisão é o de sequenciamento, onde é determinada toda a sequência de nucleotídeos dos fragmentos, permitindo deste modo uma comparação evolutiva base a base, indicando quais foram as mutações, mudanças que ocorreram entre as diferentes espécies ao longo do tempo, naquele fragmento específico.

O material genético mais trabalhado pelos pesquisadores é o de mitocondrias, ribossomos e cloroplastos (para as plantas), pois estas organelas aparecem em grande número dentro da célula e, portanto, a chance de se encontrar uma sequência de fragmento ainda intacta é muito maior do que o DNA nuclear que é cópia única (Lawlor et al, 1991).

Um dos problemas desta técnica e que gerou muita discussão no início é a de que o PCR não distingue entre um material genético da amostra e o de algum outro contaminante. Desde que o primer se encaixe na sequência, a reação irá amplificar o material que ali estiver, podendo ser o da amostra ou de uma bactéria que esteja ali ou mesmo de um microorganismo que já estivesse presente no momento da morte do 
indivíduo, ou mesmo contaminações com DNA humano devido a manipulação (Lindahl, 1972; Lewin, 1994).

Portanto, deve-se tomar muito cuidado na manipulação do material e escolher os primers adequados para que se tenha certeza de estar amplificando o material desejado.

A seguir fazemos um breve resumo de alguns trabalhos que utilizaram material genético antigo, resgatando um pouco de informações a respeito do passado.

\subsubsection{Revisão de trabalhos com resgate e uso de material genético ancião}

Novamente, o primeiro trabalho que utilizou diretamente material genético foi o realizado por Higuchi e Wilson em 1984. Extraindo material genético de células da pele de um Quagga, animal que habitava a África e que foi extinto no século passado, eles conseguiram elucidar uma dúvida que era palco de uma longa discussão.

Existia a dúvida se, filogeneticamente, o Quagga é mais correlacionado com o cavalo ou com as zebras. Os autores retiraram DNAmt (mitocondreal) de amostras de peles que se encontravam em museus e compararam com amostras de DNAmt de cavalo, zebras e asnos.

Através de mapas de restrição, eles conseguiram constatar o grau de divergência entre cada uma das espécies analisadas, vendo a porcentagem do número de substituições relativas de bases, comparadas uma a uma. Através deste estudo, o Quagga foi considerado como tendo o grau de parentesco maior com as zebras (Higuchi et al, 1987; Pääbo et al, 1989).

Logo após este trabalho, outro foi publicado, onde relatava o sucesso de extração de sequência repetitivas de DNA de uma múmia egípcia de 2.400 anos de idade, usando uma sonda contendo sequências "Alu" repetidas, mostrando que DNA mais antigo poderia ser preservado e, além disto, mostrando que não somente o DNA mitocondrial, mas também o nuclear era passível de uso (Pääbo et al, 1989; Lawlor et al, 1991).

Ampliando o tempo de resgate, fato este possível com o surgimento do PCR, conseguiu-se obter sequências de material genético cada vez mais antigo. Primeiramente 
foi o relato do estudo de DNA mitocondrial de células de cérebro humano de 7.000 anos preservados em sítios arqueológicos na Flórida, EUA (Pääbo et al, 1988).

Estas células estavam aderidas em restos de esqueletos excelentemente preservados devido as condições anaeróbicas e neutras nas regiões alagadas de turfeiras desta área.

Em seguida, o mesmo autor relata a manipulação de material genético de um bicho preguiça gigante de 13.000 anos.

A revelação de extração e amplificação, via PCR, de material genético de células de músculo de um mamute preservado no gelo há 40.000 anos, aumentou ainda mais a expectativa de montagem exata de filogenia das espécies (Herrmann \& Hummel, 1994).

Entretanto, foi em 1990 que surgiu a mais extravagante revelação, onde Edward Golenberg e seus colegas afirmavam terem isolado fragmentos de DNA de folhas de magnólia de 17 milhões de anos, encontradas em um depósito sedimentar em um lago em Idaho (Golenberg et al, 1990; Lewin, 1994).

Neste trabalho, os autores isolaram um fragmento de 820 pb, no qual existia uma parte do gen rbdL de cloroplasto. Amplificaram via PCR e compararam com a sequência deste gene em espécies atuais deste gênero, encontrando 17 substituições, onde somente 4 não ocorriam na primeira e segunda base. A partir disto pode-se fazer um dendograma relacionando este fóssil com as demais espécies analisadas.

Estes relatos foram seguidos em 1992 e 1993 pelo sucesso na extração de material genético de uma abelha e formiga de 25 milhões de anos e de um gorgulho de 120 milhões de anos, todos estes naturalmente preservados em âmbar (Cano et al, 1993; Lewin, 1994).

Um trabalho realizado por pesquisadores brasileiros, foi a análise de 18 esqueletos, de diferentes sítios arqueológicos no Brasil, principalmente no estado do Pará, e que se encontram no Museu Paraense Emílio Goeldi (Ribeiro dos Santos et al, 1996).

Estes esqueletos possuem uma idade que varia de 500 anos até alguns com 4.000 anos de idade. Neste trabalho as autoras sequênciaram um fragmento mitocondrial de 
$354 \mathrm{pb}$, encontrando 13 "haplotypes" , definidos pela variação na posição de 26 nucleotídeos.

Estas sequências foram comparadas com sequências encontradas na literatura para diversas amostras de populações nativas americanas e asiáticas/ mongólicas, indicando que 39\% dos "haplotypes" não haviam sido descritos ainda, indicando uma grande diversidade existente para aquelas populações que aqui habitavam e, mostrando que houve uma grande perda desta variabilidade, provavelmente devido a colonização.

Para todos estes estudos relatados acima, os fragmentos de material genético não são maiores que 800 pares de base, sendo a maioria ao redor de 200 pares de base. Este é um tamanho relativamente pequeno quando comparamos que em organismos vivos o material genético está na ordem de milhares de pares de base. Entretanto, mesmo estes pequenos pedacinhos podem trazer importantes informações para a identificação da espécie e sua comparação com as atuais.

O estudo de plantas cultivadas pelas populações antigas também é alvo de diversos trabalhos, onde o que se procura saber é por exemplo a que raça pertence tal amostra encontrada, deste modo saber as possíveis rotas migratórias das populações ao longo do tempo, quando e onde uma planta foi domesticada e por onde ela foi espalhada, disseminada, e quais as transformações por ela sofrida em sua evolução.

O estudo de sementes arqueológicas pode trazer muitas informações a respeito de como era a cultura de um determinado povo em uma dada época, sua relação com outras populações e como ela evoluiu ao longo do tempo.

Um destes trabalhos é o de Rollo (1985) e de Rollo et al (1991), o qual estuda ácidos nucleicos de sementes de milho pré-colombiano, fossilizados, datadas de 900 anos atrás, encontradas em um túmulo na costa do Peru.

Nesta análise, o autor usou como alvo do PCR, primers para amplificar sequências $\mathrm{Mu}$, que são elementos transponíveis encontrados em diversas formas (sequências) e quantidades dentro da espécie do milho - Zea mays mays, variando de raça para raça o tipo de elemento $\mathrm{Mu}$ e quantas vezes ele aparece repetido no genoma. 
Ele ampliou fragmentos de 90 a 200 bp e comparou com diversas raças de milho atuais, encontrando elementos do tipo Mu1, Mu4, Mu8 e possivelmente Mu5, permitindo um avanço no estudo na evolução da domesticação do milho.

Um terceiro trabalho que utilizou a técnica do DNA ancião em amostras de milho foi o de Goloubinoff et al(1993), onde o autor trabalhou com amostras modernas de milho, teosinte e Tripisacum, além de 3 amostras arqueológicas encontradas nos Andes, sendo duas no Peru, um na costa norte, de $4.700 \pm 500$ anos de idade e o segundo da região de Junín, a 3.700 metros de altitude com idade de $440 \pm 30$ anos, alem do sítio na costa norte do Chile com idade de $1500 \pm 50$ anos.

Os autores utilizaram como alvo de suas análises o gene Adh2 ou desidrogenase alcólica , que está localizado no cromossomo número 4 no milho. O estudo se restringiu a apenas uma pequena porção deste gene, com tamanho de $315 \pm 15$ nucleotideos de comprimento.

Os dados obtidos neste trabalho mostraram que a diversidade genética encontrada nas amostras arqueológicas é praticamente a mesma da encontrada nas modernas, indicando que não ocorreu variação no nível de diversidade genética do milho ao longo dos últimos 4.500 anos, contrariando trabalhos como o de Doebley et al (1986), que, através de isoenzimas em amostras modernas de milho e parentes selvagens indicavam que para o milho poder ter a diversidade atual era necessário que ele tivesse tido uma rápida taxa evolutiva desde a sua domesticação, o que não foi suportado pelo trabalho de Goloubinoff et al (1993).

Para este último autor, este fato pode ser explicado pela ocorrência de alguns possíveis cenários no passado. O primeiro seria que a diversidade do milho moderno é reflexo de "input" de genomas de teosinte, via repetidas introgressões. Outra possibilidade seria a domesticação do milho a partir de uma única, mas muito diversa população de teosinte ou, uma terceira, que as raças atuais de milho teriam sido originadas a partir de mais de um evento independente de domesticação, a partir de populações de teosinte geograficamente e geneticamente distintas. 
Todos estes trabalhos, além de outros que surgem a cada dia e em maior número, têm uma grande importância para a pesquisa científica.

Através destes trabalhos podemos elucidar melhor a história evolutiva das diversas espécies e qual é o grau de parentesco entre elas, montando a árvore genealógica de um grupo de organismos, raças, espécies, famílias,...

E é com o objetivo de entender um pouco mais profundamente sobre a relação e história de raças de milho e feijão arqueológicos encontrados no Brasil é que realizamos o presente trabalho. Nos capítulos seguintes descreveremos o trabalho em si, como foi realizado, os resultados obtidos e discutiremos como estes resultados se encaixam na história evolutiva destas espécies e com a do próprio homem. 


\section{MATERIAIS}

Dividiremos o material utilizado em duas partes, a primeira sendo composta por material arqueológico de milho e feijão, a segunda por acessos destas duas espécies obtidos em Bancos de Germoplasma e de coletas pessoais, representando raças e etnovariedades. Alguns dados de literatura já pré-existentes e que foram utilizados neste trabalho também são incluídos em cada um destes tópicos.

\subsection{Material Arqueológico}

Este material foi obtido através de escavações arqueológicas realizadas a partir do final dos anos 70, em antigos abrigos rochosos utilizados pelo homem pré-histórico no Vale do Peruaçu, na região de Januária, norte do Estado de Minas Gerais (Figura 1), pela equipe do Dr André Prous, do Museu de História Natural da Universidade Federal de Minas Gerais.

Ao longo deste Vale são encontrados muitos vestígios de que o homem esteve presente nesta região desde pelo menos 10.000 anos atrás, fato este revelado primeiro pela grande quantidade de pinturas rupestres presentes em muitos sítios arqueológicos da região e, depois, pelos materiais recuperados em escavações, como ferramentas de pedra, cerâmicas e vestígios vegetais, dos quais uma parte nos foi emprestada e é o material de nossa tese (Figuras 2 e 3).

O material vegetal é composto em sua maior parte de sabugos de milho - Zea mays mays, encontrando-se algumas amostras inteiras, com grãos e palha, mas a maioria sendo fragmentos do sabugo sem grãos. Uma boa quantidade de grãos soltos deste milho também nos foi fornecida além de fragmentos de carvão, de coquinho Guariroba - Syagrus oleracea e uma pequena quantidade de vagens e sementes de feijão - Phaseolus sp. Todo este material se encontra em excelente estado de conservação. 
Este material vegetal estava enterrado e acondicionado em uma espécie de "silo" subterrâneo de armazenagem, composto de uma cesta trançada por fibras de palmeiras, na qual o material vegetal era depositado, depois recoberto pela mesma trama de fibras, colocado em um buraco escavado no chão e, por cima desta cesta se colocava terra e cinza de fogueira, a qual diminui o ataque por insetos.

\subsubsection{Milho}

Trabalhamos com 20 amostras arqueológicas, sendo que destas, apenas 7 (sete) amostras arqueológicas de milho tiveram material genético suficiente para análise. As sete amostras utilizadas pertencem a 5 (cinco) silos diferentes, tendo estes silos sido encontrados em 3 (três) cavernas distintas, Lapa do Boquete, Lapa da Hora e Lapa do Caboclo, todos estes no Vale do Peruaçu (tabela 3).

Além destas amostras, dados de outras 3 (três) amostras arqueológicas já existentes na literatura (Goloubinoff et al, 1993), também foram utilizadas (tabela 3).

Tabela 3. Amostras arqueológicas de milho utilizadas nas análises; sigla de referência de campo; local em que as amostras foram encontradas e a parte do material que foi utilizado nas análises. Note que as amostras que trabalhamos diretamente se encontram no quadro superior e as obtidas na literatura são apresentadas no inferior.

\begin{tabular}{|llll|}
\hline Amostra & Local & Sigla & Material utilizado \\
\hline A2 & Boquete & BQT/92 silo4;N19 & Grão roxo \\
\hline A3 & Boquete & Boquete - sem referência & Sabugo \\
\hline A5 & Lapa Hora & Q.Deposito1; Amostra A & Palha \\
\hline A6 & Lapa Hora & Idem A5 & Sabugo \\
\hline A8 & Boquete & Idem A2 & Grão laranja \\
\hline A23 & Boquete & BQT/92 II méd. Rem. N19, 2972 & Grão queimado \\
\hline A34 & Caboclo & 1982, Setor F24, nível 1 méd. 2033 & Sabugo \\
\hline
\end{tabular}

\begin{tabular}{|lllc|}
\hline G6 & Hastorf -Peru & Goloubinoff et al, 1993 & - \\
\hline G7 & Tenney- Chile & Goloubinoff et al, 1993 & - \\
\hline G8 & Bonavia- Peru & Goloubinoff et al, 1993 & - \\
\hline
\end{tabular}


Figuras 1, 2 e 3

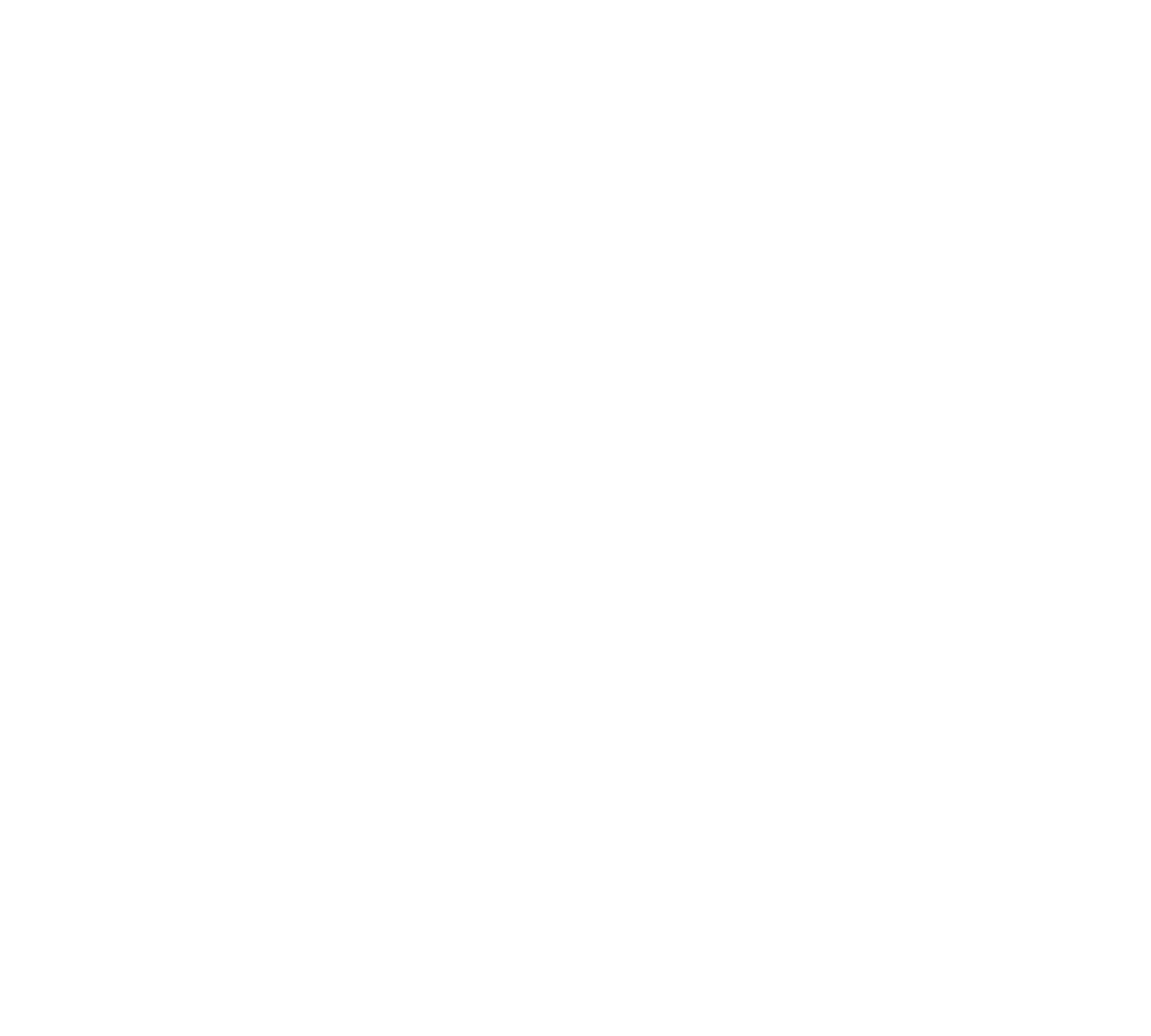




\subsubsection{Feijão}

As amostras arqueológicas de feijão eram compostas por três acessos encontrados na Lapa do Boquete, também em Januária, apresentadas na tabela 4. O material utilizado era composto por partes da vagem, para duas das amostras e de um grão, para a outra.

Tabela 4. Amostras arqueológicas de feijão utilizadas nas análises, sigla de referência de campo, local em que as amostras foram encontradas e a parte do material que foi utilizado nas análises.

\begin{tabular}{|llll|}
\hline Amostra & Local & Sigla & Material utilizado \\
\hline P1 & Boquete & BQT/2, P28, 1inf.A, 1809 & Vagem \\
\hline P2 & Boquete & BQT/89, J9, 0 inf., 1926 & Vagem \\
\hline P3 & Boquete & BQT/90, J(K) 8, 0 médio, 2754 & Grão \\
\hline
\end{tabular}

\subsection{Amostras modernas}

Para que tivéssemos um padrão de comparação nas análises com o material arqueológico, amostras modernas foram utilizadas, sendo compostas por raças comerciais e etnovariedades, que são melhor detalhadas a seguir, além de dados disponíveis na literatura.

\subsubsection{Milho}

Recebemos do Banco de Germoplasma do Centro Nacional de Pesquisa de Milho e Sorgo da EMBRAPA, em Sete Lagoas, MG, acessos de milho indígena e de cultivares comerciais antigos, todos coletados pelo Prof. F.G. Brieger e equipe, a partir da criação do Banco de Germoplasma Brasileiro de Milho em 1952, e cuja primeira sede foi o Departamento de Genética da E.S.A."Luíz de Queiroz”, em Piracicaba, SP. 
Nove acessos deste banco foram utilizados, além de outras duas amostras indígenas obtidas por coletas pessoais nas aldeias Waurá, do Parque Indígena do Xingu, MT e da aldeia Xavante de Água Branca, no município de Água Boa, MT.

Além destas, dados de outros 11 acessos disponíveis na literatura também foram utilizados e são apresentados na tabela 5 (Goloubinoff et al, 1993; Dennis et al,1985).

Tabela 5. Amostras modernas de milho utilizadas nas análises; fonte destas amostras e sua identificação; local em que as amostras foram coletadas e a parte que foi utilizado nas análises. As amostras que trabalhamos diretamente se encontram no quadro superior e as obtidas na literatura são apresentadas no inferior.

\begin{tabular}{|lllll|}
\hline Sigla & Variedade & Fonte & Localização & Material utilizado \\
\hline E1 & Wuara & Indígena- coleta pessoal & Brasil-MT & Grão \\
\hline E5 & Moroti & 7L - PR I*** & Brasil-PR & Grão \\
\hline E6 & Cateto & 7L - MA I*** & Brasil-MA & Grão \\
\hline E9 & Cristal & 7L - BA II*** & Brasil-BA & Grão \\
\hline E11 & Moroti-Guapi & 7L - PAG VI A*** & Paraguai & Grão \\
\hline E12 & Guarani & 7L - Complexo Guarani*** & Brasil-SP & Grão \\
\hline E13 & Cristal & 7L - MG III*** & Brasil-MG & Grão \\
\hline E14 & Caingang & 7L - SP XIII*** & Brasil-SP & Grão \\
\hline E15 & Cateto & 7L - BA I*** & Brasil-BA & Grão \\
\hline E21 & Cateto & 7L - SP VII*** & Brasil-SP & Grão \\
\hline E23 & Xavante & Indígena- coleta pessoal & Brasil-MT & Grão \\
\hline
\end{tabular}

\begin{tabular}{|llllc|}
\hline G1* & Northern Flint & USDA213760 & USA & - \\
\hline GBF* & Barkeley Fast & Freeling & USA & - \\
\hline G3* & Conflite Morocho & Bonavia & Peru & - \\
\hline G4* & Tabloncillo & USDA2835 & México & - \\
\hline G5* & Kculli-47 & Bonavia & Peru & - \\
\hline G9* & Z.mays mexicana & NS/SZ121 & Mexico & - \\
\hline G10* & Z.mays parviglumis & Dobley GB & Mexico & - \\
\hline G11* & Z.diploperenis & NS/SZ120 & Mexico & - \\
\hline G12* & Z.luxurians & Doebley HIG5 & Guatemala & - \\
\hline GTP* & Tripsacun pilosun & Doebley JD467 & - & - \\
\hline DBF** & Barkeley Flint & & - & - \\
\hline
\end{tabular}

* Goloubinoff et al, 1993; **Dennis et al,1985; *** Banco de Germoplasma de Sete Lagoas e sua respectiva sigla de identificação no banco. 


\subsubsection{Feijão}

As 10 amostras modernas de feijão (Phaseolus vulgaris) utilizadas neste estudo foram obtidas através de acessos mantidos pelo CIAT, da Colômbia, e estão listadas na tabela 6.

Tabela 6. Amostras modernas de feijão utilizadas nas análises, seu número de identificação no CIAT, local em que as amostras foram coletadas e a parte do material que foi utilizado nas análises.

\begin{tabular}{|llll|}
\hline Sigla & Número CIA T & \multicolumn{1}{c|}{ Localização } & Material utilizado \\
\hline F8 & G 19890 & Salta - Argentina & Grão \\
\hline F9 & G 19895 & Tucuman - Argentina & Grão \\
\hline F10 & G 23463 & Cundinamarca - Colômbia & Grão \\
\hline F11 & G 23589 & Apurimac - Peru & Grão \\
\hline F12 & G 24423 & Cundinamarca - Colômbia & Grão \\
\hline F13 & G 23583 & Piura - Peru & Grão \\
\hline F14 & G 23458 & Cuzcu - Peru & Grão \\
\hline F15 & G 23576 & Cuzcu - Peru & Grão \\
\hline F16 & G 11034 & Durango - México & Grão \\
\hline F17 & G 12935 & Jalisco - México & Grão \\
\hline
\end{tabular}




\section{MÉTODOS}

Os trabalhos de laboratório com as amostras modernas e arqueológicas de milho e feijão foram realizadas na UMIST (University of Manchester, Institute of Science and Technology), em Manchester - Inglaterra., no laboratório do Dr. Terrence Brown e sob supervisão do Dr. Robin Allabi, durante o ano de 1999.

O objetivo foi, a partir das amostras modernas e arqueológicas, conseguir obter sequiências de DNA amplificáveis das regiões dos genes alvos e compará-las. As etapas compreendidas neste processo são descritas a seguir.

\subsection{Extração e Amplificação de DNA}

\subsubsection{Extração de DNA}

A metodologia utilizada foi a técnica de extração por CTAB, com uma purificação secundária, como reportado em Allaby et al (1997).

Para cada amostra foram utilizados apenas 1 grão de milho e feijão, tanto para as amostras modernas como as arqueológicas. No caso de algumas amostras arqueológicas de milho, o material utilizado em alguns casos foi parte do sabugo ou da palha que recobre a espiga e, em duas amostras arqueológicas de feijão, utilizamos parte da vagem.

As amostras foram trituradas até serem reduzidas a uma fina "poeira", utilizandose cadinhos de cerâmica esterilizados. Esta etapa foi conduzida em câmara de fluxo contínuo de ar (evitar contaminação) e sem o uso de nitrogênio líquido (para tentar se evitar maiores danos ao material genético das amostras arqueológicas). 
Foi adicionado $1 \mathrm{ml}$ de buffer de extração - 2\% CTAB (100mM Tris-HCl, PH 8,$0 ; 20 \mathrm{mM}$ EDTA; $1,4 \mathrm{M} \mathrm{NaCl}$ ) às amostras trituradas e a solução foi incubada em banho-maria a $60^{\circ} \mathrm{C}$, por uma hora. (note que para as amostras arqueológicas este tempo de incubação foi de 3 horas).

Após este período centrifugamos as amostras em centrífuga a $14.000 \mathrm{rpm}$. Recolhemos a parte líquida para um novo tubo e descartamos o resto (para as amostras arqueológicas o descarte foi guardado e mantido em glicerol $20 \%$, para o caso de um estudo futuro). Fez-se então duas extrações com cloroformio (24 partes de cloroformio para 1 parte de alcool isoamil).

Adicionamos a solução final dois volumes do buffer de prescipitação - $1 \%$ CTAB (50mM Tris-HCl, PH 8,0; $10 \mathrm{mM}$ EDTA) e incubamos em $4^{\circ} \mathrm{C}$, por uma hora. (Novamente, no caso das amostras arqueológicas, estas foram deixadas durante a noite toda, nesta fase).

Em seguida centrifugamos novamente, descartamos o líquido, mantendo o precipitado. Ressuspendeu-se então em $50 \mu 1$ de TE (10mM Tris PH 8,0; 1mM EDTA PH 8,0).

5.1.2 Purificação do material extraído. (utilizado apenas para as amostras arqueológicas).

Esta fase foi utilizada nas amostras arqueológicas para tentar extrair qualquer substância existente na solução, após a extração (como restos de cloroformio, enzimas existentes no material, ....), que pudessem inibir a próxima etapa, a de amplificação de material via PCR.

Para cada amostra arqueológica extraída e mantida em TE, foi feito uma corrida de eletroforese em gel de 3\% de agarose e 1 X TBE $(10$ X TBE $=54 \mathrm{~g}$ Tris; 27,5g Ácido Bórico; 20ml 0,5M EDTA; completados em 500ml de água), submetida a uma corrente elétrica de $60 \mathrm{~V}$ por 1,5 horas.

Corou-se o gel com Brometo de Etídio e, sob luz ultra-violeta, cortamos a porção do gel que corresponde ao material genético. 
Fez-se então uma "eletrolution" para a retirada do material genético de dentro do gel e disponibilizá-lo em solução.

\subsection{3 "Eletrolution"}

A “eletrolution" consiste na migração do material genético que está dentro do gel de agarose para uma solução de TBE, devido a diferença de concentração de sais e através da corrente elétrica.

Tomou-se o gel, colocou-se em um saco de eletrolution, adicionou-se $450 \mu \mathrm{lde}$ 0,2 X TBE, as pontas deste saco foram fechadas, o fixamos em um tanque de eletroforese, então cobrimos com 0,2 X TBE e uma corrente elétrica de $100 \mathrm{~V}$ foi mantida durante 1,5 horas. Em seguida inverteu-se a corrente elétrica por apenas 4 minutos (para que o DNA aderido a parede do saco se soltasse) e retirou a solução, colocando-a em um tubo de ependorf de $1,5 \mathrm{ml}$.

Adicionou-se 2 volumes de $\mathrm{NaCl}$ à solução do ependorf e completamos com etanol $100 \%$. Manteve-se este preparo a $-20{ }^{\circ} \mathrm{C}$ durante a noite, centrifugando-a, então, em câmara fria por 15 minutos a 15.000rpm, no dia seguinte. Descartamos o sobrenadante e adicionamos etanol $70 \%$, este já pré-mantido a $-20^{\circ} \mathrm{C}$, fazendo em seguida um pequeno vortex no tubo e centrifugando-o novamente, descartando o sobrenadante. Em seguida secamos o restante da solução que ainda permanecia no ependorf em uma câmara de vácuo por 15 minutos e resuspendemos o precipitado em 50 $\mu 1$ de TE.

\subsubsection{Amplificação do material - via PCR (reação de polimerização em cadeia)}

O procedimento utilizando segue o padrão descrito por Pääbo et al (1988), sendo que utilizamos uma concentração de primer para cada amostra amplificada na ordem de $100 \mu \mathrm{M}$. Utilizamos para cada reação $5 \mu \mathrm{l}$ de amostra de material extraído, no caso de amostras modernas, e $10 \mu 1$, no caso das arqueológicas. 


\subsubsection{Primers utilizados}

Os genes alvos variaram para cada espécie, sendo que no milho o alvo foi uma região de 203 pb pertencente ao gene Adh2. Esta região foi amplificada, por PCR, usando os seguintes primers: "upstream" [5, CTGTGGATCCTCTCGTGT TCTTGGAGTGGT 3'], e [5' CTGTGGATCCTGCGGCTAGAGAGATGCAGCA 3'] “downstream".

No caso do feijão tivemos dois alvos distintos pertencentes a um mesmo gene, o gene Phs, que codifica a proteina Phaseolina (o motivo do uso de dois alvos no mesmo gene será melhor explicado no próximo capítulo).

Para a primeira região (PCR1), a seqüência alvo amplificada corresponde a um fragmento de tamanho que varia entre $245 \mathrm{pb}$ (pares de base), para amostras de phaseolina do tipo " $\beta$ " até 278 pb, para as do tipo " $\alpha$ ", ficando situado no final deste gene, abrangendo o $6^{\circ}$ exon deste gene e parte do 3 ' flank. Os primers utilizados foram: “upstream” [5' CTGTGGATCCACGTGTTGGGGCTTACGTTC 3'] e, "downstream" [5' CTGTGGATCCAAGAAGTGAGATGGAGCTCAG 3’].

Para a segunda região alvo deste gene (PCR2), a sequiência amplificada corresponde a um fragmento que varia entre 245 - $260 \mathrm{pb}$, abrangendo todo o $4^{\circ}$ exon deste gene e parte do início do $4^{\circ}$ intron. Os primers utilizados foram:

- “upstream” [5' CTGTGGATCCATAGAGCAAATTCGAGGAGATC 3'] e;

- “downstream” [5' CTGTGGATCCATGGTTTTTCTTTGTATTT 3'].

Os parâmetros utilizados nos ciclos do PCR para os três alvos foram:

$93,5^{\circ} \mathrm{C}-2 \min 30 \mathrm{~s}$;

$60^{\circ} \mathrm{C}-1 \mathrm{~min}, 74^{\circ} \mathrm{C}-1 \mathrm{~min}, 93,5^{\circ} \mathrm{C}-1 \mathrm{~min}$ (40 ciclos);

$60^{\circ} \mathrm{C}-1 \min , 74^{\circ} \mathrm{C}-8 \min$. 


\subsection{Gel de eletroforese}

Após o PCR foi realizada uma corrida de eletroforese em gel de agarose, com parte do produto do PCR. Uma das linhas de corrida era utilizada com um marcador, phago $\lambda$ (restrito com enzima de restrição pst1), para que pudéssemos verificar se havia amplificação positiva e com fragmentos de DNA com bandas do tamanho esperado do tamanho do fragmento.

Se positivo, corríamos o restante do produto em um novo gel (3\%), cortávamos somente a porção do gel com as bandas nas posições referentes ao tamanho esperado do fragmento genético alvo e, então, fazíamos uma nova "eletrolution”. Deste modo obtínhamos uma solução com uma concentração elevada de fragmentos amplificadosalvo, e limpos dos resíduos de produtos utilizados no PCR, o que permitia que passássemos a outra etapa.

\subsection{Clonagem do material genético amplificado.}

Ao final da etapa anterior tínhamos uma determinada quantidade de fragmentos de fita dupla de DNA, suficiente para que pudéssemos iniciar a etapa de clonagem, que é o passo final antes do sequenciamento.

Nesta etapa colocamos uma fita simples de DNA dentro de um vetor, no caso um vírus, o qual infecta uma bactéria, multiplicando-se exponencialmente, deste modo atingindo concentrações bastante elevadas do fragmento genético, de fita simples (necessário para o sequenciamento). Os passos desta etapa estão descritos a seguir:

\subsubsection{Digestão e junção da amostra de DNA com seu vetor}

Em uma das extremidades de cada primer existe uma sequência projetada para ser reconhecida por uma enzima de restrição, no nosso caso esta enzima era a Bam H I. Ao adicionarmos esta enzima à solução com os fragmentos genéticos, estes ficavam com 
as pontas "pegajosas", o que facilitava seu acoplamento/ junção, dentro do material genético do vetor, o vírus, este também tratado com a mesma enzima de restrição.

$\mathrm{O}$ vetor utilizado foi o vírus M13 mp18, tendo sido utilizado $0,02 \mu \mathrm{g}$ do vírus para cada amostra de DNA.

$7 \mu \mathrm{l}$ de DNA de cada amostra foram colocados junto com o montante de vírus acima descrito e estes mantidos a $45^{\circ} \mathrm{C}$ por 10 minutos e, imediatamente após isto, o tubo era mergulhados em gelo.

Adicionava-se então a enzima ligase a esta reação, juntamente com o buffer específico, e toda esta solução era mantida a $15^{\circ} \mathrm{C}$ durante a noite, ou no mínimo por 2 horas e 30 minutos. O objetivo desta etapa é obtermos o fragmento de DNA de fita simples dentro do vetor, o qual poderá, deste modo infectar a bactéria, na etapa chamada de transformação.

\subsubsection{Transformação}

A bactéria utilizada foi a Escherichia coli XL IB.

Esta bactéria foi crescida em um meio de cultura líquido LB, sob agitação leve, durante a noite, em sala mantida a $36^{\circ} \mathrm{C}$. Na manha seguinte, $0,5 \mathrm{ml}$ desta solução eram colocados em $50 \mathrm{ml}$ de um meio LB fresco e deixado para crescer sob agitação durante 3 horas e 15 minutos, também a $36^{\circ} \mathrm{C}$.

Após isto, toda esta solução era dividida em 2 tubos de centrífuga e centrifugadas por 10 minutos a $3.000 \mathrm{rpm}$, em centrifuga mantida a $4^{\circ} \mathrm{C}$.

O sobrenadante era descartado e o precipitado ressuspendido em $15 \mathrm{ml}$ de $0,05 \mathrm{M}$ $\mathrm{CaCl}_{2}$ (pré-mantido a $-20^{\circ} \mathrm{C}$ ), juntando-se o produto dos dois tubos em um só, e incubando em gelo durante 30 minutos. Nova centrifugação igual a anterior e o prescipitado era resuspendido novamente em $3 \mathrm{ml} \mathrm{de} \mathrm{CaCb}$. Este produto é conhecido como "competent cells". 
A etapa propriamente chamada de transformação é quando $300 \mu 1$ destas bactérias que preparamos são colocadas no tubo de ependorf juntamente com o vírus contendo o material genético da amostra estudada dentro.

Para o vírus entrar dentro da bactéria, mantivemos esta solução por no mínimo 30 minutos em gelo, depois colocamos em banho-maria a $42^{\circ} \mathrm{C}$ por 1 minuto e 30 segundos e novamente mergulhamos em gelo.

Feito isto, adicionamos a solução $200 \mu 1$ daquele meio com bactéria que cresceu durante a noite, mais $50 \mu 1$ de X-Gal a $2 \%$ (solução de X-Gal em dimetil-formaldeido), que é uma espécie de açúcar, além de $20 \mu 1$ de $100 \mu \mathrm{M}$ IPTG, que age como catalizador para a reação.

Misturamos tudo isto a $3 \mathrm{ml}$ de meio de cultura LTS, pré-mantido a $60^{\circ} \mathrm{C}$ e despejamos em uma placa de meio de cultura sólido, que já continha meio LB+Agar. Esperamos solidificar e colocamos a placa contendo as bactérias transformadas em sala a $36^{\circ} \mathrm{C}$, para as colônias crescerem durante a noite.

\subsubsection{Identificação e utilização das bactérias transformadas}

No dia seguinte, as placas devem conter colônias de bactérias transformadas e não. As colônias não transformadas possuem uma coloração azul, enquanto as transformadas são incolor. Cada colônia é formada a partir de uma única bactéria e, portanto, temos um clone da sequiência simples de DNA da amostra desejada individualizado, em grandes quantidades.

Retiramos cada colônia transformada e as colocamos em um tubo de ensaio

contendo $5 \mathrm{ml}$ de meio LB e, a seguir, adicionamos $200 \mu 1$ de uma nova solução de bactéria XL IB, não transformada, que havia crescido durante a noite, sob agitação a $36^{\circ} \mathrm{C}$.

Este tubo, que contem uma tampa que permite a entrada de ar para permitir que a solução fique sempre rica em oxigênio, evitando-se assim a morte da bactéria, era 
colocado em um ângulo de $45^{\circ}$ em um agitador com no mínimo 250rpm, durante 6 horas.

Após este período retirava-se $2,4 \mathrm{ml}$ de cada tubo de ensaio e colocava-se a metade disto em dois tubos de ependorf e eram centrifugados a $15.000 \mathrm{rpm}$ por 10 minutos. Retirava-se então $1 \mathrm{ml}$ de cada tubo e os colocava em um novo (evitando perturbar o precipitado) e, em seguida, adicionava-se 200 $\mu$ l de PEG (2g de PEG 6000; 5 $\mathrm{ml}$ de $5 \mathrm{M} \mathrm{NaCl}$; e água até completar $10 \mathrm{ml}$ ), e mantinha-se estes tubos em gelo por no mínimo 2 horas, podendo ser mantido durante a noite toda.

A solução neste ponto contém praticamente somente uma grande quantidade de vírus com a nossa amostra inserida nele, já que a bactéria ficou no precipitado anterior, o qual descartamos. O que fazíamos então era disponibilizar somente o material genético do vírus com nossa amostra, retirando a capa protéica, que é a carapaça que protege o material genético viral.

Em seguida centrifugamos os tubos a 15.000 rpm em câmara fria e descartamos o líquido. Com uma papel absorvente secamos qualquer gota restante, sem perturbar o precipitado. Adicionamos $100 \mu \mathrm{l}$ de TE, podendo, neste ponto, recombinar os dois tubos do mesmo clone, totalizando-se $200 \mu 1$ de solução.

Adicionava-se então, a este produto, $200 \mu 1$ de fenol fresco, centrifugando-se em temperatura ambiente (10 minutos, $15.000 \mathrm{rpm}$ ) e retirando a porção líquida superior para um novo tubo, desprezando o resto. Adicionava-se então $500 \mu 1$ de cloroformio: alcool-isoamil, centrifugando-o como anteriormente e, novamente, mantinha-se apenas a porção líquida superior, em um novo tubo.

Adicionava-se $20 \mu 1$ de $3 \mathrm{M}$ de acetado de sódio, PH 5,5 e completava-se com $100 \%$ etanol, incubando a $-20^{\circ} \mathrm{C}$ por pelo menos 1 hora. Centrifugava-se na câmara fria, descartando o líquido e adicionando $500 \mu \mathrm{l}$ de $70 \%$ etanol (pré-mantido a $-20^{\circ} \mathrm{C}$ ). Pequeno vortex e nova centrifugação, com descarte do líquido.

Secava-se então o tubo com o precipitado em câmara de vácuo e o ressuspendia em $21 \mu 1$ de água. Neste ponto a amostra estava pronta para ser sequenciada. 


\subsection{Sequenciamento}

Para o sequenciamento utilizamos o sequenciador automático ABI Prism 377/ $\mathrm{XL}$, com ion lazer de argônio. As amostras foram preparadas com o kit "Big Dye ${ }^{\mathrm{TM}}$ terminator cycle - ABI Prism”, que possui 4 dinucleotídeos-dye.

Para sequenciar as amostras, um novo PCR foi realizado para cada clone das amostras, utilizando os produtos do kit descrito acima e com apenas 1 primer, o qual reconhece uma porção do genoma do vírus M13 mp18, na proximidade do local onde a sequiência da nossa amostra estava inserida, amplificando-a mais uma vez.

Os parâmetros deste novo ciclo de PCR foram:

$96^{\circ} \mathrm{C}-30$ segundos;

$96^{\circ} \mathrm{C}-30$ segundos, $50^{\circ} \mathrm{C}-30$ segundos, $60^{\circ} \mathrm{C}-4$ minutos $(25$ ciclos $)$;

$72^{\circ} \mathrm{C}-30$ segundos.

Após este PCR, as soluções foram purificadas, antes de serem enviadas para serem sequenciadas, como descrevemos a seguir:

Adicionamos $30 \mu \mathrm{l}$ de isopropanol mais $10 \mu 1$ de água a cada tubo com o produto do PCR. Mantinha-se esta solução a temperatura ambiente por no mínimo 20 minutos. Centrifugava-se então por 20 minutos e, cuidadosamente, sem perturbar o precipitado, retirava-se a solução do tubo, utilizando-se para isto de uma micro-pipeta.

Adicionava-se então $250 \mu 1$ de $75 \%$ isopropanol e centrifugava-se por no mínimo 5 minutos, removendo-se, após isto, a solução, cuidadosamente. O resto da solução ainda restante no tubo era secado em máquina de $\mathrm{PCR}$, mantida a $93^{\circ} \mathrm{C}$ por 4 minutos. Ressuspendia-se o precipitado em $2 \mu l$ de blue-dye (componente do kit) e sequenciavase. 


\subsection{Análise das seqüências}

As sequiências obtidas foram alinhadas usando-se o programa CLUSTAL w (Thompson et al, 1994) e ajustadas a olho. Múltiplas sequiências foram obtidas de cada amostra para que fosse possível identificar e remover erros de polimerase ou determinar modificações de bases em potencial, no caso de DNA ancião. Sequiências foram comparadas usando-se a técnica de network (Allaby \& Brown, 2000).

\subsection{Procedimentos tomados para se evitar contaminação}

Com o objetivo de se evitar a contaminação das amostras arqueológicas com DNA de amostras modernas, diversas precauções foram tomadas, entre as principais citamos: utilização de salas diferentes para extração de DNA de amostras modernas e arqueológicas; uso de luvas de lotes diferentes; jalecos protetores distintos; micropipetas separadas para cada fase; soluções estoques distintas para cada tipo de material; tubos e material para preparo de soluções de lotes diferentes e mantido em salas diferentes; armazenagem de produtos de PCR em freezers diferentes, em salas diferentes e preparo de PCR em sala isolada; uso em qualquer etapa do processo de amostras controle, sem DNA, para traçar qualquer contaminação ao longo de cada fase, apenas citando as principais medidas adotadas para tentar evitar o risco de contaminação.

\subsection{Datação das amostras arqueológicas}

Para a datação do material foram utilizados fragmentos de coquinho $\underline{\text { Syagrus }}$ oleracea) e carvão encontrados nos silos, a fim de estimar indiretamente a idade de cada amostra de milho e feijão dos silos.

Os coquinhos e o carvão foram escolhidos para datação por serem mais abundantes e, como o método de datação é destrutivo, para não se perderem as amostras de milho e feijão. As idades obtidas com os coquinhos e o carvão podem ser 
extrapoladas para o milho e feijão, pois estes foram acondicionados juntos, na formação do silo escavado.

A datação do material foi realizada no CENA, Centro de Energia Nuclear na Agricultura, USP, em Piracicaba, SP, utilizando a metodologia de datação radiocarbônica por espectrometria de cintilação líquida com benzeno (Pessenda \& Camargo, 1991).

A única exceção foi em relação a amostra P3 de feijão, a qual foi datada no laboratório de arqueologia em Oxford, Inglaterra, utilizando-se um acelerador de carbono. Neste caso, o material utilizado para a datação foi a vagem do próprio grão estudado. 


\section{RESULTADOS E DISCUSSÃO}

\subsection{Idade das amostras}

As idades das amostras que trabalhamos estão mostradas nas próximas três tabelas. Note que a primeira se refere às amostras arqueológicas de milho que trabalhamos diretamente (tabela 7), a segunda se refere às amostras de milho arqueológico utilizadas no trabalho de Goloubinoff et al (1993) (tabela 8) e que usamos como comparação e, a terceira tabela (tabela 9), se refere às idades das amostras de feijão arqueológicos que também trabalhamos diretamente.

\begin{tabular}{|c|c|c|c|c|c|}
\hline SIGLA & FONTE & LOCALIZAÇÃO & IDADE* & & \\
\hline A2 & Boquete & Januaria-MG & $570 \pm 60$ & & \\
\hline A3 & Boquete & Januaria-MG & $890 \pm 50$ & & \\
\hline A5 & Lapa Hora & Januaria-MG & $630 \pm 60$ & $\mathrm{e}$ & dade de cada amostra de \\
\hline A6 & Lapa Hora & Januaria-MG & $630 \pm 60$ & $\mathrm{mi}$ & tho arqueológico. Note \\
\hline A8 & Boquete & Januaria-MG & $570 \pm 60$ & $\begin{array}{l}\text { qut } \\
\text { po }\end{array}$ & $\begin{array}{l}\text { a amostra A34 ainda não } \\
\text { ssui idade determinada. }\end{array}$ \\
\hline A23 & Boquete & Januaria-MG & $940 \pm 60$ & & \\
\hline A34 & Caboclo & Januaria-MG & - & & \\
\hline
\end{tabular}

* AP - Antes do Presente, tendo o ano de 1950

de nossa era como data inicial de referência.

\begin{tabular}{|llll|}
\hline SIGLA & LOCAL & PAÍS & IDADE \\
\hline G6 & Hastorf & Montanhas - Peru & $440 \pm 40$ \\
\hline G7 & Tenney & Norte do Chile & $1500 \pm 50$ \\
\hline G8 & Bonavia & Costa do Peru & $4500 \pm 500$ \\
\hline
\end{tabular}

Tabela 8. Sigla, local e idade de cada amostra de milho arqueológico. Dados obtidos em Goloubinoff et al (1993). 


\begin{tabular}{|llll|}
\hline SIGLA & LOCAL & PAÍS & IDADE \\
\hline P1 & Boquete & Januaria - MG & $3430 \pm 70$ \\
\hline P2 & Boquete & Januaria - MG & $1350 \pm 60$ \\
\hline P3 & Boquete & Januaria - MG & $251 \pm 39$ \\
\hline
\end{tabular}

Tabela 9. Sigla, local e idade de cada amostra de feijão arqueológico.

\subsection{Amplificação, clonagem e seqüências obtidas}

\subsubsection{Amplificação}

Ao mesmo tempo em que o PCR é um método muito eficiente e sensível, quando se trata de amplificar fragmentos de DNA, pode-se dizer que pequenos detalhes podem impedir que esta amplificação ocorra. Impurezas, diferenças de concentração de soluções e, principalmente, DNA comprometido, podem fazer com que não obtenhamos DNA para análise de uma dada percentagem das amostras pretendidas.

Quando se trata de amostras arqueológicas esta dificuldade aumenta ainda mais, pois aí o fator tempo, ligado às ações do intemperismo (físico, químico e biológico/microorganismos) é um grande adversário contra a preservação do material genético das amostras. Deste modo, parte das amostras que iniciamos o trabalho e que pretendíamos analisar, não obtivemos sucesso em amplificar DNA para análise.

No caso do milho, das 20 amostras arqueológicas trabalhadas (dados não apresentados), obtivemos DNA amplificado de 7 delas (Tabela 7). Já para o feijão arqueológico, das três amostras, apenas com uma conseguimos dar prosseguimento nas análises (amostra P3).

Em relação as duas amostras arqueológicas de feijão infrutíferas, além delas serem de uma idade bem antiga, elas eram fragmentos da vagem desta leguminosa, região esta que além de possuir uma concentração de DNA menor do que a existente no 
grão, naturalmente também não possui mecanismos de preservação de seu material genético tão eficientes quanto o encontrado nas sementes e grãos das espécies em geral ${ }^{1}$.

Chamamos a atenção ainda para as amostras F14 e F15, de feijão, onde obtivemos DNA amplificado destas para o alvo do PCR2, enquanto as varias tentativas de se conseguir amplificação destas para o alvo PCR1 também foram infrutíferas. Como o material utilizando para ambos os alvos do PCR partiram de uma mesma solução de DNA extraído e isolado, podemos dizer que existia DNA na solução para amplificação, mas algo impediu que este fosse amplificado para o alvo PCR1.

Uma provável explicação para este fato pode ser que na região do sítio de ligação dos primers do PCR1 destas duas amostras, em particular, a sequiência de DNA pode apresentar mutações nas bases nitrogenadas, o que não permite o reconhecimento, acoplamento e, por conseqüência, a amplificação destas duas amostras. Como estas duas amostras foram coletadas em regiões geograficamente próximas e, portanto, podendo haver recombinação, troca de alelos, existe a possibilidade de que caso uma das amostras sofresse uma mutação neste sítio de ligação do primer, esta poderia ser transmitida para a outra, por recombinação genética. Esta hipótese pode ser averiguada se construirmos novos primers que flanqueiem a região originalmente compreendida por este alvo, amplificando uma região maior desta parte do gene e, assim, ao sequenciarmos esta nova região, poderíamos observar se estas regiões-alvos possuem seqüências diferentes das demais, ou não.

\subsubsection{Clonagem e Sequenciamento}

A partir do material amplificado no PCR, fizemos diversos clones de cada amostra e sequenciamos (tabelas 10 e 11), com o intuito de diferenciarmos possíveis erros na sequiência de nucleotídios ocorridos durante o processo de polimerização, no PCR, daquelas potenciais mutações, reais, acumuladas pelo tempo, que são o registro evolutivo ocorrido na espécie e que usamos nas análises.

\footnotetext{
${ }^{1}$ Allabi, R (UMIST-Manchester) Comunicação pessoal, 1999.
} 
Utilizamos para análise apenas aquelas mutações que apareceram em uma dado sítio do fragmento em mais de uma seqüência/ clone, eliminando aquelas mutações exclusivas observadas em apenas uma delas, já que estas últimas possuem grande chance de serem erros durante o processo de polimerização.

Com isto, após eliminados os erros causados pela polimerase, nós tínhamos várias sequiência advindas das amostras (figura 4 -milho; figura 5 - feijão PCR1 e figura 6- Feijão- PCR2), as quais podemos chamar de alelos, e que foram comparadas.

Tabela 10. Amostras de milho arqueológicas e modernas analisadas e seus respectivos números de clones obtidos e de alelos diferentes encontrados em cada amostra.

\begin{tabular}{|c|c|c|c|c|c|c|c|c|c|c|c|c|c|c|c|c|c|c|}
\hline $\begin{array}{c}\text { SIGL } \\
A\end{array}$ & E1 & $\mathrm{E5}$ & E6 & $\mathrm{E9}$ & E11 & $\begin{array}{l}\mathrm{E} 1 \\
2\end{array}$ & E13 & $\overline{\mathrm{E} 14}$ & $\overline{E 15}$ & $\overline{E 21}$ & $\overline{\mathrm{E} 23}$ & $\overline{\mathrm{A} 2}$ & $\overline{\mathbf{A 3}}$ & $\overline{\mathrm{A5}}$ & $A 6$ & A8 & $\overline{\mathrm{A} 23}$ & $\overline{\mathrm{A34}}$ \\
\hline $\begin{array}{l}\mathrm{N}^{\circ} \mathrm{de} \\
\text { clones }\end{array}$ & 2 & 2 & 3 & 2 & 5 & 2 & 4 & 6 & 6 & 5 & 5 & 5 & 5 & 6 & 5 & 4 & 6 & 5 \\
\hline $\begin{array}{l}\mathrm{N}^{\circ} \text { de } \\
\text { alelos }\end{array}$ & 1 & 1 & 1 & 2 & 1 & 1 & 2 & 2 & 2 & 2 & 2 & 2 & 2 & 2 & 1 & 2 & 1 & 1 \\
\hline
\end{tabular}

Tabela 11. Amostras de feijão utilizadas, localização, tipo de Phaseolina de cada amostra, número de clones obtidos e respectivos números de alelos diferentes encontrados em cada amostra, para as duas regiões alvos do PCR.

\begin{tabular}{|c|c|c|c|c|c|c|}
\hline \multirow[t]{2}{*}{ Sigla } & \multirow[t]{2}{*}{ Localização } & \multirow{2}{*}{$\begin{array}{l}\text { Tipo de } \\
\text { phaseolina }\end{array}$} & \multicolumn{2}{|c|}{$\mathbf{N}^{\oplus}$ de clones obtidos } & \multicolumn{2}{|c|}{$\mathbf{N}^{\circ}$ de alelos difrentes } \\
\hline & & & PCR1 & PCR2 & PCR1 & PCR2 \\
\hline F8 & Salta - Argentina & $\mathrm{T}$ & 5 & 3 & 4 & 3 \\
\hline F9 & Tucuman - Argentina & $\mathrm{J}$ & 5 & 4 & 4 & 2 \\
\hline F10 & Cundinamarca - Colômbia & $\mathrm{B}$ & 5 & 5 & 5 & 5 \\
\hline F11 & Apurimac - Peru & $\mathrm{H}$ & 5 & 4 & 4 & 4 \\
\hline F12 & Cundinamarca - Colômbia & $\mathrm{CH}$ & 2 & 6 & 1 & 5 \\
\hline F13 & Piura - Peru & I & 3 & 3 & 2 & 2 \\
\hline F14 & Cuzcu - Peru & $\mathrm{P}$ & -- & 5 & -- & 2 \\
\hline F15 & Cuzcu - Peru & $\mathrm{C}$ & -- & 6 & -- & 6 \\
\hline F16 & Durango - México & $\mathrm{M}$ & 4 & 5 & 3 & 5 \\
\hline F17 & Jalisco-México & $\mathrm{S}$ & 5 & 5 & 4 & 5 \\
\hline P3 & Januaria, MG - Brasil - Arq. & & 3 & 8 & 2 & 7 \\
\hline
\end{tabular}


Observando as duas tabelas anteriores e se lembrarmos que para cada amostra foi utilizado apenas um indivíduo (seja um grão, um sabugo ou uma palha), vemos que, no caso das amostras de milho, o número de alelos diferentes encontrados para cada amostra somente varia entre 1 e 2 , o que é de se esperar para um genoma diploide, enquanto, no caso das de feijão, encontramos até 7 alelos diferentes para um mesmo genoma/ indivíduo.

Este fato é explicado porque enquanto o gene $\mathrm{ADH} 2$, no milho, é um gene simples, que possui apenas uma cópia ao longo de todo seu genoma e, portanto, o número máximo de alelos possíveis é igual a dois (um para cada cromossomo homólogo). No caso do feijão, o gene da Phaseolina é, na verdade, um complexo de 6 a 10 genes, que podem ser chamados de família de multigene, ainda não totalmente decifrados (Kami et al, 1995) e, deste modo, o número de alelos diferentes possíveis de serem encontrados dentro de um mesmo genoma para o gene Phaseolin pode chegar até 12 ou mesmo 20 alelos.

Nas páginas seguintes estão apresentados os alinhamentos das sequencias/alelos de milho e feijão (PCR 1 e 2), nas figuras 4, 5 e 6, respectivamente. Note que nos alinhamentos utilizamos seqüências disponíveis em trabalhos de literatura (Goloubinoff et al,1993) e no banco mundial de genes, para que, deste modo, tivéssemos condições de ampliar o poder de comparação e análise, sendo ainda que, para o feijão, duas delas são da espécie Ph. lunatus, o qual foi usado como um "out group", o que permite que tenhamos uma idéia do nível de distância evolutiva entre esta última espécie e o $P h$. vulgaris.

Para uma melhor visualização dos dados e interpretação, as amostras de milho e as amostras de feijão da região do PCR2 foram plotadas em um gráfico de Network (figuras 7 e 10, respectivamente), o qual além de nos permitir visualizar a relação filogenética existente entre as diversas amostras/ alelos obtidos, também nos permite que tenhamos uma idéia mais clara de quais foram as transformações ocorridas durante o processo evolutivo de cada uma das espécies.

As amostras do PCR1 de feijão não foram plotadas em um gráfico de network e o motivo principal é que não dispúnhamos dos dados das amostras F14 e F15, como 
explicado anteriormente, fazendo com que a análise comparativa por este método ficasse debilitada. Deste modo, optamos por analisar apenas a região PCR 2 por esta metodologia.

No gráfico de network as amostras são agrupadas dependendo de sua similaridade genética. Nele, os números mostrados entre as amostras representa a posição da base nitrogenada que diverge entre duas ou mais sequências de amostras, ou seja, representam as mutações que ocorreram no passado e que foram acumuladas nos diferentes alelos das amostras.

Suas análises, interpretações e conclusões se farão em separado, para cada uma das espécies e estão apresentadas nos itens descriminados, mais à frente. 
Figura 4. Alinhamento das sequiências do fragmento do gene Adh2, em milho, com todas as amostras utilizadas e seus respectivos alelos. Note que todas as amostras iniciadas com a sigla "G" foram obtidas do trabalho de Goloubinoff et al (1993) e a amostra "Dennis" foi obtida diretamente do banco mundial de sequiências genéticas.

E1-A
E5-A
E6-A
E9-A
E9-B
E11-A
E12-A
E13-A
E13-B
E14-A
E14-B
E15-A
E15-B
E21-A
E21-B
E23-A
A2-A
A2-B
A3-A
A3-B
A5-A
A5-B
A6-A
A8-A
A8-B
A23-A
A34
G-1A
G-1B
G-BF
G-3
G-4
G-5
G-6
G-7A
G-7B
G-7C
G-8A
G-8B
G-9A
G-9B
G-10A
G-10B
G-11A
G-11B
G12-A
G-12B
DENNIS

TCTCGTGtTC TTGGAgtgGt CCATCGAtCG AgCtCCGTGA GAGA-

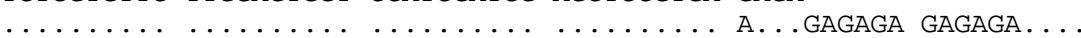

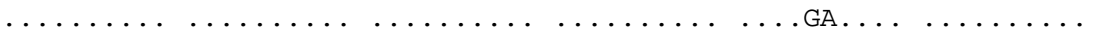

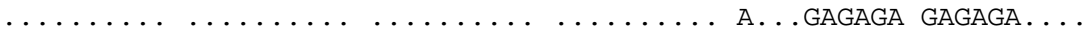

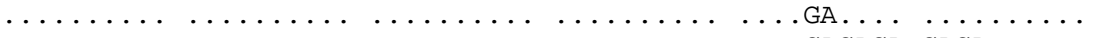

$\ldots \ldots \ldots \ldots \ldots \ldots \ldots \ldots \ldots \ldots \ldots \ldots \ldots \ldots$ GAGA GAGA $\ldots \ldots \ldots$

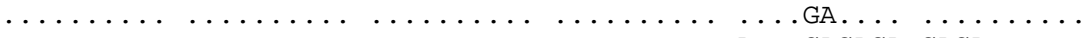

$\ldots \ldots \ldots \ldots \ldots \ldots \ldots \ldots \ldots \ldots \ldots \ldots \ldots \ldots$. $\ldots \ldots \ldots$ GAGA GAGA $\ldots \ldots$

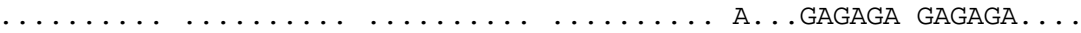

$\ldots \ldots \ldots \ldots \ldots \ldots \ldots \ldots$. $\ldots \ldots \ldots \ldots$ GAGAGA GAGAGA...

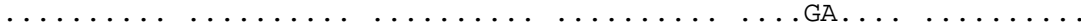

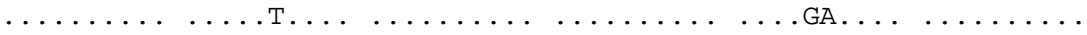

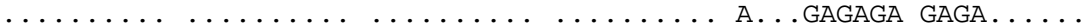

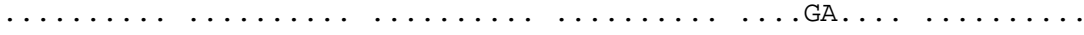

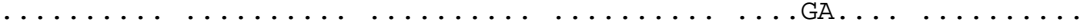

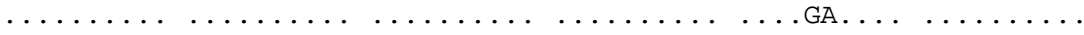

$\ldots \ldots \ldots \ldots \ldots \ldots \ldots . \ldots \ldots$. $\ldots \ldots \ldots$ GAGAGA GAGAGA....

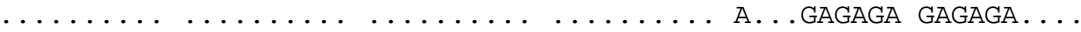

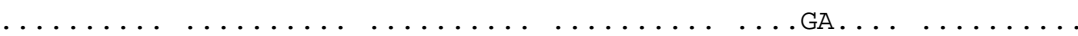

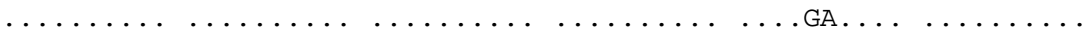

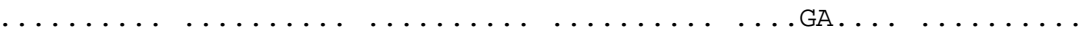

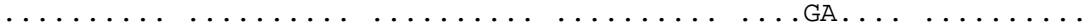

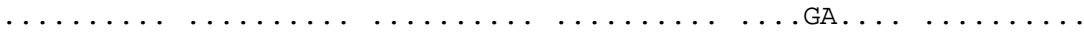

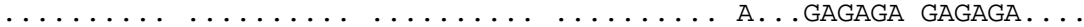

$\ldots \ldots \ldots \ldots \ldots \ldots \ldots \ldots$. $\ldots \ldots \ldots$ GAGAGA GAGAGA....

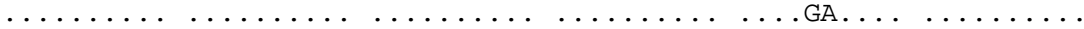

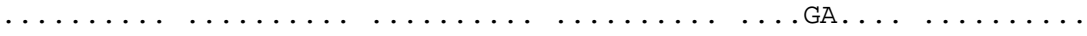

$\ldots \ldots \ldots \ldots \ldots \ldots \ldots$. $\ldots \ldots$ GAGAG GAGAGAGAGA

$\ldots \ldots \ldots \ldots \ldots \ldots \ldots \ldots \ldots \ldots \ldots . \ldots \ldots$

$\ldots \ldots \ldots \ldots \ldots$ A. . $\ldots \ldots$ GAGA GAGA $\ldots \ldots$

$\ldots \ldots \ldots \ldots \ldots \ldots \ldots \ldots \ldots \ldots$

$\ldots \ldots \ldots \ldots \ldots \ldots \ldots \ldots \ldots \ldots$

$\ldots \ldots \ldots \ldots \ldots \ldots$. $\ldots \ldots$ GAGAGA GAGA $\ldots \ldots$

$\ldots \ldots \ldots \ldots \ldots . \ldots . . . .$.

$\ldots \ldots \ldots \ldots \ldots \ldots \ldots \ldots \ldots$

$\ldots \ldots \ldots \ldots \ldots \ldots \ldots \ldots$

$\ldots \ldots \ldots \ldots \ldots \ldots \ldots$

$\ldots \ldots \ldots \ldots$.................

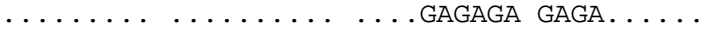

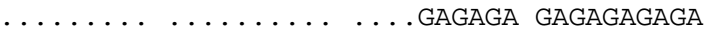

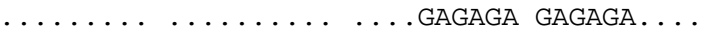

$\ldots \ldots \ldots \ldots \ldots \ldots \ldots \ldots \ldots$

$\ldots \ldots \ldots \ldots \ldots \ldots \ldots$ GAGAGA $\ldots \ldots \ldots \ldots$

$\ldots \ldots \ldots \ldots \ldots \ldots$. $\ldots \ldots$ GAGAGA GA. ......

$\ldots \ldots \ldots \ldots \ldots \ldots$. $\ldots \ldots$ GAGAGA GAGAGA...

$\ldots \ldots \ldots \ldots \ldots \ldots \ldots$. . . . . . . . . . .

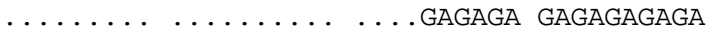

.....-- -. . . . ... ... GAGAGA AACA.....

$\ldots \ldots \ldots \ldots . . . \ldots$ A... GAGAGA GAGAGA.... 
|exon

|intron

120

E1-A ----TAGCAAGCA ATG GCG ACA GCA GGg AAg GTG ATC AAG TGC AGA G GTGCGTGCGTCTT . $\ldots \ldots \ldots \ldots \ldots \ldots \ldots \ldots \ldots \ldots$

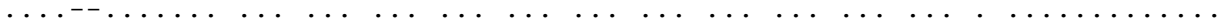
$\begin{array}{lllllllllllllllllll} & \ldots & \ldots & \ldots & \ldots & \ldots & \ldots & \ldots & \ldots & \ldots & \ldots & \ldots & \ldots & \ldots & \ldots & \ldots & \ldots & \ldots\end{array}$

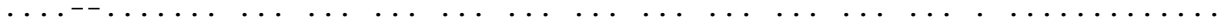

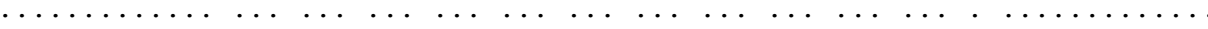

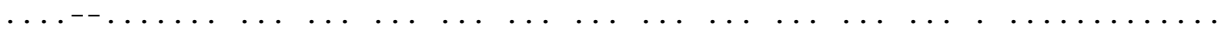

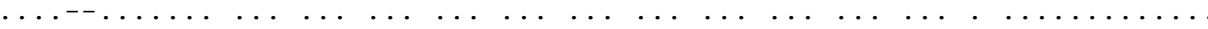

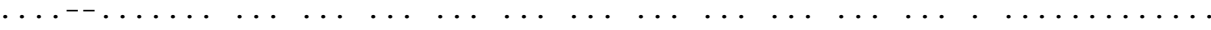

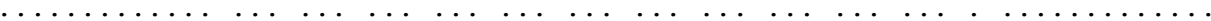
$\begin{array}{lllllllllllllllll} & \ldots & \ldots & \ldots & \ldots & \ldots & \ldots & \ldots & \ldots & \ldots & \ldots & \ldots & \ldots & \ldots & \ldots & \ldots & \ldots\end{array} \ldots \ldots$

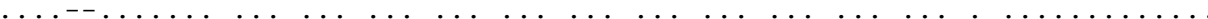

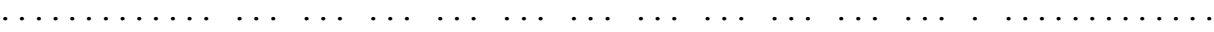

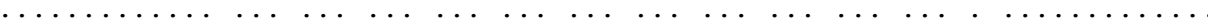

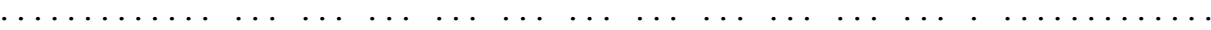

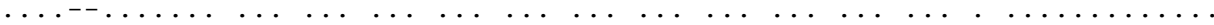
$\begin{array}{lllllllllllllll}\ldots-- & \ldots & \ldots & \ldots & \ldots & \ldots & \ldots & \ldots & \ldots & \ldots & \ldots & \ldots & \ldots & \ldots & \ldots\end{array} \ldots \ldots \ldots$

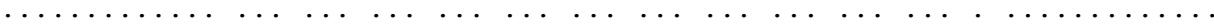

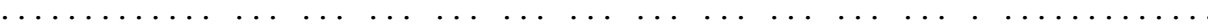

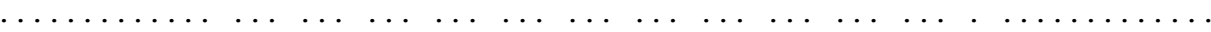

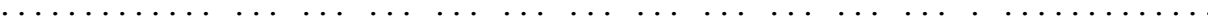

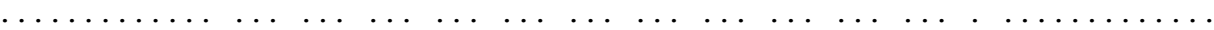

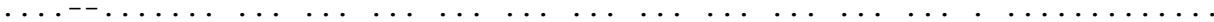

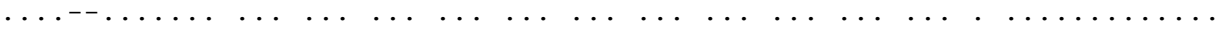

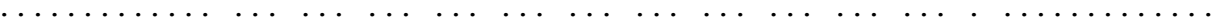

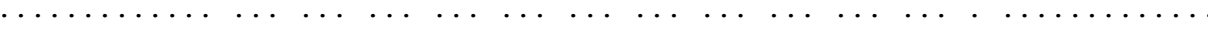

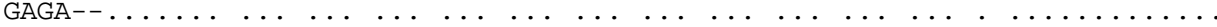

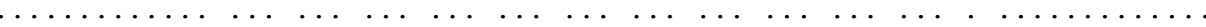
$\begin{array}{lllllllllllllll}\ldots- & \ldots & \ldots & \ldots & \ldots & \ldots & \ldots & \ldots & \ldots & \ldots & \ldots & \ldots & \ldots & \ldots & \ldots\end{array} \ldots \ldots \ldots$

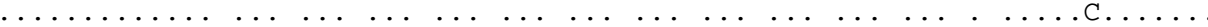

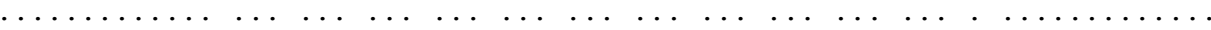

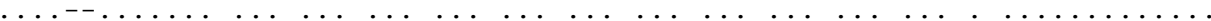

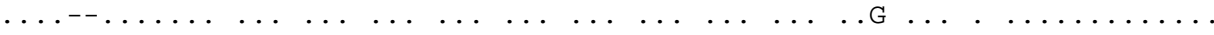

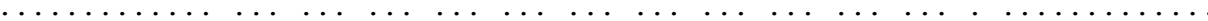

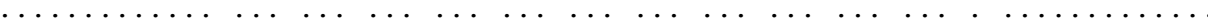

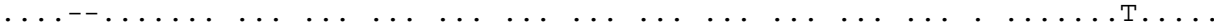
$\begin{array}{lllllllllllllll}\ldots-- & \ldots & \ldots & \ldots & \ldots & \ldots & \ldots & \ldots & \ldots & \ldots & \ldots & \ldots & \ldots & \ldots & \ldots\end{array} \ldots \ldots \ldots$

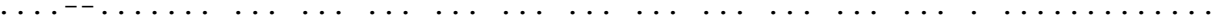
$\begin{array}{llllllllllllll}\operatorname{GAGAG} \ldots \ldots \ldots & \ldots & \ldots & \ldots & \ldots & \ldots & \ldots & \ldots & \ldots & \ldots & \ldots & \ldots & \ldots & \ldots\end{array} \ldots \ldots$ $\begin{array}{lllllllllllllll}\ldots \ldots & \ldots & \ldots & \ldots & \ldots & \ldots & \ldots & \ldots & \ldots & \ldots & \ldots & \ldots & \ldots & \ldots & \cdots\end{array} \ldots$

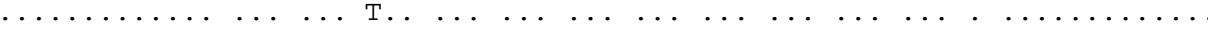

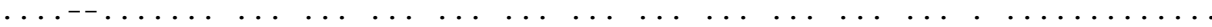

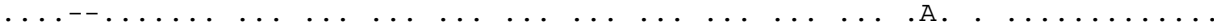

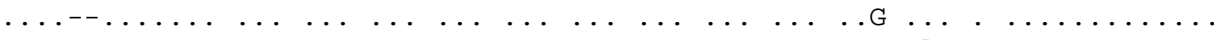

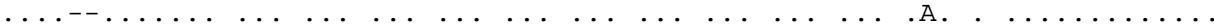
$\begin{array}{lllllllllllllll}\operatorname{GAGAG} \ldots \ldots \ldots & \ldots & \ldots & \ldots & \ldots & \ldots & \ldots & \ldots & \ldots & \ldots & \ldots & \ldots & \ldots & \ldots & \ldots\end{array}$

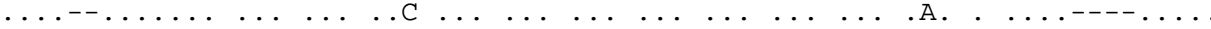

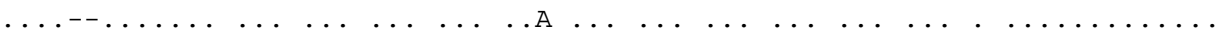


CTACC-TC-- CGCCTTTCGT GATGGCTACT GGTT----AG C-AGCCTAGC T-AATC-ATT

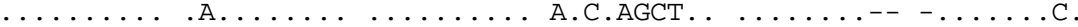

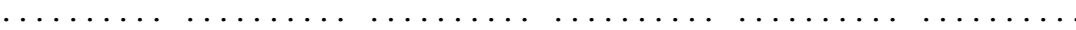

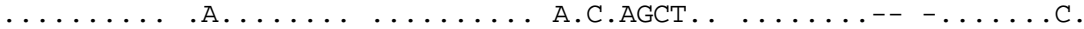

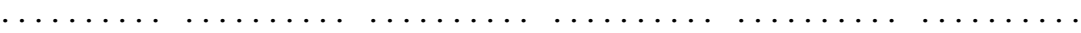

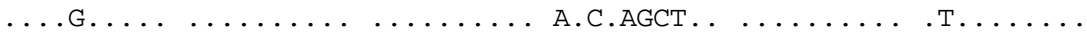

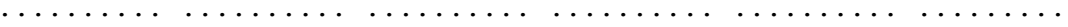

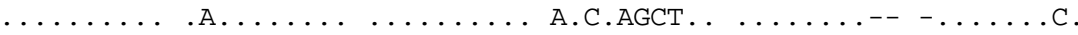
$\ldots \ldots \ldots \ldots$. ...........А.С.АGСТ . .....- -.... . $\ldots \ldots \ldots$. ...........А.С.АGСТ......-- ......

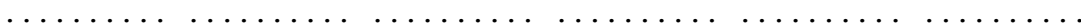

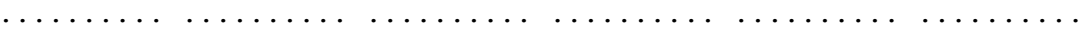
$\ldots \ldots \ldots \ldots$. .......... А.С.АGCT.. ....-- ....С.

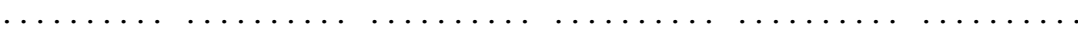

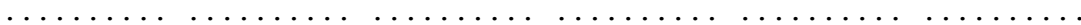

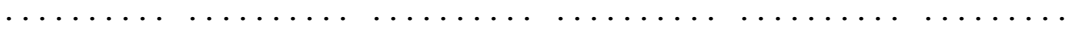

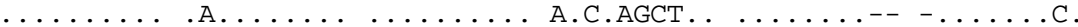
$\ldots \ldots \ldots \ldots$. ........... А. С АССТ . .....- .....

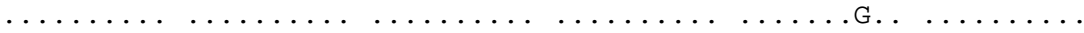

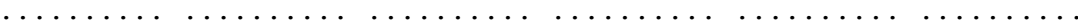

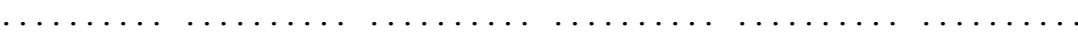

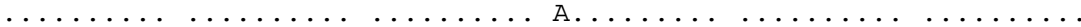

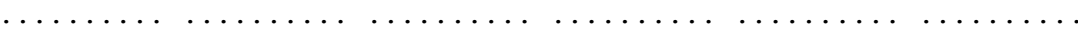

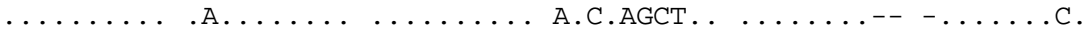
$\ldots \ldots \ldots$. ........... А. С.АGСТ . .....- ... . С.

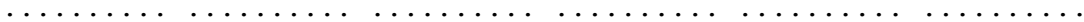

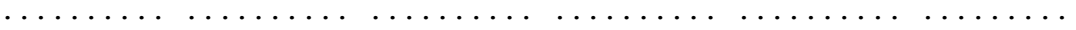

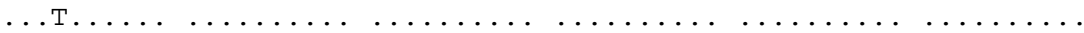

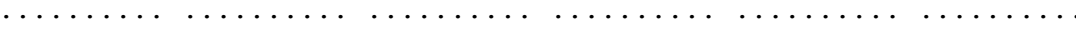

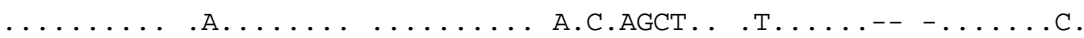

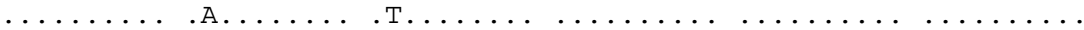

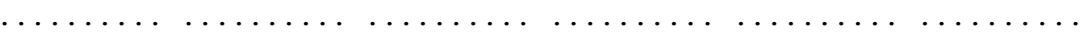

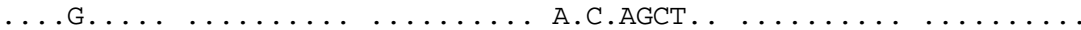

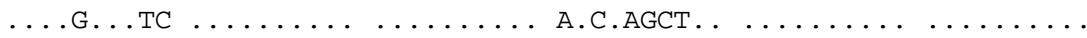
$\ldots \ldots \ldots \ldots$. ......... А.С.АGСТ . .....- $\ldots \ldots \ldots$.

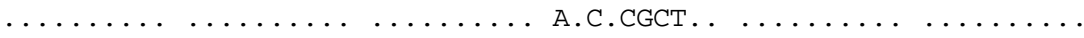

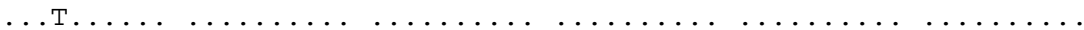

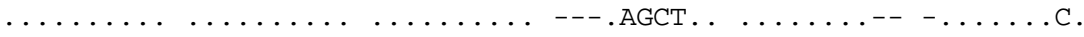

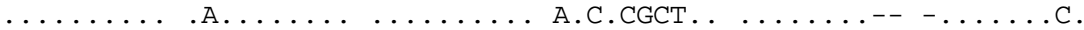

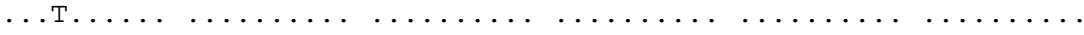

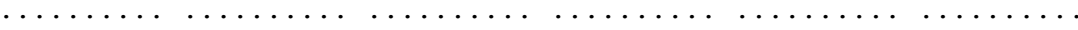
$\ldots \ldots \ldots \ldots$. ...........А.С.СGCT.......- .....

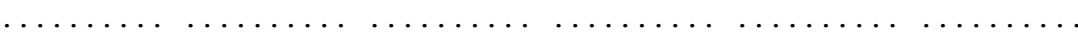

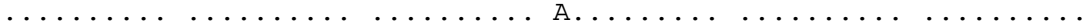
$\ldots \ldots, \ldots \ldots \ldots \ldots \ldots \ldots \ldots \ldots \ldots \ldots \ldots \ldots \ldots \ldots \ldots \ldots$

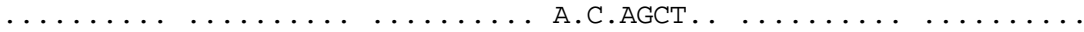

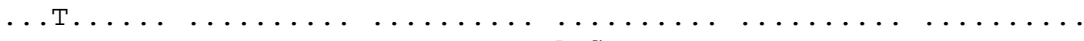
$\ldots \ldots \ldots \ldots \ldots \ldots \ldots \ldots \ldots \ldots$ А. . ............. . . . . . . . $\ldots \ldots \ldots \ldots$ А...........А.С.АGСТ . .....-- ....С. 
200

E1-A GTATtGAtT TGTTCTTGGA TCC

$\mathrm{E} 5-\mathrm{A}$

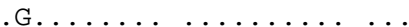

$\ldots \ldots \ldots \ldots \ldots \ldots$

.$G \ldots \ldots \ldots \ldots \ldots \ldots \ldots$

$\ldots \ldots \ldots \ldots \ldots \ldots \ldots$

.$G \ldots \ldots \ldots \ldots \ldots \ldots \ldots$

$\cdots \ldots \ldots \ldots \ldots \ldots$

.G.............

.$G \ldots \ldots \ldots \ldots \ldots \ldots \ldots$

.G.............

$\ldots \ldots \ldots \ldots \ldots \ldots$

$\ldots \ldots \ldots \ldots \ldots$ G.

.$G \ldots \ldots \ldots \ldots \ldots \ldots \ldots \ldots$

$\ldots \ldots \ldots \ldots \ldots \ldots$

$\ldots \ldots \ldots \ldots \ldots \ldots \ldots$

$\ldots \ldots \ldots \ldots \ldots \ldots$

.$G \ldots \ldots \ldots \ldots \ldots \ldots$

. $\mathrm{G} \ldots \ldots \ldots \ldots \ldots \ldots$

$\ldots \ldots \ldots \ldots \ldots \ldots \ldots$

$\begin{array}{lll}\cdots \cdots \cdots & \cdots \cdots\end{array}$

$\ldots \ldots \ldots \ldots \ldots$

$\ldots \ldots \ldots \ldots \ldots \ldots \ldots$

$\ldots \ldots \ldots \ldots \ldots$

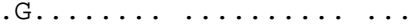

.$G \ldots \ldots$ C. ...........

$\ldots \ldots \ldots \ldots \ldots \ldots \ldots$

$\ldots \ldots \ldots \ldots \ldots \ldots$

$\ldots \ldots \ldots \ldots \ldots \ldots$

$\cdots \ldots \ldots \ldots \ldots \ldots$

.$G \ldots \ldots \ldots \ldots \ldots \ldots$

$\ldots \ldots \ldots \ldots \ldots \ldots \ldots$

$\ldots \ldots \ldots \ldots \ldots \ldots$

.$G \ldots \ldots \ldots \ldots \ldots \ldots \ldots$

.$G \ldots \ldots \ldots \ldots \ldots \ldots$

.$G \ldots \ldots \ldots \ldots \ldots \ldots$

$\ldots \ldots \ldots \ldots \ldots \ldots$

.$G \ldots \ldots \ldots \ldots \ldots \ldots$

.$G \ldots \ldots \ldots$. . C . . . .

.$G \ldots \ldots \ldots \ldots \ldots \ldots$

$\ldots \ldots \ldots \ldots \ldots \ldots \ldots$

$\ldots \ldots \ldots \ldots \ldots$

.$G \ldots \ldots \ldots \ldots \ldots \ldots \ldots$

$\cdots \ldots \ldots \ldots \ldots \ldots$

.G...............

.$G \ldots \ldots \ldots \ldots \ldots \ldots$

.$G \ldots \ldots \ldots \ldots \ldots \ldots \ldots$

$\ldots \ldots \ldots \ldots \ldots$

.G.C..............

.$G \ldots \ldots \ldots \ldots \ldots$ 
Figura 5. Alinhamento das seqüências do fragmento do gene Phaseolina - PCR 1 em feijão, com seus respectivos alelos. Nota-se que as 9 (nove) últimas sequiências alinhadas foram obtidas diretamente do banco mundial de seqüências genéticas, sendo que destas, as duas últimas são da espécie Ph. lunatus, usadas neste trabalho como um "out group".

\begin{tabular}{|c|c|c|c|c|c|c|}
\hline $\mathrm{pn}$ & GTGTTGGG & GCTTACGTTC & TC-TGGGTCT & GGTGA-CGAA & GTTATGAAGC & $\mathrm{T}-\mathrm{GATC}$ \\
\hline & $\cdots \cdots \cdots$ & $\cdots \cdots \cdots \cdots$ & $\ldots \ldots \ldots$ & $\cdots \cdots \cdots$ & $\cdots \cdots \cdots \cdots$ & $\cdots \cdots \cdots$ \\
\hline & $\ldots \ldots$ & $\ldots \ldots \ldots$ & $\ldots \ldots \ldots$ & $\ldots \ldots \ldots$ & $\ldots \ldots \ldots$ & ...G.T. \\
\hline & $\cdots \cdots \cdots$ & $\cdots \cdots \cdots$ & $\ldots \ldots \ldots$ & $\ldots \ldots A-\ldots$ & $\ldots \ldots \ldots$ & $\ldots \ldots$ \\
\hline & $\ldots \ldots \ldots$ & $-\ldots \ldots \ldots$ & . c...... & $\ldots$.... & $\ldots \ldots \ldots$ & $\ldots \ldots$ \\
\hline & $\cdots \cdots \cdots$ & $\cdots \cdots \cdots$ & $\ldots \ldots \ldots$ & $\cdots \cdots$ & $\ldots \ldots \ldots$ & $\ldots \ldots$ \\
\hline & $\ldots \ldots \ldots$ & $\ldots \ldots \ldots$ & $\ldots \ldots \ldots$ & $\ldots \ldots \ldots$ & $\ldots \ldots \ldots$ & $\ldots \ldots$ \\
\hline & $\ldots \ldots \ldots$ & $\ldots \ldots \ldots$ & $\ldots \ldots \ldots \ldots$ & $\ldots \ldots A-\ldots$ & $\ldots \ldots \ldots$ & T..... \\
\hline & $\ldots \ldots \ldots$ & $\ldots \ldots \ldots$ & $\ldots \ldots \ldots$ & $\ldots \ldots \ldots$ & $\ldots \ldots \ldots$ & $\ldots \ldots G \ldots$ \\
\hline$-B$ & $\ldots \ldots \ldots$ & $\cdots \cdots$ & $\ldots \ldots \ldots$ & $\ldots \ldots \ldots$ & $\ldots \ldots \ldots$ & $\ldots \ldots G \ldots$ \\
\hline & $\ldots \ldots \ldots$ & $\ldots \ldots \ldots$ & $\ldots \ldots \ldots$ & $\ldots \ldots A-\ldots$ & $\ldots \ldots \ldots$ & $\ldots \ldots$ \\
\hline$-D$ & $\ldots \ldots \ldots$ & & $\ldots \ldots \ldots$ & $\ldots \ldots A-\ldots$ & $\ldots \ldots$ & ..G.... \\
\hline & $\ldots \ldots \ldots$ & $\ldots \ldots \ldots$ & $\ldots \ldots \ldots$ & $\ldots \ldots A-\ldots$ & $\ldots \ldots \ldots$ & $\ldots \ldots c$ \\
\hline$-B$ & $\ldots \ldots \ldots$ & $\ldots \ldots \ldots$ & $\ldots \ldots \ldots$ & $\ldots \ldots A-\ldots$ & & $\ldots \ldots \ldots$ \\
\hline & $\ldots \ldots \ldots$ & $\ldots \ldots \ldots$ & $\ldots \ldots \ldots$ & $\ldots C \ldots \ldots$ & $\ldots \ldots \ldots$ & $\ldots \mathrm{G} . \mathrm{T}$ \\
\hline$-D$ & $\ldots \ldots \ldots$ & & $\ldots \ldots \ldots$ & $\ldots \ldots \ldots$ & & 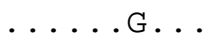 \\
\hline & $\ldots \ldots \ldots$ & $\ldots \ldots \ldots$ & $\ldots \ldots \ldots$ & $\ldots \ldots A-\ldots$ & & $\ldots \ldots \ldots$ \\
\hline$-\mathrm{A}$ & & & & & & ....G. . \\
\hline$-B$ & $\ldots \ldots \ldots$ & $\ldots \ldots \ldots$ & $\ldots \ldots \ldots \ldots$ & $\ldots \ldots \ldots$ & $\ldots \ldots \ldots$ & $\ldots$. G. \\
\hline & $. \ldots . \mathrm{T}$ & $\mathrm{T} \ldots \ldots-\ldots$ & $\ldots \ldots \ldots \ldots$ & $\ldots \ldots \mathrm{T} \ldots$ & $\ldots \ldots \ldots$ & $\ldots$..... \\
\hline$-\mathrm{A}$ & $\ldots \ldots \ldots$ & $\ldots \ldots \ldots$ & $\ldots \ldots \ldots \ldots$ & $\ldots \ldots \ldots$ & $\ldots \ldots \ldots$ & $\ldots \ldots G \ldots$ \\
\hline & $\ldots \ldots \ldots$ & $\ldots \ldots \ldots \ldots$ & $\ldots \ldots \ldots \ldots$ & $\ldots \ldots \ldots$ & $\ldots \ldots \ldots$ & $\ldots$. . G. \\
\hline$-\mathrm{C}$ & $\ldots \ldots \ldots$ & $\ldots \ldots \ldots$ & $\ldots \ldots \ldots \ldots$ & $\ldots \ldots A-\ldots$ & $\ldots \ldots \ldots$ & $\ldots \ldots \ldots$ \\
\hline & $\ldots \ldots \ldots$ & $\ldots \ldots \ldots$ & $\ldots \ldots \ldots \ldots$ & $\ldots \ldots \ldots$ & $\ldots \ldots \ldots$ & $\ldots \ldots G \ldots$ \\
\hline$-B$ & $\ldots \ldots \ldots$ & $\ldots \ldots \ldots$ & $\ldots \ldots \ldots$ & $\ldots \ldots \ldots$ & $\ldots \ldots$ & $\ldots$. G . . \\
\hline & $\ldots \ldots \ldots$ & $\ldots \ldots$ & $\ldots \ldots \ldots$ & $\cdots$ & $\ldots \ldots$ & $\ldots \ldots G \ldots$ \\
\hline$-D$ & $\ldots \ldots \ldots$ & $\ldots \ldots \ldots$ & $\ldots \ldots \ldots$ & $\ldots \ldots A-\ldots$ & $\ldots \ldots$ & $\ldots \ldots \ldots$ \\
\hline & . . & $\cdots$ & $\ldots$ & $\ldots \ldots A-\ldots$ & $\ldots \ldots$ & $\ldots . \mathrm{T} \ldots$ \\
\hline$-B$ & - & $\cdots$ & & $\ldots \ldots A-\ldots$ & & $\ldots \ldots$ \\
\hline & $\ldots \ldots \ldots$ & $\cdots$ & $\ldots \ldots \ldots$ & $\ldots \ldots A-\ldots$ & $\ldots \ldots \ldots$ & $\ldots \ldots \ldots$ \\
\hline 80 & $\cdots$ & $\ldots$ & $\ldots \ldots \ldots$ & $\ldots \ldots A-\ldots$ & $\ldots \ldots \ldots$ & $\ldots \ldots$ \\
\hline & $\ldots \ldots \ldots$ & $\ldots \ldots$ & $\ldots \ldots \ldots \ldots$ & ... & $\ldots \ldots \ldots$ & $\ldots$. G. \\
\hline 04 & $\ldots$. & $\cdots$ & $\ldots \ldots \ldots$ & $\cdots$ & . & $\ldots \ldots$ \\
\hline 26 & $\ldots \ldots$ & & $\ldots \ldots \ldots$ & $\ldots \ldots A-\ldots$ & $\ldots \ldots \ldots$ & $\ldots \ldots$ \\
\hline 96 & - & $\cdots$ & $\ldots$ & $\cdots$ & $\cdots$ & $\cdots$ \\
\hline & $\cdots$ & & & & & \\
\hline & & $\ldots . \mathrm{T}$ & & $\ldots . . . \mathrm{G} \ldots \mathrm{T}$ & $\ldots \mathrm{CA}$. & $\ldots \mathrm{T} \ldots$ \\
\hline 22 & & & & & & \\
\hline
\end{tabular}

* http://www.nabi.nlm.nih.gov/ 


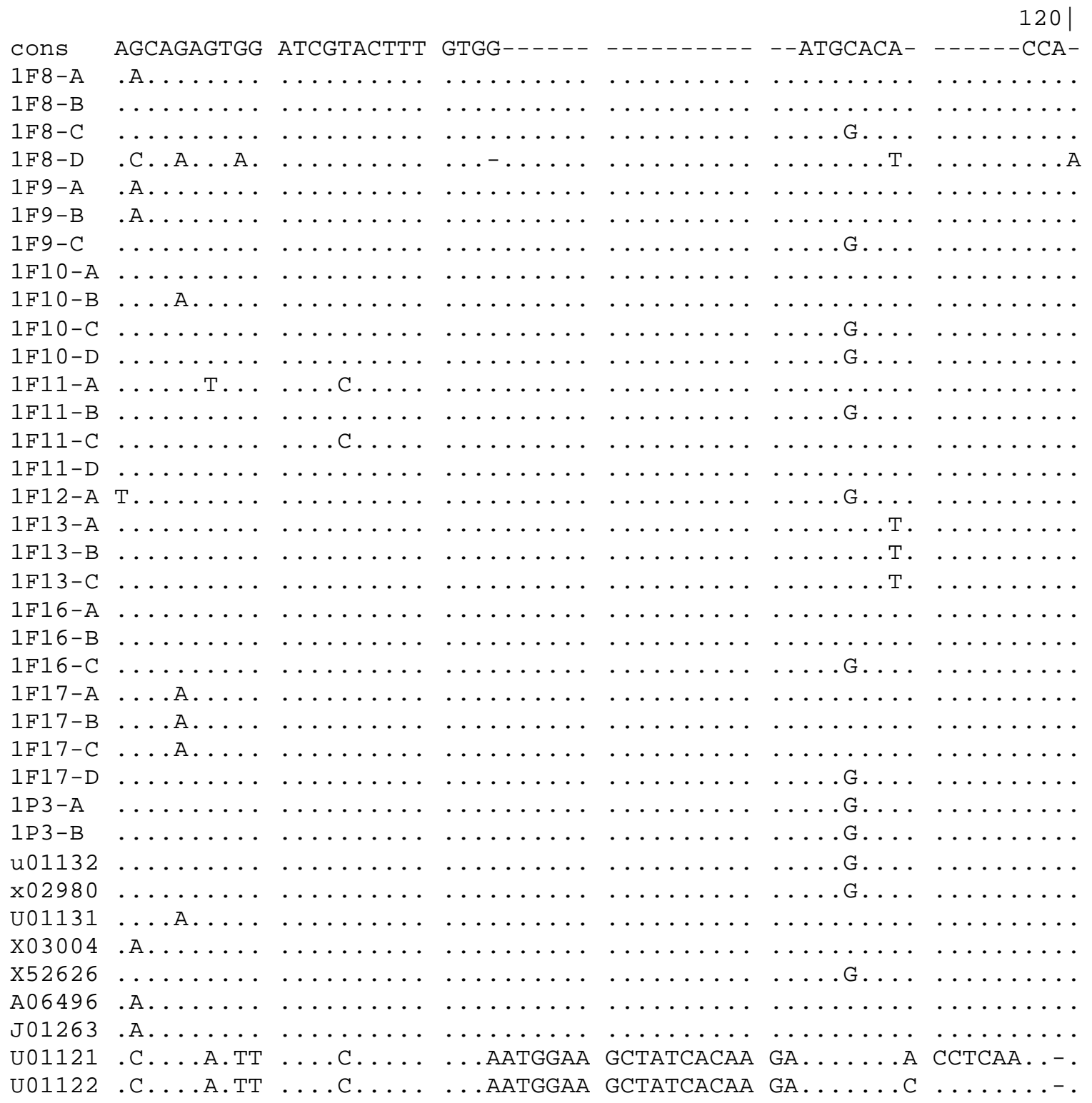




\begin{tabular}{|c|c|c|c|c|c|c|}
\hline & & & & & & \\
\hline & & & & & & 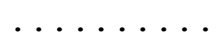 \\
\hline & $\cdots \cdots \cdots$ & $\ldots \ldots \ldots$ & & & & $\ldots \ldots \ldots$ \\
\hline & $\ldots \ldots$ & $\ldots \ldots \ldots$ & $\ldots \ldots \mathrm{TCA}$ & & & GAAG .... \\
\hline & $\ldots \ldots$ & $\ldots \ldots \ldots$ & $\ldots . . . \mathrm{TCA}$ & & & \\
\hline & $\ldots \ldots$ & $\ldots \ldots \ldots$ & $\cdots \cdots \cdots \cdots$ & & & \\
\hline & $\cdots \cdots \cdots$ & & & & & \\
\hline & $\ldots \ldots \ldots$ & & $\ldots \ldots \mathrm{TCA}$ & & & $A A G$ \\
\hline & $\cdots \cdots \cdots$ & $\cdots \cdots \cdots \cdots \cdot$ & & & & \\
\hline & $\ldots \ldots$ & $G \ldots \ldots$ & $\ldots \ldots \ldots$ & 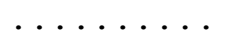 & $\cdots$ & $\cdots$ \\
\hline & $\ldots \ldots$ & $\ldots \ldots$ & $\ldots . . . \mathrm{TCA}$ & GGAA & $A G G$ & GAAG $\ldots$. \\
\hline & $\ldots \ldots$ & $\ldots \ldots \ldots$ & $\ldots$..... & $\cdots \cdots$ & $\ldots \ldots$ & $\cdots \cdots \cdots$ \\
\hline & $\ldots \ldots$ & $\ldots \ldots$ & $\ldots$...... & $\cdots \cdots$ & $\ldots \ldots$ & $\ldots \mathrm{CT} \ldots$ \\
\hline & $\ldots \ldots$ & $\ldots \ldots \ldots$ & $\ldots \ldots \ldots$ & $\cdots \cdots$ & $\cdots$ & $\cdots \cdots \cdots$ \\
\hline & $\ldots \ldots$ & $\ldots \ldots$ & $\ldots \ldots \ldots$ & $\ldots$ & $\cdots$ & $\ldots \ldots$ \\
\hline & $\ldots \ldots G$. & $\ldots \ldots \ldots$ & & & & \\
\hline & & & & & & \\
\hline & $\ldots \ldots$ & $\cdots \cdots \cdots \cdots$ & & & & \\
\hline & & & & & & \\
\hline & • & & & & & \\
\hline & $\ldots \ldots$ & $\ldots \ldots \ldots$ & $\ldots \ldots \ldots$ & $\cdots$ & $\cdots$ & $\cdots \cdots \cdots$ \\
\hline & $\cdots \cdots \cdots \cdots$ & $\cdots \cdots \cdots \cdots$ & $\cdots \cdots \cdots$ & & & \\
\hline & $\ldots \ldots$ & $\ldots \ldots \ldots$ & $\ldots . . . \mathrm{TCA}$ & $\mathrm{BAA}$ & & GAAG $\ldots$. \\
\hline & & • & & & & \\
\hline & $\cdots \cdots$ & $\cdots$ & $\cdots \cdots \cdots$ & $\cdots$ & $\cdots$ & $\cdots \cdots$ \\
\hline & $\cdots \cdots$ & $\cdots \cdots$ & $\cdots-\ldots$ & & & \\
\hline & $\cdots$ & & 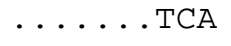 & & & \\
\hline & $\cdots \cdots \cdots$ & $\ldots \ldots$ & $\ldots \ldots \mathrm{T}$ & & & F.... \\
\hline & $\ldots \ldots \ldots$ & $\ldots \ldots \ldots$ & $\ldots \ldots . . . \mathrm{TCA}$ & & & ..... \\
\hline & 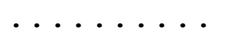 & & $\ldots \ldots$ & & & \\
\hline & $\cdots$ & $\cdot \cdot$ & $\ldots \ldots \mathrm{T}$ & & & GAAG $\ldots$ \\
\hline & & & & $\cdots \cdot$ & $\cdot$ & \\
\hline & $\cdots$ & $\cdots$ & $\cdots \cdots$ & & & \\
\hline & & & CA & GGAA & GG & GAAG • \\
\hline & $\cdots$ & $\cdots$ & $\cdots$ & & & \\
\hline & & & & & & \\
\hline & $\cdots G \ldots$ & $\cdots$ & $\cdot------\ldots$ & $\cdots A$ & & GAAG $\ldots$ \\
\hline & $\ldots G \ldots$ & &.$------\ldots$ & & AGCAAAAGG & GAAG. . \\
\hline
\end{tabular}


$1 \mathrm{~F} 8-\mathrm{A}$

$1 \mathrm{~F} 8-\mathrm{B}$

$1 \mathrm{~F} 8-\mathrm{C}$

$1 \mathrm{~F} 8-\mathrm{D}$

$1 \mathrm{~F} 9-\mathrm{A}$

1F $9-\mathrm{B}$

$1 \mathrm{~F} 9-\mathrm{C}$

1F10-A

$1 \mathrm{~F} 10-\mathrm{B}$

$1 \mathrm{~F} 10-\mathrm{C}$

1F10-D

1F11-A

1F11-B

1F11-C

1F11-D

$1 \mathrm{~F} 12-\mathrm{A}$

$1 \mathrm{~F} 13-\mathrm{A}$

1F13-B

1F13-C

1F16-A

$1 \mathrm{~F} 16-\mathrm{B}$

1F16-C

1F17-A

1F17-B

1F17-C

1F17-D

1P3-A

1P $3-\mathrm{B}$

u 01132

x02980

U01131

$\mathrm{X} 03004$

$\times 52626$

A0 6496

J01263

U01121

U01122

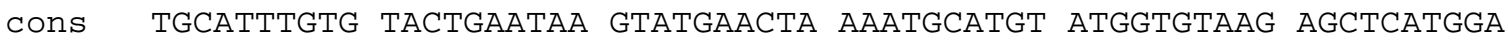
$\ldots \ldots \ldots \ldots \ldots$

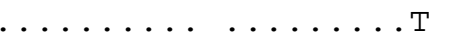

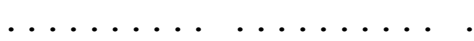

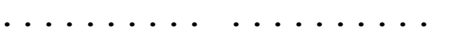

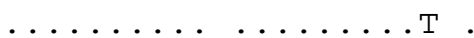

$\ldots \ldots \ldots \ldots \ldots \ldots$

$\ldots \ldots \ldots \ldots \ldots \ldots \ldots$

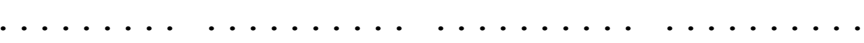

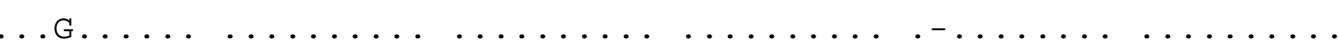

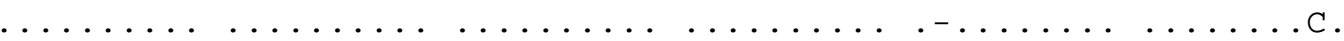

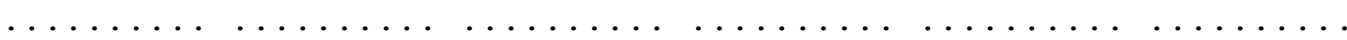

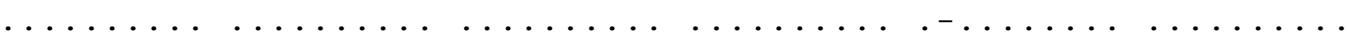

$\ldots \ldots \ldots \ldots \ldots \ldots \ldots \ldots \ldots \ldots \ldots \ldots \ldots \ldots \ldots \ldots \ldots \ldots \ldots \ldots \ldots \ldots \ldots \ldots \ldots \ldots \ldots \ldots$

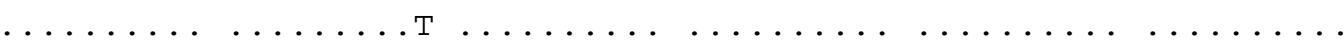

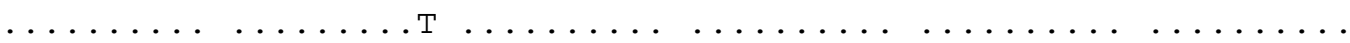

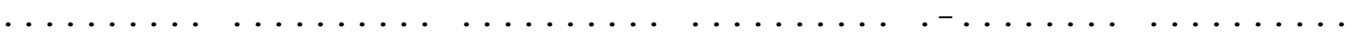

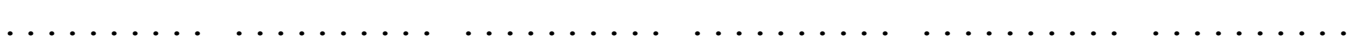

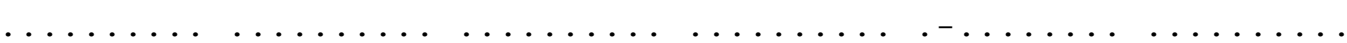

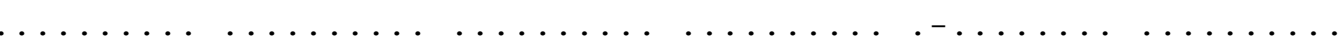

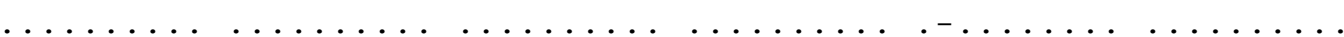

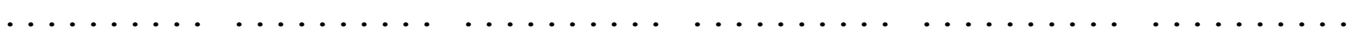

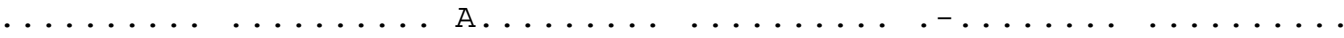

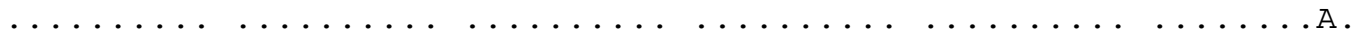

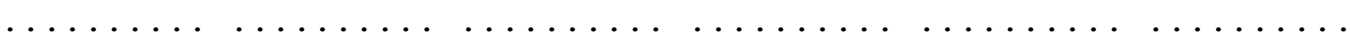

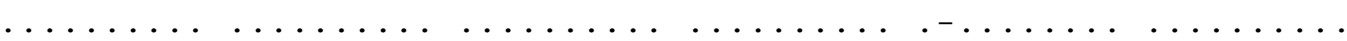

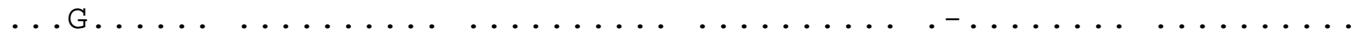

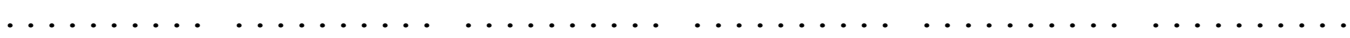

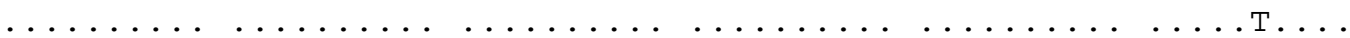

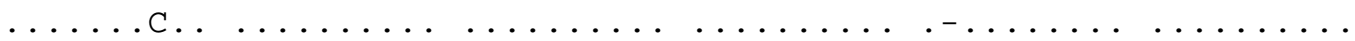

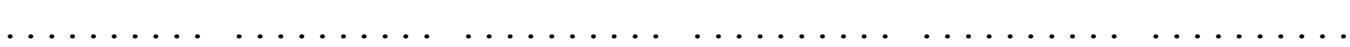

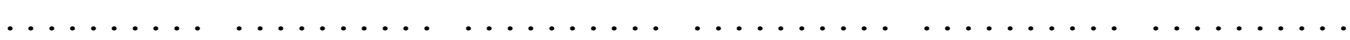

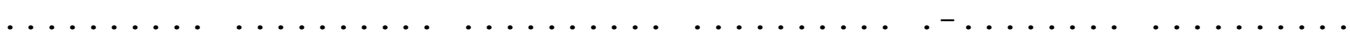

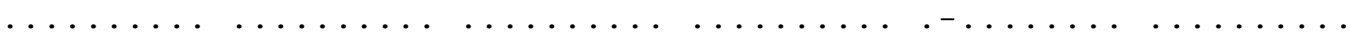

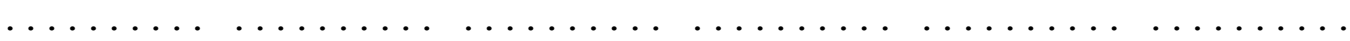

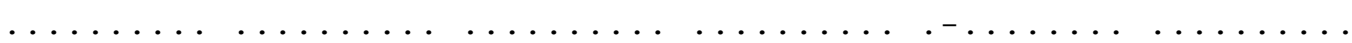

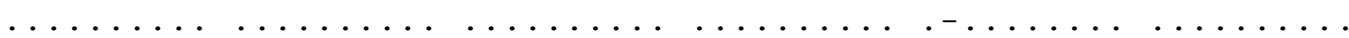

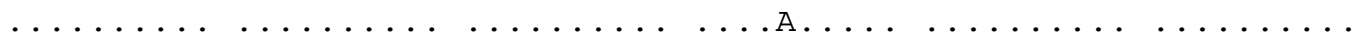

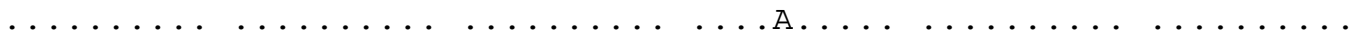


$300 \mid$

\begin{tabular}{|c|c|c|c|c|c|c|}
\hline & & & & & -2 & \\
\hline & $\ldots \ldots \ldots$ & $-\ldots$ Т.... & $\ldots \ldots \ldots$ & $\ldots$. . . . . & e & 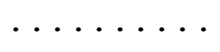 \\
\hline & $\ldots \ldots \ldots$ & $-\ldots \mathrm{T} \ldots$. & $\ldots \ldots \ldots$ & ....G.... & $\ldots \ldots \ldots$ & 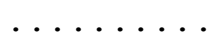 \\
\hline & & $\ldots \ldots \ldots$ & $\ldots \ldots$ & $\ldots \ldots \ldots$ & $\ldots \ldots \ldots$ & $\ldots \ldots \ldots$ \\
\hline & & $\cdots \cdots \cdots$ & $\cdots \cdots \cdots$ & & 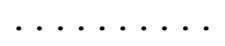 & \\
\hline & & $\ldots$ Т.... & $\ldots \ldots \ldots$ & $\ldots$...... & 西, & \\
\hline & $\cdots \cdots \cdots$ & $\cdots \cdots \cdots$ & $\cdots$ & & 西 & \\
\hline & & & & & $\ldots \ldots \ldots$ & 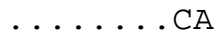 \\
\hline & $\ldots \ldots$ & $-\ldots$ Т.... & & $\ldots$...... & $\ldots \ldots \ldots$ & \\
\hline & $\ldots \ldots$ & $-\ldots$ Т.... & $\ldots \ldots \ldots$ & & $\ldots \ldots \ldots$ & - \\
\hline & $\cdots \cdots \cdots \cdots$ & $\cdots \cdots \cdots \cdots$ & $\ldots \ldots \ldots$ & & $\ldots \ldots \ldots$ & $\cdots \cdots \cdots$ \\
\hline & $\cdots \cdots \cdots$ & $-\ldots$ Т.... & $\cdots \cdots \cdots$ & $\ldots$...... & $\cdots \cdots \cdots$ & $\cdots \cdots \cdots$ \\
\hline & $\ldots \ldots$ & $\ldots \ldots$.... & $\ldots \ldots \ldots$ & $\ldots$ CA.... & $\ldots \ldots \ldots$ & $\ldots \ldots G$ \\
\hline & $\cdots \cdots \cdots$ & $\cdots \cdots \cdots$ & $\cdots \cdots \cdots$ & $\cdots \cdots \cdots$ & $\cdots \cdots \cdots$ & $\cdots \cdots \cdots$ \\
\hline & $\ldots \ldots$ & $\ldots \ldots \ldots$ & $\cdots \cdots$ & $\ldots \ldots$ & $\cdots \cdots \cdots$ & $\cdots$ \\
\hline & $\ldots \ldots \ldots$ & $-\ldots \mathrm{T} \ldots$. & $\ldots \ldots$ & $\ldots$....... & $\cdots \cdots$ & $\cdots$ \\
\hline & & & & & & \\
\hline & & & & $\cdots$ & $H \perp \cdots$ & \\
\hline & & & & & 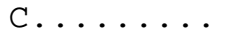 & \\
\hline & - & $\cdots \cdots$ & & $. \mathrm{T} . \mathrm{G}$ & & \\
\hline & $\ldots \ldots$ & $\cdots$ & $\ldots \ldots$ & & $\ldots \ldots \ldots$ & $\cdots \cdots \cdots$ \\
\hline & & & & & & \\
\hline & $\ldots \ldots$ & $\cdots \cdots$ & $\cdots$ & $\cdots$ & $\ldots \ldots \ldots$ & $\cdots$ \\
\hline & $\cdots \cdots \cdots$ & $-\ldots$ Т... & $\cdots$ & $\cdots$ & $\cdots \cdots$ & \\
\hline & $\ldots \ldots \ldots$ & $-\ldots$ Т.... & $c \ldots \ldots$ & $\ldots$....... & $\cdots \ldots \ldots$ & $\cdots \cdots$ \\
\hline & - & $\ldots \ldots$ & $\cdots \cdots$ & $\cdots \cdots \cdots$ & $\cdots \cdots$ & $\cdots$ \\
\hline & $\cdots$ & $\cdots$ & $\cdots$ & $\cdots$ & $\cdots \cdots$ & \\
\hline & $\cdots$ & $\cdots$ & & $\cdots$ & & \\
\hline & & $-\ldots$ & $\cdots$ & & $\cdots$ & \\
\hline & & $\cdots$ & $\cdots$ & & $\cdots$ & $\cdots$ \\
\hline & & $\cdots$ & & $\cdots$ & $\cdots \cdots \cdots$ & $\cdots$ \\
\hline & & & & $\cdots$ & $\cdots \cdots$ & $\cdots$ \\
\hline & & $-\ldots$ & $\cdots \cdots$ & $\ldots G$ & $\cdots \cdots \cdots$ & $\cdots \cdots \cdots$ \\
\hline & & & & & & \\
\hline & & $-\ldots$ & & $\ldots \mathrm{G}$ & $\cdots \cdots \cdots$ & $\cdots \cdots \cdots$ \\
\hline & & & $C \ldots$ & & $\cdots \cdots \cdots$ & $\cdots$ \\
\hline & $\cdots$ & $\cdots \cdot$ & $\cdots \cdots \cdots$ & $\cdots \cdot^{--}$ & $\cdots \cdots \cdots$ & $\cdots \cdots \cdots$ \\
\hline & & & & & & \\
\hline
\end{tabular}




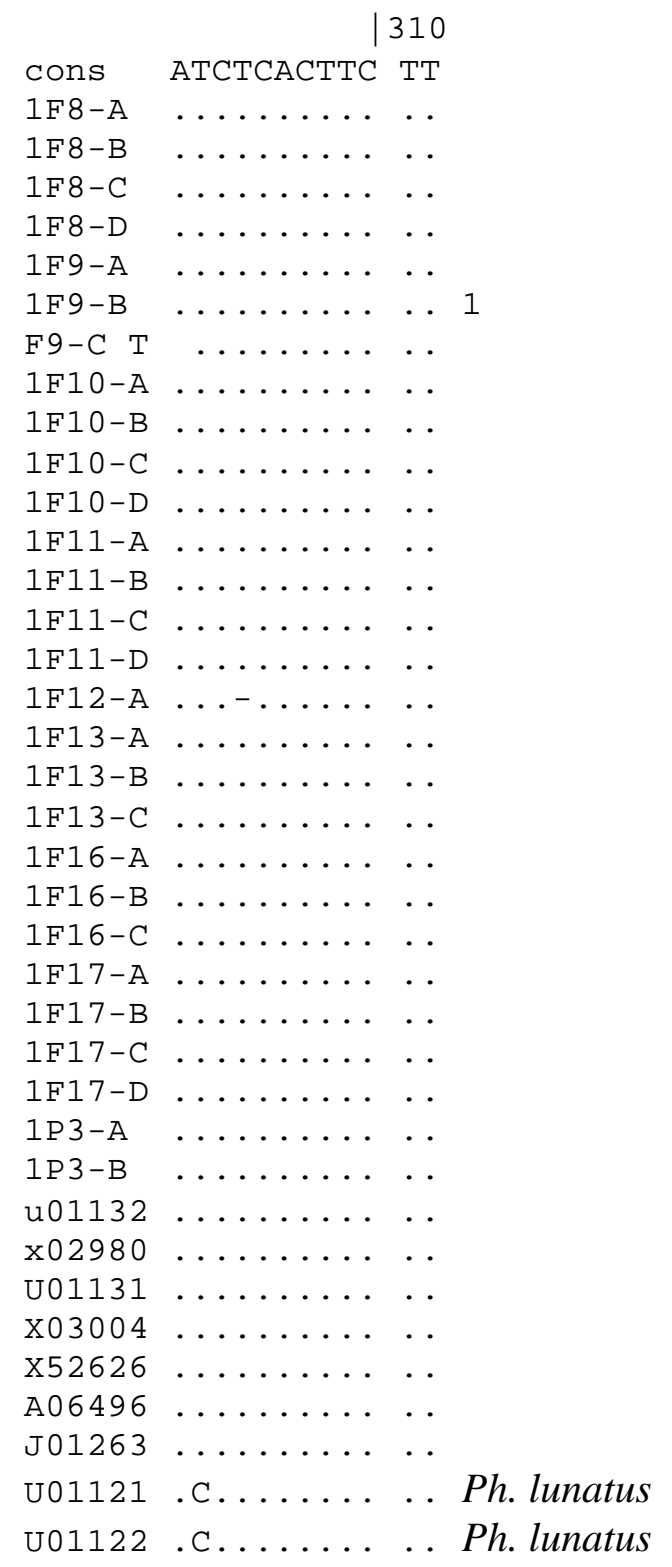


Figura 6. Alinhamento das seqüências do fragmento do gene Phaseolina - PCR 2 em feijão, com seus respectivos alelos. As 15 (quinze) últimas seqüências alinhadas foram obtidas diretamente do banco mundial de sequiências genéticas, sendo que destas, as duas últimas são da espécie $P h$. lunatus, aqui usadas como um "out group"*".

\begin{tabular}{|c|c|c|c|c|c|c|}
\hline CONSEN & ATAGAGCAAA & TT-CGAGGAG & -ATCAACAGG & GTTCTGTTTG & AAGAGGAGGG & ACAGCAA--- \\
\hline $2 \mathrm{p} 3-6$ & $\cdots \cdots \cdots$ & $\cdots \cdots \cdots$ & $\cdots \cdots \cdots$ & $\cdots \cdots \cdots$ & $\cdots \cdots \cdots$ & $\cdots \cdots \cdots$ \\
\hline $2 \mathrm{p} 3-8$ & $-\ldots \ldots$ & $\ldots \ldots \ldots$ & $\ldots \ldots \ldots$ & $\ldots \ldots$ & $\ldots \ldots \ldots$ & $\ldots \ldots$ \\
\hline o3-9 & $\ldots \ldots \ldots$ & $\ldots \ldots \ldots$ & $\ldots \ldots \ldots$ & $\ldots \ldots \ldots$ & $\ldots \ldots \ldots$ & $-\ldots \ldots$ \\
\hline p3-10 & $\ldots \ldots \ldots$ & $\ldots \ldots \ldots$ & $\ldots \ldots \ldots$ & $\ldots \ldots \ldots$ & 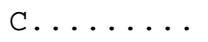 & $\ldots \ldots$ \\
\hline p3-12 & $\cdots \cdots \cdots$ & $\ldots \ldots$ & $\ldots \ldots$ & $\ldots \ldots$ & $\ldots \ldots$ & $\ldots \ldots$ \\
\hline $2 \mathrm{p} 3-13$ & $\ldots \ldots \ldots$ & $\ldots \ldots \ldots$ & $\ldots \ldots \ldots$ & $\ldots \ldots \ldots$ & $\ldots \ldots \ldots$ & $\ldots \ldots \ldots$ \\
\hline $2 F 8-1$ & $\ldots \ldots \ldots$ & $\ldots \ldots \ldots$ & $\ldots \ldots-\ldots$ & $\ldots \ldots \ldots$ & $\ldots \ldots \ldots$ & $\ldots \ldots \ldots$ \\
\hline $8-2$ & $\ldots \ldots \ldots$ & $\ldots \ldots$ & $\ldots \ldots \ldots$ & $\cdots \cdots \cdots$ & $\ldots \ldots \ldots$ & $\ldots \ldots \ldots$ \\
\hline $2 F 8-3$ & $\ldots \ldots \ldots$ & $\ldots \ldots \ldots$ & $\ldots \ldots \ldots$ & $\ldots \ldots \ldots$ & $\ldots \ldots$ & $\ldots \ldots$ \\
\hline $2 \mathrm{~F} 9-3$ & $\ldots \ldots \ldots$ & $\ldots \ldots \ldots$ & $\ldots \ldots \ldots$ & $\ldots \ldots \ldots$ & $\ldots \ldots \ldots$ & $\ldots \ldots \ldots$ \\
\hline $2 \mathrm{~F} 9-4$ & $\cdots \cdots \cdots$ & $\ldots \ldots \ldots$ & $\ldots \ldots \ldots$ & $\cdots \cdots \cdots$ & $\cdots \cdots \cdots$ & $\ldots \ldots \ldots$ \\
\hline 2F10-1 & $\cdots \cdots \cdots$ & $\ldots \ldots \ldots$ & $\ldots \ldots \ldots$ & $\cdots \cdots \cdots$ & $\cdots \cdots \cdots$ & $\ldots \ldots \ldots$ \\
\hline $2 \mathrm{~F} 10-2$ & $\ldots \ldots \ldots$ & $\ldots \ldots \ldots$ & $\ldots \ldots \ldots$ & $\cdots \cdots \cdots$ & $C \ldots \ldots$ & $\cdots \cdots \cdots$ \\
\hline $2 \mathrm{~F} 11-1$ & $\ldots \ldots \ldots$ & $\ldots \ldots \ldots$ & $\ldots \ldots$ & $\ldots \ldots$ & $\ldots \ldots$ & $\ldots \ldots$ \\
\hline $2 \mathrm{~F} 11-2$ & $\cdots-\ldots$ & $\cdots \cdots \cdots$ & $\cdots \cdots \cdots$ & $\cdots \cdots \cdots$ & $\cdots \cdots \cdots$ & $\cdots \cdots \cdots$ \\
\hline $2 \mathrm{~F} 11-3$ & $\ldots \ldots$ & $\ldots \ldots$ & $\ldots \ldots$ & $\ldots \ldots \ldots$ & $\ldots \ldots \ldots$ & $\cdots \cdots \cdots$ \\
\hline $1-4$ & $\ldots \ldots$ & $\cdots \cdots \cdots$ & $\ldots \ldots$ & $\cdots \cdots \cdots$ & $\cdots \cdots \cdots$ & $\ldots \ldots \ldots$ \\
\hline $12-3$ & $\ldots \ldots \ldots$ & $\cdots \cdots \cdots$ & $\cdots \cdots \cdots$ & $\cdots \cdots \cdots$ & $\cdots \cdots \cdots$ & $\cdots \cdots \cdots$ \\
\hline $3-2$ & $\ldots \ldots \ldots$ & $\cdots \cdots \cdots$ & $\cdots \cdots \cdots$ & $\cdots \cdots \cdots$ & $\cdots \cdots \cdots$ & $\cdots \cdots \cdots$ \\
\hline $4-1$ & $\ldots \ldots \ldots$ & $\cdots \cdots \cdots$ & $\cdots \cdots \cdots$ & $\cdots \cdots \cdots$ & $\cdots \cdots \cdots$ & $\cdots \cdots \cdots$ \\
\hline $2 \mathrm{~F} 14-2$ & $\cdots$ & $\ldots \ldots \ldots$ & $\cdots \cdots \cdot$ & $\cdots \cdots \cdots$ & $\cdots \cdots \cdots$ & $\cdots \cdots \cdots$ \\
\hline $2 F 15-1$ & $\ldots \ldots \ldots$ & $\cdots \cdots \cdots$ & $\cdots \cdots \cdots$ & $\cdots \cdots \cdots$ & $\cdots \cdots \cdot$ & $\cdots \cdots \cdots$ \\
\hline $2 \mathrm{~F} 15-2$ & $\cdots$ & $\cdots \cdots$ & & $\cdots \cdots \cdots$ & & \\
\hline $2 \mathrm{~F} 15-3$ & $\cdots$ & $\cdots \cdots$ & $\cdots \cdots \cdot$ & $\cdots \cdots \cdots$ & $\cdots \cdots \cdot$ & $\cdots \cdots$ \\
\hline $2 F 15-4$ & $\cdots$ & $\cdots \cdots$ & $\cdots$ & $\cdots \cdots$ & $\cdots \cdots$ & $\cdots \cdots$ \\
\hline $2 \mathrm{~F} 16-3$ & $\cdots \cdots \cdots$ & $\cdots \cdots \cdots$ & $\cdots \cdots \cdots$ & $\cdots \cdots \cdots$ & $\cdots \cdots \cdots$ & $\cdots \cdots \cdots$ \\
\hline $2 \mathrm{~F} 16-4$ & $\cdots \cdots \cdots$ & $\cdots \cdots \cdots$ & $\cdots \cdots$ & $\ldots \ldots \ldots$ & $\ldots \ldots \ldots$ & $\ldots \ldots \ldots$ \\
\hline $2 F 16-5$ & $\ldots-\ldots \ldots$ & $\ldots \ldots \ldots$ & $\ldots \ldots \ldots$ & $\ldots \ldots \ldots$ & $\ldots \ldots \ldots$ & $\cdots \cdots \cdots$ \\
\hline $2 \mathrm{~F} 16-6$ & $\ldots \ldots \ldots$ & $\cdots \cdots \cdots$ & $\ldots \ldots$ & $\ldots \ldots$ & $\ldots \ldots \ldots$ & $\ldots$..... \\
\hline $2 \mathrm{~F} 17-3$ & $\cdots \cdots \cdots$ & $\cdots \cdots \cdots$ & $\cdots \cdots \cdots$ & $\cdots \cdots \cdots$ & 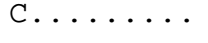 & $\cdots \cdots \cdots$ \\
\hline $2 \mathrm{~F} 17-4$ & $\ldots \ldots \ldots$ & $\cdots \cdots \cdots$ & $\cdots \cdots \cdots$ & $\cdots \cdots \cdots$ & $\cdots \cdots \cdots$ & $\cdots \cdots \cdots$ \\
\hline $2 F 17-5$ & $\cdots \cdots \cdots$ & $\cdots \cdots \cdots$ & $\cdots \cdots \cdots$ & $\cdots \cdots \cdots$ & $\cdots \cdots \cdots$ & $\cdots$. . . \\
\hline $2 \mathrm{~F} 17-6$ & $\cdots \cdot$ & $\cdots \cdots \cdots$ & $\cdots \cdots \cdots$ & $\cdots \cdots \cdots$ & $\cdots \cdots$ & $\cdots \cdots \cdots$ \\
\hline$\times 52626$ & $\cdots$ & $\cdots \cdots$ & $\cdots \cdots$ & $\cdots \cdots$ & $\cdots$ & $\cdots \cdots \cdots$ \\
\hline & ---- & $\cdots \cdots \cdots$ & $\cdots \cdots$ & $\cdots \cdots \cdots$ & 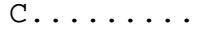 & $\cdots \cdots \cdots$ \\
\hline 31 & --- & & & & & \\
\hline 04 & ---- & & & $\cdots \cdots \cdots$ & $\cdots \cdots \cdot$ & $\cdots$ \\
\hline 96 & & $\cdots \cdots$ & & $\cdots \cdot$ & & $\cdots \cdots \cdots$ \\
\hline 23 & & $\cdots \cdots$ & $\cdots \cdots \cdot$ & $\cdots \cdots \cdots$ & & $\cdots \cdot$ \\
\hline & $\cdots \cdot$ & $\cdots \cdots$ & & $\cdots \cdots \cdots$ & $\cdots$ & $\cdots \cdots$ \\
\hline & & & & & & \\
\hline X02980 & $\ldots$ & & & & & \\
\hline J01263 & $\cdots \cdots$ & $\cdots \cdots$ & $\cdots \cdots$ & $\ldots \ldots \ldots$ & & . GAG \\
\hline u01130 & $\cdots$ & $\ldots \ldots$ & $\ldots \ldots$ & $\ldots \ldots \ldots$ & & ...GAG \\
\hline 1129 & $\cdots \cdot$ & $\cdots \cdots$ & $\ldots \ldots$ & $\ldots \ldots$ & $\ldots \ldots \ldots$ & $\ldots \ldots \mathrm{GAG}$ \\
\hline 121 & ---- & & $\cdots$ & & $C \ldots$. & $\ldots G \ldots$ \\
\hline 22 & $---\ldots \mathrm{CC}$ & 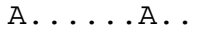 & $\ldots \mathrm{T} \ldots$ & $\ldots \ldots \ldots$ & & \\
\hline
\end{tabular}

\footnotetext{
* http://www.nabi.nlm.nih.gov/
} 


\begin{tabular}{|c|c|c|c|c|c|c|}
\hline CONSEN & -ーーーー-ーーーー & -- GAGGGAGT & AATGTGAAC & TTGATT-CT & AACAGATTA & $A G G A A C I G A G$ \\
\hline $2 \mathrm{p} 3-6$ & $\cdots \cdots \cdots$ & $\cdots \cdots \cdots$ & $\cdots \cdots \cdots$ & $\cdots \cdots \cdots$ & $\cdots \cdots \cdots \cdot$ & $\cdots \cdots \cdots$ \\
\hline $3-8$ & $\cdots \cdots \cdots \cdots$ & $\cdots \cdots \cdots$ & $\cdots \cdots \cdots \cdots$ & $\ldots \ldots$ & $\ldots \ldots G$ & $\cdots \cdots \cdots \cdots$ \\
\hline & $\cdots \cdots \cdot \cdots$ & $\cdots \cdots$ & $\cdots \cdots \cdots \cdot$ & $\cdots \cdots \cdots$ & $\cdots-\ldots$ & $\cdots \cdots \cdots \cdots$ \\
\hline & $\ldots \ldots$ & $\ldots \ldots$ & $\cdots \cdots \cdots$ & $\ldots \ldots \ldots$ & $\ldots \ldots G$ & $\cdots \cdots \cdots$ \\
\hline-12 & $\cdots \cdots \cdots \cdots$ & $\cdots \cdots \cdots$ & $\cdots \cdots \cdots \cdots$ & $\ldots \ldots$ & $\ldots \ldots$ & $\cdots \cdots \cdots$ \\
\hline-13 & $\ldots \ldots$ & $\ldots \ldots \ldots$ & $\cdots \cdots \cdots$ & $\ldots \ldots$ & $\ldots \ldots$ & $\cdots \cdots \cdots$ \\
\hline & $\ldots \ldots$ & $\ldots A$ A... & $\cdots \cdots$ & $\ldots \ldots$ & $\ldots \ldots$ & $\cdots \cdots \cdots \cdot$ \\
\hline & $\cdots \cdots \cdots \cdots$ & $\ldots \ldots \ldots$ & $\ldots \ldots$ & $\ldots \ldots \ldots$ & $\ldots \ldots$ & $\ldots \ldots$ \\
\hline & $\ldots \ldots \ldots$ & $\ldots \ldots \ldots$ & $\ldots \ldots \ldots$ & $\ldots \ldots \ldots$ & $\ldots \ldots$ & $\ldots \ldots$ \\
\hline & $\cdots \cdots \cdots$ & $\ldots \ldots$ & $\ldots \ldots$ & $\cdots \cdots \cdots$ & $\ldots \ldots$ & $\cdots \cdots \cdots$ \\
\hline & $\ldots \ldots \ldots$ & $\ldots \ldots \ldots$ & $\ldots \ldots \ldots$ & $\ldots \ldots \ldots$ & $\ldots \ldots$ & $\ldots \ldots$ \\
\hline & $\ldots \ldots \ldots$ & $\ldots \ldots \ldots$ & $\cdots \cdots$ & $\ldots \ldots \ldots$ & $\cdots \cdots \cdots$ & $\cdots \cdots \cdots$ \\
\hline-2 & $\ldots \ldots$ & $\ldots \ldots \ldots$ & $\ldots \ldots \ldots$ & $\ldots \ldots \ldots$ & $\cdots \cdots \cdot \cdots$ & $\ldots \ldots$ \\
\hline-1 & $\cdots \cdots \cdots$ & $\ldots \ldots \ldots$ & $\ldots \ldots \ldots$ & $\cdots \cdots \cdots$ & $\cdots \cdots \cdots$ & $\cdots \cdots \cdots$ \\
\hline & $\ldots \ldots$ & $\cdots \cdots \cdots$ & $\ldots \cdots \cdots$ & $\ldots \ldots \ldots$ & $\cdots \cdots \cdots$ & $\cdots \cdots \cdots$ \\
\hline-3 & $\cdots \cdots \cdots$ & $\cdots \cdots$ & $\cdots \cdots \cdots$ & $\cdots \cdots \cdots$ & $\cdots \cdots \cdots$ & $\cdots \cdots \cdots$ \\
\hline-4 & $\ldots \ldots$ & $\ldots \ldots \ldots$ & $\ldots \ldots \ldots$ & $\ldots \ldots \ldots$ & $\cdots \cdots \cdot$ & $\cdots \cdots \cdots$ \\
\hline$J$ & $\ldots \ldots$ & $\ldots \ldots$ & $\cdots \cdots \cdots$ & $\ldots \ldots$ & $\cdots \cdots \cdot$ & $\cdots \cdots \cdot$ \\
\hline-2 & $\cdots \cdots \cdots$ & $\ldots \ldots \ldots$ & $\cdots \cdots \cdot$ & $\cdots \cdots \cdot$ & $\cdots \cdots \cdots$ & $\cdots \cdots \cdots$ \\
\hline-1 & $\ldots \ldots$ & $\ldots \ldots$ & $\ldots \ldots$ & $\ldots \ldots$ & $\ldots \ldots \mathrm{G}$ & $\ldots \ldots \cdots$ \\
\hline-2 & $\ldots \ldots$ & $\cdots \cdots$ & $\cdots \cdots$ & $\ldots \ldots \ldots$ & $\cdots \cdots \cdots$ & $\ldots \cdots \cdots$ \\
\hline-1 & $\cdots \cdots \cdots$ & $\ldots \ldots \cdots$ & $\cdots \cdots \cdots$ & $\cdots \cdots \cdots$ & $\cdots-\ldots$ & $\cdots \cdots \cdots$ \\
\hline-2 & $\ldots \ldots$ & $\cdots \cdots \cdots$ & $\cdots \cdots \cdots$ & $\ldots \ldots$ & $\ldots \ldots$ & $\cdots \cdots \cdots$ \\
\hline-3 & $\ldots \ldots$ & $\ldots \ldots$ & $\cdots \cdots \cdot$ & $\cdots \cdots \cdots$ & $\cdots$ & $\cdots \cdots \cdots$ \\
\hline-4 & $\ldots \ldots$ & $\ldots \ldots \ldots$ & $\ldots \ldots \ldots$ & $\cdots \cdots \cdots$ & $\cdots \cdots \cdots$ & $\ldots \cdots \cdots$ \\
\hline-3 & $\ldots \ldots$ & $\ldots \ldots$ & $\ldots \ldots \ldots$ & $\ldots \ldots \ldots$ & $\ldots \ldots$ & $\ldots \ldots$ \\
\hline-4 & $\ldots \ldots$ & $\ldots \ldots$ & $\ldots \ldots \ldots$ & $\ldots \ldots$ & $\ldots \ldots \mathrm{G}$ & $\ldots \ldots$ \\
\hline-5 & $\cdots \cdots \cdots \cdot$ & $\cdots \cdots \cdot$ & $\cdots \cdots \cdot$ & $\cdots \cdots \cdot$ & $\cdots \cdots \cdots$ & $\cdots \cdots \cdots$ \\
\hline-6 & $\ldots \ldots$ & $\ldots \ldots$ & $\ldots \ldots \ldots$ & $\ldots \ldots \ldots$ & $\ldots \ldots$ & $\ldots \ldots$ \\
\hline-3 & $\ldots \ldots \ldots$ & $\ldots \ldots \ldots$ & $\ldots \ldots \ldots$ & $\ldots \ldots \ldots$ & $\cdots \cdots G$ & $\cdots \cdots \cdots$ \\
\hline-4 & $\ldots \ldots$ & $\ldots \ldots \ldots$ & $\ldots \ldots \ldots$ & $\ldots \ldots \ldots$ & $\ldots \ldots$ & $\ldots \ldots$ \\
\hline-5 & $\ldots \ldots \cdots$ & $\ldots \ldots \ldots$ & $\ldots \ldots \ldots$ & $\ldots \ldots \ldots$ & $\ldots \ldots \ldots$ & $\cdots \cdots \cdots$ \\
\hline-6 & $\ldots \ldots \ldots$ & $\ldots \ldots \ldots$ & $\ldots \ldots \ldots$ & $\ldots \ldots \ldots$ & $\ldots \ldots G$ & $\ldots \ldots$ \\
\hline 26 & $\ldots \ldots$ & $\ldots \ldots \ldots$ & $\ldots \ldots \ldots$ & $\ldots \ldots \ldots$ & $\ldots \ldots G$ & $\ldots \ldots$ \\
\hline 32 & $\cdots \cdots \cdots$ & $\cdots \cdots \cdots$ & $\cdots \cdots \cdots$ & $\cdots \cdots \cdots$ & $\ldots \ldots G$ & $\cdots \cdots \cdots$ \\
\hline & 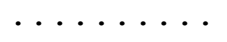 & $\ldots \ldots \ldots$ & $\ldots \ldots \ldots$ & $\ldots \ldots \ldots$ & $\ldots \ldots \ldots$ & $\ldots \ldots \ldots$ \\
\hline & $\cdots \cdots$ & $\ldots \ldots$ & $\ldots \ldots \ldots$ & $\ldots \ldots \ldots$ & $\ldots \ldots \ldots$ & $\ldots \ldots$ \\
\hline & $\ldots \ldots \ldots$ & $\cdots \cdots \cdot$ & $\ldots \ldots \ldots$ & $\ldots \ldots \ldots$ & $\cdots \cdot$ & $\ldots \ldots$ \\
\hline & $\ldots \cdots \cdots$ & - & $\cdots \cdots$ & $\cdots \cdots$ & $\cdots \cdots \mathrm{G}$ & $\ldots \ldots$ \\
\hline & & & $\ldots \ldots \cdots$ & $\ldots \ldots \ldots$ & $\ldots \ldots G$ & $\ldots \ldots \cdots$ \\
\hline 27 & & & $\ldots \ldots \mathrm{T}$ & $\mathrm{T} \ldots \ldots$ & $\ldots \ldots G$ & $\ldots \ldots$ \\
\hline & $\cdot$ & & $\cdots \cdots$ & $\cdots \cdots \cdot$ & $\ldots \ldots \mathrm{G}$ & $\ldots \ldots$ \\
\hline & GAGGGACAGC & $A A \ldots$ & & $\cdots \cdots$ & $\ldots \ldots \mathrm{G}$ & $\ldots \ldots \ldots$ \\
\hline 63 & GAGGGACAGC & $\mathrm{AA}$ & - & - & $\cdots$ & $\ldots \ldots \ldots$ \\
\hline & GAGGG & & -・ & $\ldots . \mathrm{G}$ & $\cdots \cdot \cdot$ & $\cdots \cdots \cdots$ \\
\hline 29 & GAGGGACACG & & & $\cdots \cdots \cdots$ & $\ldots \ldots \mathrm{G}$ & $\ldots \ldots$ \\
\hline & $\cdots \cdots \cdots$ & & & $\ldots \mathrm{GA} \ldots \mathrm{G}$ & $\ldots \mathrm{T} . \mathrm{T} \ldots \mathrm{C}$ & $\cdots \cdots \cdot$ \\
\hline & & & & $\ldots \mathrm{GA} \ldots \mathrm{G}$ & $\ldots \mathrm{T} \cdot \mathrm{T} \ldots \mathrm{C}$ & \\
\hline
\end{tabular}


CONSEN CA-AACATGC AAAATCTAGT TCAAGG-AAA TCCCTTT-CC AAACAAGATA ACAC-AATTG

\begin{tabular}{|c|c|c|c|c|c|c|}
\hline 3-6 & $\cdots \cdot \cdot \cdot \cdot \cdot$ & $\cdots \cdots \cdots$ & $\cdots \cdots \cdots \cdots$ & $\cdots A \cdots$ & $\cdots \cdots \cdots \cdots$ & $\cdots \cdot \cdots \cdot \cdot$ \\
\hline $3-8$ & $\cdots \cdots \cdots$ & $\cdots \cdots \cdots$ & $\cdots \cdots \cdots$ & . T.A.... & $\cdots \cdots \cdots$ & $\cdots \cdots \cdots \cdot$ \\
\hline $3-9$ & $\bullet \bullet \bullet ・ ・ \bullet$ & $\cdots \cdots \cdots \cdot$ & $\cdots \cdots \cdots$ & $\cdots \cdots \cdots \cdots$ & $\cdots \cdots \cdots$ & $\cdots \cdots \cdots$ \\
\hline-10 & $\cdots \cdots \cdots$ & $\cdots \cdots \cdots$ & $\cdots \cdots \cdots$ & $\ldots \ldots$ & $\ldots \ldots$ & $\ldots \ldots$ \\
\hline-12 & $\cdots \cdots \cdots \cdot \bullet$ & $\cdots \cdots \cdots \cdots$ & $\cdots \cdots \cdots \cdots$ & $\ldots \ldots \ldots$ & $\ldots \ldots$ & $\cdots \cdots \cdot \cdots \cdot$ \\
\hline-13 & $\cdots \cdots \cdots$ & $\cdots \cdots \cdots$ & $\ldots \ldots \ldots$ & $\ldots \ldots \ldots$ & $\ldots \ldots$ & $\ldots \ldots$ \\
\hline & $\cdots \cdots \cdots$ & $\ldots \ldots$ & $\ldots . .$. & $\ldots \ldots \ldots$ & $\ldots \ldots$ & $\cdots \cdots \cdots$ \\
\hline & $\cdots \cdots \cdots$ & $\ldots \ldots$ & $\ldots$..... & $\ldots \ldots$ & $\ldots \ldots$ & $\cdots \cdots \cdots$ \\
\hline & $\cdots \cdots \cdots$ & $\ldots \ldots \ldots$ & $\cdots \cdots \cdots$ & $\ldots \ldots \ldots$ & $\ldots \ldots$ & $\ldots \ldots$ \\
\hline & $\cdots \cdots \cdot \cdots$ & $\ldots \ldots$ & $\ldots \ldots$ & $\ldots \ldots \ldots$ & $\ldots \ldots$ & $\ldots \ldots$ \\
\hline & $\ldots \mathrm{C} \ldots \ldots$ & $\cdots \cdots \cdots$ & $\ldots \ldots \cdots$ & $\cdots \cdots \cdots$ & $\cdots \cdots \cdots$ & $\ldots \ldots$ \\
\hline & $\cdots \cdots \cdots$ & $\ldots \ldots \ldots$ & $\cdots \cdots \cdots$ & $\ldots \ldots \ldots$ & $\ldots \ldots$ & $\ldots \ldots$ \\
\hline-2 & $\cdots \cdots \cdots$ & $\ldots \ldots \ldots$ & $\ldots \ldots \ldots$ & $\ldots \ldots$ & $\ldots \ldots$ & $\ldots \ldots$ \\
\hline & $\ldots \ldots \ldots$ & $\ldots \ldots$ & $\ldots \ldots \ldots$ & $\ldots \ldots$ & $\ldots \ldots$ & $\ldots \ldots$ \\
\hline-2 & $\cdots \cdots \cdots$ & $\ldots \ldots$ & $\cdots \cdots \cdots$ & $\ldots \ldots \ldots$ & $\ldots \ldots$ & $\ldots \ldots$ \\
\hline-3 & $\cdots \cdots \cdots$ & $\ldots \ldots \ldots$ & $\cdots \cdots \cdots$ & $\cdots \cdot$ & $\cdots$ & $\ldots \ldots$ \\
\hline-4 & $\ldots \cdots \cdots$ & $\ldots \ldots \ldots$ & $\ldots \ldots \ldots$ & $\ldots \ldots \ldots$ & $\ldots \ldots$ & $\ldots \ldots$ \\
\hline-3 & $\ldots \ldots$ & $\ldots \ldots$ & $\ldots \ldots$ & $\ldots \ldots$ & $\ldots \ldots$ & $\ldots \ldots$ \\
\hline-2 & $\cdots \cdots \cdots \cdot$ & $\ldots \ldots$ & $\ldots \ldots \ldots$ & $\ldots \ldots$ & $\ldots \ldots$ & $\ldots \ldots$ \\
\hline-1 & $\ldots \ldots$ & $\ldots \ldots$ & $\ldots \ldots$ & $\ldots$ A.... & $\ldots \ldots$ & $\ldots \ldots \cdots$ \\
\hline-2 & $\cdots \cdots$ & $\ldots \ldots \ldots$ & $\ldots \ldots \ldots$ & $\ldots \ldots$ & $\ldots \ldots$ & $\ldots \ldots$ \\
\hline-1 & $\ldots \ldots$ & $\ldots \ldots$ & $\ldots \ldots \ldots$ & $\ldots \ldots \ldots$ & $\ldots \ldots$ & $\cdots \cdots \cdots$ \\
\hline-2 & $\ldots \ldots$ & $\ldots \ldots$ & $\cdots \cdots \cdots$ & $\ldots \ldots \ldots$ & $\cdots \cdots \cdots$ & $\cdots \cdots \cdots$ \\
\hline-3 & $\cdots \cdot \cdot$ & $\cdots \cdots \cdots$ & $\cdots \cdots \cdots$ & $\cdots \cdot$ & $\cdots \cdot \cdot$ & $\cdots \cdots \cdots \cdots$ \\
\hline-4 & $\cdots \cdots \cdots$ & $\ldots \ldots$ & $\ldots \ldots \ldots$ & $\cdots \cdot \cdot$ & $\ldots \ldots$ & $\cdots \cdots \cdots$ \\
\hline-3 & $\ldots \ldots$ & $\ldots \ldots$ & $\cdots \cdots \cdots$ & $\cdots \cdots \cdots$ & $\cdots \cdots \cdots$ & $\cdots \cdots \cdots$ \\
\hline-4 & $\ldots \ldots$ & $\ldots \ldots \ldots$ & $\ldots \ldots \ldots$ & $\ldots \ldots$ & $\ldots \ldots$ & $\ldots \ldots$ \\
\hline-5 & $\cdots \cdots \cdots \cdots$ & $\ldots \ldots \ldots$ & $\cdots \cdots \cdots \cdots$ & $\ldots \ldots$ & $\ldots \ldots$ & $\cdots \cdots \cdots$ \\
\hline $5-6$ & $\ldots \ldots$ & $\ldots \ldots \ldots$ & $\ldots \ldots \ldots$ & $\ldots \ldots \ldots$ & $\ldots \ldots$ & $\ldots \ldots$ \\
\hline-3 & $\cdots \cdots \cdots$ & $\ldots \ldots \ldots$ & $\cdots \cdots \cdots$ & $\cdots \cdots \cdots$ & $\cdots \cdots \cdots$ & $\ldots \ldots$ \\
\hline-4 & $\ldots \ldots$ & $\ldots \ldots \ldots$ & $\ldots \ldots \ldots$ & $\ldots \ldots \ldots$ & $\ldots \ldots$ & $\ldots \ldots \ldots$ \\
\hline-5 & $\ldots \ldots \ldots$ & $\ldots \ldots \ldots$ & $\ldots \ldots \ldots$ & $\ldots \ldots \ldots$ & $\ldots \ldots$ & $\ldots \ldots$ \\
\hline $7-6$ & $\ldots \ldots$ & $\ldots \ldots \ldots$ & $\ldots \ldots \ldots$ & $\ldots \ldots \ldots$ & $\ldots \ldots$ & $\ldots \ldots$ \\
\hline 26 & $\cdots \cdots \cdots \cdots$ & $\ldots \ldots$ & $\ldots \ldots \ldots$ & $\cdots \cdots \cdots$ & $\ldots \ldots$ & $\ldots \ldots$ \\
\hline 32 & $\ldots \ldots$ & $\ldots \ldots \ldots$ & $\ldots \ldots \ldots$ & $\ldots \ldots \ldots$ & $\ldots \ldots$ & $\ldots \ldots$ \\
\hline 31 & $\cdots \cdots \cdots \cdot$ & $\ldots \ldots \ldots$ & $\ldots \ldots \ldots$ & $\ldots \ldots \ldots$ & $\ldots \ldots$ & $\ldots \ldots$ \\
\hline 04 & $\cdots \cdots$ & $\ldots \ldots \ldots$ & $\ldots \ldots \ldots$ & $\cdots$ & $\ldots \ldots$ & $\ldots \ldots$ \\
\hline 96 & . & $\cdots \cdot \cdot$ & $\ldots \ldots \ldots$ & $\cdots \cdot$ & $\ldots \ldots$ & $\ldots \ldots$ \\
\hline & 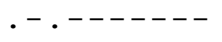 & --- & $---\cdot---$ & ----- & ---- &.--------- \\
\hline 28 & $\cdot-\cdot-------$ & ----- & $------\cdot---$ &.--------- & ---- & $----\cdot--$ \\
\hline 127 & $\cdot-\cdot-------$ & ---------- &.--------- &.--------- & -ー-ー-ー-ー- & $----\cdot---$ \\
\hline 26 &.- & & $---\cdot---$ &.---- & ------ & $----\cdot--$ \\
\hline 80 & & $\cdots \cdot \cdot$ & $\cdots \cdots \cdots ・$ & $\ldots A$ & $\cdots \cdot$ & $\cdots \cdots \cdots$ \\
\hline 63 & $\cdots$ & & $\cdots$ & $\cdots \cdot$ & $\cdots \cdots$ & $\ldots \ldots \cdots$ \\
\hline & $\cdot-\cdot---$ & -- & $--\cdot---$ & $--\cdot--$ & ------ & $----\cdot--$ \\
\hline 29 & $\cdot-\cdot-------$ & ---------- & $------\cdot---$ & $-------\cdot--$ & ------ & $----\cdot \cdot--$ \\
\hline & $\cdots$ & & & A. & --- & $\cdots \mathrm{T} \cdot \mathrm{C}-$ \\
\hline 2 & $\cdots G \ldots \cdot \cdots$ & C $\cdots \cdots \cdots$ & & & & $\cdots \mathrm{T} \cdot \mathrm{C}-\ldots$ \\
\hline
\end{tabular}


CONSEN GAAA----- -CGAATTTGg AAACCT-GAC TGAGAGG-AC CGATAACTCC TTGAATGTGT

$2 \mathrm{p} 3-6$

$2 \mathrm{p} 3-8$

$2 \mathrm{p} 3-9$

$2 \mathrm{p} 3-10$

$2 \mathrm{p} 3-12$

2p3-13

2F 8-1

2F 8-2

$2 \mathrm{~F} 8-3$

2F $9-3$

2F 9-4

2F 10-1

2F10-2

2F11-1

2F11-2

2F11-3

2F11-4

2F $12-3$

2F13-2

2F14-1

2F14-2

2F 15-1

2F15-2

2F15-3

2F15-4

2F $16-3$

2F16-4

$2 \mathrm{~F} 16-5$

$2 \mathrm{~F} 16-6$

2F17-3

2F17-4

2F17-5

2F17-6

$\times 52626$

u 01132

U01131

$\mathrm{x} 03004$

a 06496

u01123

U01128

u01127

U01126

X02980

J01263

u 01130

u 01129

u 01121

u 01122

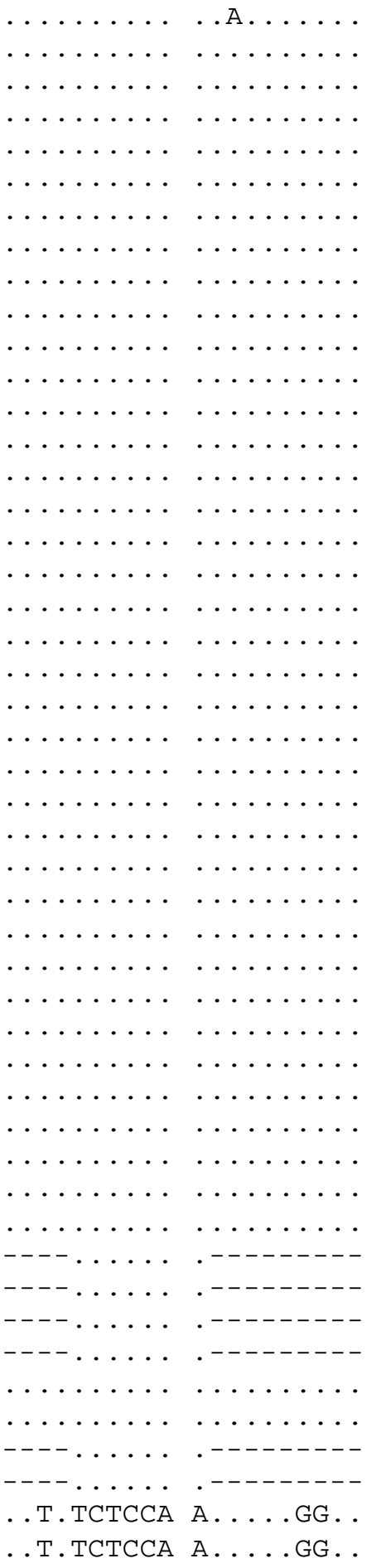


CONSEN TAATCAG--T TCTATAgAgA TGAAAgAgGt AAAtACAAAg AAAAACCAT

\begin{tabular}{|c|c|c|c|c|c|}
\hline $\begin{array}{l}2 p 3-6 \\
2 p 3-8\end{array}$ & $\cdots \cdots$ & $\cdots \cdots \cdots$ & $\cdots \cdots \cdots$ & $\cdots \cdots \cdots$ & $\ldots \ldots \ldots$ \\
\hline $2 p 3-9$ & $\ldots \ldots \ldots$ & $\ldots \ldots \ldots$ & $\ldots \ldots \ldots$ & $\ldots \ldots \ldots$ & $\ldots \ldots \ldots$ \\
\hline $2 \mathrm{p} 3-10$ & $\ldots \ldots \ldots$ & $\ldots \ldots G \ldots$ & $\ldots \ldots \ldots$ & $\ldots \ldots \ldots$ & $\ldots \ldots \ldots$ \\
\hline p3-12 & $\ldots \ldots \ldots$ & $\ldots$..... & $\cdots \cdots \cdots$ & $\cdots \cdots \cdots$ & $\ldots \ldots$ \\
\hline p3-13 & $\ldots \ldots \ldots$ & $\ldots \ldots \ldots$ & $\ldots \ldots \ldots$ & $\ldots \ldots \ldots$ & $\ldots \ldots \ldots$ \\
\hline $2 \mathrm{~F} 8-1$ & $\ldots \ldots \ldots$ & $\ldots \ldots \ldots$ & $\ldots \ldots \ldots$ & $\ldots \ldots \ldots$ & ...G... \\
\hline $2 \mathrm{~F} 8-2$ & $\ldots \ldots \ldots$ & $\ldots \ldots \ldots$ & $\ldots G \ldots \ldots$ & $\ldots \ldots \ldots$ & $\ldots$..... \\
\hline $2 \mathrm{~F} 8-3$ & $\ldots \ldots \ldots$ & $\ldots \ldots \ldots$ & $\ldots G \ldots \ldots$ & $\ldots \ldots \ldots$ & ...G... \\
\hline $2 \mathrm{~F} 9-3$ & $\ldots \ldots \ldots$ & $\ldots \ldots \ldots$ & .G...... & $\ldots \ldots \ldots$ & $\ldots \ldots \ldots$ \\
\hline 2 F $9-4$ & $\ldots \ldots \ldots$ & $\ldots \ldots \ldots$ & $\ldots \ldots \ldots$ & $\ldots \ldots \ldots$ & $\ldots \ldots \ldots$ \\
\hline F10-1 & $\ldots \ldots \ldots$ & $\cdots \cdots \cdots$ & $\cdots \cdots \cdots$ & $\cdots \cdots \cdots$ & $\ldots \ldots \ldots$ \\
\hline F $10-2$ & $\ldots \ldots \ldots$ & $\ldots$..... & $\cdots \cdots \cdots$ & $\cdots \cdots \cdots$ & $\cdots \cdots \cdots$ \\
\hline $2 F 11-1$ & $\cdots \cdots \cdots$ & $\ldots \ldots \ldots$ & . G..... & $\cdots \cdots \cdots \cdots$ & $\cdots \cdots \cdots$ \\
\hline $2 \mathrm{~F} 11-2$ & $\cdots \ldots \ldots$ & $\cdots \ldots \ldots$ & $\cdots \ldots \ldots$ & $\cdots \cdots \cdots \cdots$ & $\cdots \cdots \cdots$ \\
\hline $2 \mathrm{~F} 11-3$ & $\cdots \cdots \cdots$ & $\cdots \cdots \cdots$ & .G..... & $\cdots \cdots \cdots \cdots$ & $\cdots \cdots \cdots$ \\
\hline $2 F 11-4$ & $\cdots \cdots \cdots$ & $\begin{array}{c}\cdots \cdots \cdots \\
\cdots \cdots \cdots\end{array}$ & $\begin{array}{l}\cdots G \ldots \ldots \\
\cdots \ldots \ldots\end{array}$ & $\begin{array}{l}\cdots \cdots \\
\ldots \ldots \ldots\end{array}$ & $\cdots \cdots$ \\
\hline $2 \mathrm{~F} 12-3$ & $\cdots \cdots \cdots$ & $\begin{array}{l}\cdots \cdots \\
\cdots \cdots\end{array}$ & $\begin{array}{c}\cdots \cdots \\
\cdots \cdots\end{array}$ & $\cdots \cdots \cdots$ & $\ldots \ldots \ldots$ \\
\hline $\begin{array}{l}2 \mathrm{~F} 13-2 \\
2 \mathrm{~F} 14-1\end{array}$ & $\cdots \cdots \cdots$ & $\cdots \cdots \cdots$ & $\begin{array}{l}\cdots \cdots \\
\cdots \cdots\end{array}$ & $\ldots \ldots \ldots$ & $\ldots \ldots$ \\
\hline $\begin{array}{l}2 \mathrm{~F}+4-1 \\
2 \mathrm{~F} 14-2\end{array}$ & $\cdots \cdots \cdots$ & $\ldots \ldots \ldots$ & $\ldots G \ldots \ldots$ & $\ldots \ldots \ldots$ & $\ldots \ldots \ldots$ \\
\hline $2 \mathrm{~F} 15-1$ & $\ldots \ldots \ldots$ & $\ldots \ldots \ldots$ & .G...... & $\ldots \ldots \ldots$ & $\ldots \ldots \ldots$ \\
\hline 2 F $15-2$ & $\ldots \ldots \ldots$ & $\ldots \ldots \ldots$ & $\ldots G \ldots \ldots$ & $\ldots \ldots \ldots$ & $\ldots \ldots \ldots$ \\
\hline 2 F15-3 & $\ldots \ldots \ldots$ & $\ldots \ldots \ldots$ & $\ldots G \ldots .$. & $\ldots$..... & $\ldots \ldots \ldots$ \\
\hline $2 F 15-4$ & $\ldots \ldots \ldots$ & $\ldots \ldots \ldots$ & $\ldots G \ldots . .$. & $\cdots \cdots \cdots$ & $\ldots \ldots \ldots$ \\
\hline $2 F 16-3$ & $\ldots \ldots \ldots$ & $\ldots \ldots \ldots$ & $\ldots \ldots \ldots$ & $\ldots \ldots \ldots$ & $\ldots \ldots \ldots$ \\
\hline $2 \mathrm{~F} 16-4$ & $\ldots \ldots \ldots$ & $\ldots \ldots \ldots$ & $\ldots \ldots \ldots$ & $\cdots \cdots \cdots$ & $\ldots \ldots \ldots$ \\
\hline $2 F 16-5$ & $\ldots \ldots \ldots \ldots$ & $\ldots \ldots \ldots$ & $\cdots \ldots \ldots$ & $\ldots \ldots \ldots$ & $\ldots \ldots \ldots$ \\
\hline $2 \mathrm{~F} 16-6$ & $\cdots \ldots \ldots$ & $\cdots \ldots \ldots$ & $\cdots \ldots \ldots$ & $\cdots \ldots \ldots$ & $\ldots \ldots \ldots$ \\
\hline 2 F $17-3$ & $\cdots \cdots \cdots$ & $\cdots \ldots \ldots$ & $\cdots \cdots \cdots$ & $\cdots \cdots \cdots$ & $\ldots \ldots \ldots$ \\
\hline 2F17-4 & $\cdots \cdots \cdots$ & $\cdots \cdots \cdots \cdots$ & $\cdots \cdots \cdots$ & $\cdots \cdots \cdots \cdots$ & $\cdots \cdots \cdots$ \\
\hline $2 F 17-5$ & $\cdots \cdots \cdots$ & & $\cdots \cdots \cdots \cdots$ & $\cdots \cdots \cdots \cdots$ & $\cdots \cdots \cdots$ \\
\hline $2 F 17-6$ & $\cdots \cdots \cdots$ & …G... & $\begin{array}{l}\cdots \cdots \cdots \\
\cdots \cdots\end{array}$ & $\cdots \cdots \cdots \cdots$ & $\cdots \cdots \cdots$ \\
\hline $\begin{array}{l}x 52626 \\
u 01132\end{array}$ & $\cdots \cdots \cdots$ & $\ldots$.... & $\ldots \ldots \ldots$ & $\begin{array}{lll}\cdots & \cdots & \cdots \\
------- & \end{array}$ & $\begin{array}{l}\cdots \\
-\end{array}$ \\
\hline U01131 & $\ldots \ldots \ldots$ & $\ldots \ldots \ldots$ & $\ldots \ldots \ldots_{--}^{-}$ & ---------- & --------- \\
\hline X03004 & $\ldots \ldots \ldots$ & $\ldots \ldots \ldots$ & $\ldots G \ldots \ldots--$ & ---------- & --------- \\
\hline a06496 & $\cdots \ldots \ldots$ & $\ldots \ldots \ldots$ & $\ldots G \ldots \ldots$ & $\ldots \ldots \ldots$ & $\ldots \ldots \ldots$ \\
\hline u01123 & $-------\ldots-$ & ---------- & ----------- & --------- & -------- \\
\hline U01128 & $-------\ldots-$ & --------- & ------------ & ---------- & --------- \\
\hline u01127 &.--------- & -------- & ------------ & ------------ & ---------- \\
\hline $\begin{array}{l}001126 \\
\times 02980\end{array}$ & $\ldots \ldots$ & $\ldots \ldots \ldots$ & . . . . . & 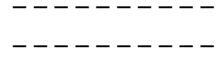 & 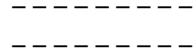 \\
\hline J01263 & & & $\ldots G \ldots \ldots$ & $\cdots \cdots \cdots \cdots$ & $\ldots \ldots \ldots$ \\
\hline u 01130 &..------- & ---------- & ---------- & ---------- & --------- \\
\hline 01129 &..------ & ---------- & --------- & ---------- & --------- \\
\hline 01121 & . C . C . & .A.G.G... & . C.....-- & --------- & ------- \\
\hline 01122 & . C... . . & .A.G.G... &.$C \ldots \ldots{ }^{--}$ & ---------- & --------- \\
\hline
\end{tabular}


Figura 7. Network de milho

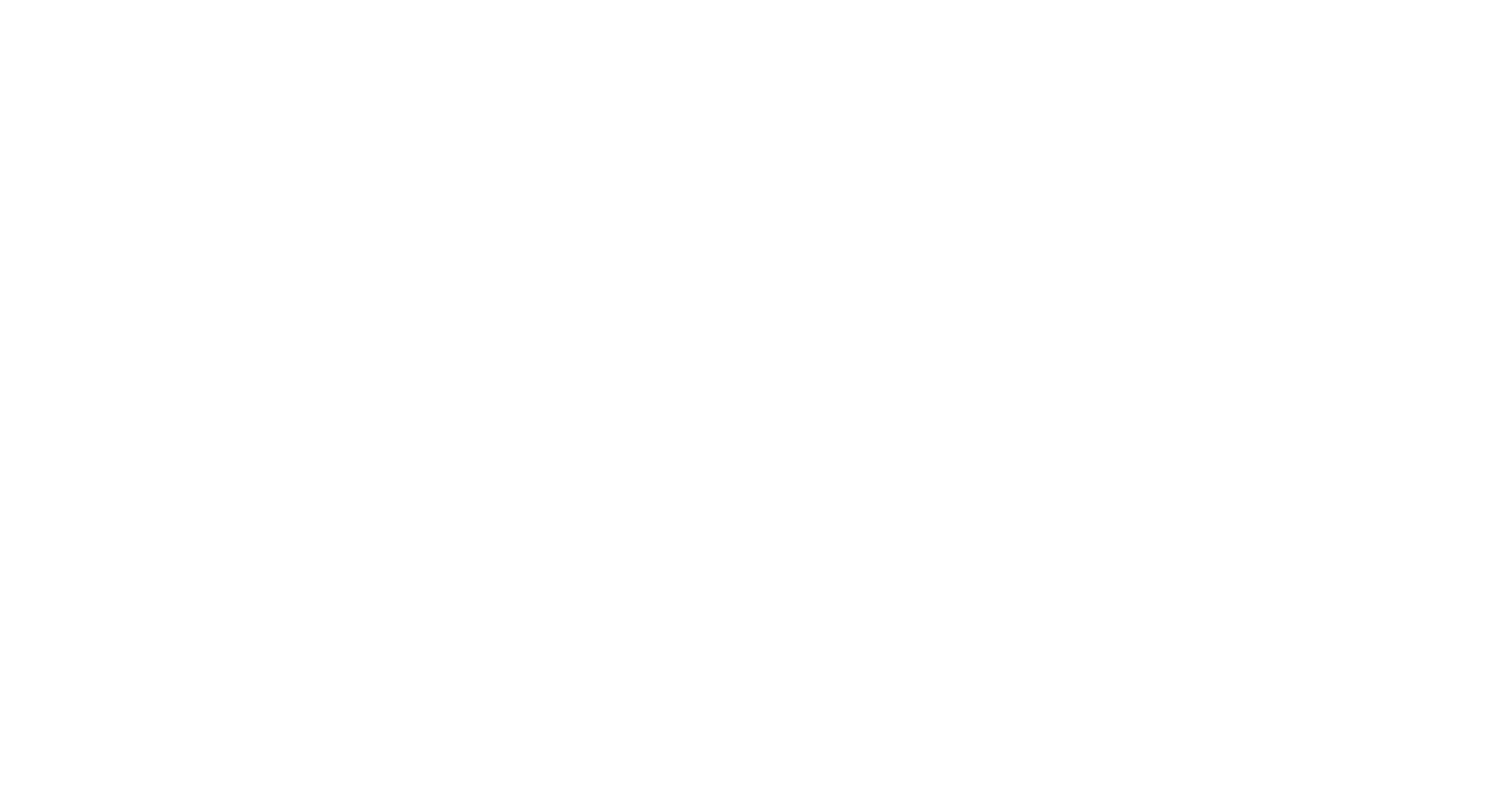




\subsection{Análise dos dados de MILHO}

Foram observadas diversas mutações/ diferenças na porção do gene Adh2, entre as distintas amostras estudadas. Cada uma destas sequiências distintas pode ser considerado um alelo, mostrando que existe um grau de diversidade nesta região deste gene, que está variando entre as diferentes espécies/ raças/ etnovariedades e amostras do material estudado.

Todas as semelhanças e diferenças das sequiências foram agrupadas na confecção do gráfico da "network" (figura 7), o qual nos ajuda a visualizar a relação entre os diferentes alelos encontrados nesta região do gene estudado. Este gráfico permite que possamos ter uma idéia de como deve ter sido a história evolutiva deste gene, mostrando-nos qual deve ter sido a sequiência (alelo) ancestral, como ele divergiu e quais as possíveis recombinações/ fluxo gênico, que podem ter ocorrido entre as diferentes raças e espécies parentais do milho ao longo do tempo, ou seja, quais as transformações/ mutações que ocorreram a partir da sequiência primitiva e que originaram os diferentes alelos encontrados nas amostras analisadas neste trabalho e na literatura.

Neste trabalho comparamos e analisamos as mutações ao longo de toda a região amplificada da fração do gene que amplificamos, mas demos maior destaque à uma pequena região do gene que possui um microsatélite. Esta região tem início na posição da base nitrogenada de número 39 (trinta e nove), no caso do alinhamento mostrado na figura 4. Em termos do gene Adh2, como um todo, ele se encontra por volta da posição 15 (menos quinze) até -10 (menos dez), segundo Goloubinoff et al (1993). Se faz interessante notar que este ultimo autor desconsiderou esta região de microsatélites em suas análises evolutivas do milho, alegando que é uma região sujeita a problemas durante a polimerização, no PCR. Entretanto, veremos que, ao contrário do que este último autor alega, esta região permitiu uma análise evolutiva interessante e oportuna para nossas amostras.

Microsatélites são repetições de seqüências genômicas simples, curtas, formadas por mono-, di-, tri- ou tetranucleotídeos repetidos em múltiplas cópias enfileiradas (em tandem) (Pena et al, 1989). No caso do ser humano, a classe mais abundante destes 
microsatélites é formado por dímeros $(\mathrm{CA})_{\mathrm{n}}$ e $(\mathrm{GT})_{\mathrm{n}}$, sendo encontradas mais de 50 mil cópias do dímero CA em nossos organismos, ainda segundo este ultimo autor. No caso do gene $A d h 2$, que analisamos no milho, esta região de microsatélite é uma repetição das bases nitrogenadas "GA", que se apresentavam repetidas de 3 a 14 vêzes, dependendo da amostra.

Microsatélites tendem a ter uma taxa de evolução (mutação) maior do que as outras regiões do gene, o que em nosso caso é vantajoso, já que estamos lidando com amostras de uma planta domesticada, cujo tempo de divergência evolutiva a partir das plantas selvagens ancestrais é muito recente e, portanto, ainda não houve, de modo geral, tempo para a ocorrência e acumulo de muitas mutações novas, que possam diferenciar as diferentes raças e sub-espécies deste grupo, principalmente quando estamos lidando com um fragmento genômico relativamente pequeno, como o que amplificamos (Allabi comunicação pessoal).

A diversidade de raças/ etnovariedades de plantas cultivadas em diferentes regiões, de modo geral, não é tanto devido ao acúmulo de novas mutações, mas sim resultada da ação da seleção diferenciada por cada populção humana de uma diversidade já pré-existente nos ancestrais selvagens destas espécies cultivadas. Deste modo, analisando uma região de microsatélite, cuja taxa de mutação é maior do que outras regiões do mesmo gene, a chance de que mutações diferenciáveis tenham surgido e se acumulado nas diferentes amostras é maior.

De fato, diversos alelos desta região de microsatélites foram encontrados (tabela 12 e 13). Estes alelos não variaram apenas no número de repetições do dímero GA, mas também pudemos notar a presença de dois tipos complexos deste microsatélite, denominados de tipo complexo $\mathrm{GA}_{n} \mathrm{TA}$ e tipo complexo $\mathrm{GA}_{1} \mathrm{AA}_{1} \mathrm{GA}_{\mathrm{n}}$. Estes dois complexos são aparentemente mutantes divergentes, que se diferenciaram a partir da seqüência simples do tipo $\mathrm{GA}_{\mathrm{n}}$. Deste modo, nós tínhamos dois componentes principais para a análise das amostras: o primeiro sendo o tipo de microsatélite encontrado (simples, ou dois tipos complexos) e o segundo componente sendo o tamanho do microsatélite, ou seja, o número de vezes que o dímero era repetido. 
Estas diferenças de tipo de microsatélites, entre simples e compostos, ficou ainda mais interessante quando plotamos geograficamente os dados, ou seja, visualizamos que tipo de microsatélite ocorria no local de origem da coleta das amostras.

Nas tabelas 12 e 13 e na figura 8, a seguir, mostramos um resumo dos tipos e tamanho dos microsatélites encontrados e apresentamos o mapa com todas as amostras utilizadas neste estudo, com sua localização geográfica e o tipo de microsatélite encontrado. Algumas observações e discussões sobre estes dados são apresentados em seguida.

Tabela 12. Resumo dos tipos de microsatélites encontrados nas amostras de milho, seu tamanho, sigla e nome da amostra, sua idade e número de clones obtidos de cada amostra (página seguinte). 


\begin{tabular}{|c|c|c|c|c|c|}
\hline Sigla & Variedade & Idade & Local & $\begin{array}{l}\mathrm{N}^{\circ} \text { de clones } \\
\text { obtidos }\end{array}$ & $\begin{array}{l}\text { Alelos de microsatélites } \\
\text { presente nas amostras }\end{array}$ \\
\hline E1 & Wuara & Moderno & Brasil- MT & 2 & $\mathrm{GA}_{3} \mathrm{TA}$ \\
\hline E5 & Moroti & Moderno & Brasil- PR & 2 & $\mathrm{GA}_{1} \mathrm{AA}_{1} \mathrm{GA}_{7}$ \\
\hline E6 & Cateto & Moderno & Brasil- MA & 3 & $\mathrm{GA}_{4} \mathrm{TA}$ \\
\hline E9 & Cristal & Moderno & Brasil- BA & 2 & $\mathrm{GA}_{4} \mathrm{TA} ; \mathrm{GA}_{1} \mathrm{AA}_{1} \mathrm{GA}_{7}$ \\
\hline E11 & Moroti-Guapi & Moderno & Paraguai & 5 & $\mathrm{GA}_{8}$ \\
\hline E12 & Guarani & Moderno & Brasil-SP & 2 & $\mathrm{GA}_{4} \mathrm{TA}$ \\
\hline E13 & Cristal & Moderno & Brasil- BA & 4 & $\mathrm{GA}_{1} \mathrm{AA}_{1} \mathrm{GA}_{6} ; \mathrm{GA}_{1} \mathrm{AA}_{1} \mathrm{GA}_{7}$ \\
\hline E14 & Caingang & Moderno & Brasil-SP & 6 & $\mathrm{GA}_{4} \mathrm{TA} ; \mathrm{GA}_{1} \mathrm{AA}_{1} \mathrm{GA}_{7}$ \\
\hline E15 & Cateto & Moderno & Brasil-BA & 6 & $\mathrm{GA}_{4} \mathrm{TA} ; \mathrm{GA}_{1} \mathrm{AA}_{1} \mathrm{GA}_{6}$ \\
\hline E21 & Cateto & Moderno & Brasil-SP & 5 & $\mathrm{GA}_{4} \mathrm{TA}$ \\
\hline E23 & Xavante & Moderno & Brasil-MT & 5 & $\mathrm{GA}_{4} \mathrm{TA}$ \\
\hline A2 & - & $570 \pm 60$ & Januária & 5 & $\mathrm{GA}_{1} \mathrm{AA}_{1} \mathrm{GA}_{7}$ \\
\hline A3 & - & $890 \pm 50$ & Januária & 5 & $\mathrm{GA}_{4} \mathrm{TA}$ \\
\hline A5 & - & $630 \pm 60$ & Januária & 6 & $\mathrm{GA}_{4} \mathrm{TA}$ \\
\hline A6 & - & $630 \pm 60$ & Januária & 5 & $\mathrm{GA}_{4} \mathrm{TA}$ \\
\hline A8 & - & $570 \pm 60$ & Januária & 4 & $\mathrm{GA}_{1} \mathrm{AA}_{1} \mathrm{GA}_{7}$ \\
\hline $\mathrm{A} 23$ & - & $940 \pm 60$ & Januária & 6 & $\mathrm{GA}_{4} \mathrm{TA}$ \\
\hline A34 & - & - & Januária & 5 & $\mathrm{GA}_{4} \mathrm{TA}$ \\
\hline G1 & Northern Flint & Moderno & Noroeste EUA & & $\mathrm{GA}_{13} ; \mathrm{GA}_{4} \mathrm{TA}$ \\
\hline GBF & Barkeley Fast & Moderno & Centro EUA & & $\mathrm{GA}_{1} \mathrm{AA}_{1} \mathrm{GA}_{6}$ \\
\hline G3 & Conflite Morocho & Moderno & Costa do Peru & & $\mathrm{GA}_{4} \mathrm{TA}$ \\
\hline G4 & Tabloncillo & Moderno & México Central & & $\mathrm{GA}_{4} \mathrm{TA}$ \\
\hline G5 & Kculli-47 & Moderno & Costa do Peru & & $\mathrm{GA}_{8}$ \\
\hline G6 & - & $440 \pm 40$ & Peru-Altas Montanhas & & $\mathrm{GA}_{9}$ \\
\hline G7 & - & $1500 \pm 50$ & Norte do Chile & & $\mathrm{GA}_{6} ; \mathrm{GA}_{4} \mathrm{TA}$ \\
\hline G8 & - & $4500 \pm 500$ & Costa do Peru & & $\mathrm{GA}_{8}$ \\
\hline G9 & Z.mays mexicana & Moderno & México - Terras Altas & & $\mathrm{GA}_{14} ; \mathrm{GA}_{9} \mathrm{TA}$ \\
\hline G10 & Z.mays parviglumis & Moderno & México-Terras Baixas & & $\mathrm{GA}_{6} ; \mathrm{GA}_{4} \mathrm{TA}$ \\
\hline G11 & Z.diploperenis & Moderno & México & & $\mathrm{GA}_{7} ; \mathrm{GA}_{9}$ \\
\hline G12 & Z.luxurians & Moderno & Guatemala & & $\mathrm{GA}_{7} ; \mathrm{GA}_{14}$ \\
\hline GTP & Tripsacun pilosun & Moderno & México & & $\mathrm{GA}_{6} \mathrm{AA}_{1} \mathrm{CA}_{1}$ \\
\hline$\overline{D B F}$ & Barkeley Flint & Moderno & EUA & & $\mathrm{GA}_{1} \mathrm{AA}_{1} \mathrm{GA}_{7}$ \\
\hline
\end{tabular}


Tabela 13. Resumo dos tipos de microsatélites encontrados nas amostras.

\begin{tabular}{lll}
\hline $\mathrm{n} *$ & $\mathrm{GA}$ & $\mathrm{GA}_{\mathrm{n}} \mathrm{TA}$ \\
\hline 14 & $\begin{array}{l}\text { Z.mays mexicana- } \mathrm{G} 9 \\
\text { Z.luxurians- G12 }\end{array}$ \\
13 & $\begin{array}{l}\text { EUA- moderno-G1 } \\
\end{array}$ \\
9 & $\begin{array}{l}\text { Peru-arqueológico- G6 } \\
\text { Z.diploperenis- G11 }\end{array}$ & Z.mays mexicana-G9 \\
8 & $\begin{array}{l}\text { Paraguai - moderno-E11 } \\
\text { Peru- moderno-G5 } \\
\text { Peru-arqueológico-G8 }\end{array}$ \\
7 & $\begin{array}{l}\text { Z.diploperenis-G11 } \\
\text { Z.luxurians- G12 }\end{array}$
\end{tabular}

$6 \quad$ Chille-arqueológico-G7 Z.mays parviglumis- $\mathrm{G} 10$

4

3

$\mathrm{n} * \mathrm{GA} \quad \mathrm{GA}_{\mathrm{n}} \mathrm{TA}$

* número de vezes que o dímero GA é repetido.
Brasil- moderno-E5;E9; E13, E14 Brasil- arqueológico- A2; A8. EUA-moderno- DBF

Brasil- moderno-E13; E15. EUA- moderno-GBF
Brasil- moderno - E6; E9; E12;

E14; E15; E21; E23.

Brasil - arqueológico- A3; A5;

A6; A23; A34.

EUA- moderno- G1

México - moderno-G4

Peru-moderno- G3

Chile- arqueológico-G7

Z.mays parviglumis-G10

Brasil- moderno-E3
$\mathrm{GA}_{1} \mathrm{AA}_{1} \mathrm{GA}_{\mathrm{n}}$ 
Figura 8. Mapa com a localização dos microsatélites de milho.

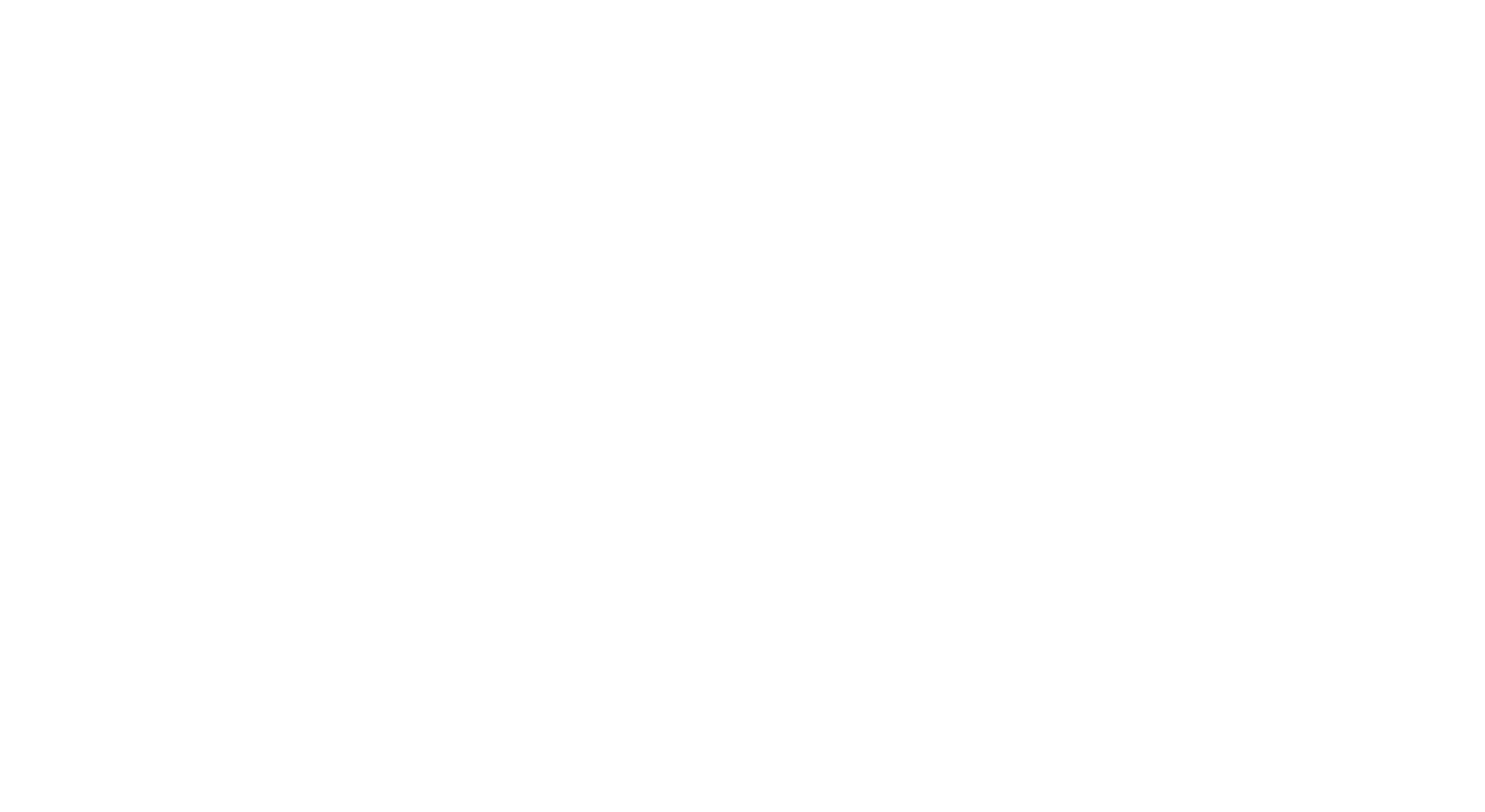




\subsection{Discussão sobre os dados de milho}

Como dissemos acima, esta discussão se baseia principalmente na análise dos dados obtidos a partir da região de microsatélite das amostras, mas tendo em mente que as outras partes da região do gene amplificadas também foram usadas em considerações mais específicas.

Com bases em dados geográficos, dos tipos de microsatélites e de dados de trabalhos de literatura, como o da Dra Piperno (1978), Dra McClintock et al (1984) e Goloubinoff et al(1993), os quais discutem a origem, difusão e colonização das diferentes raças de milho nas três Américas desde a sua domesticação, procuramos entender como foi a história da dinâmica evolutiva do milho.

O tipo simples $-\mathrm{GA}_{n}$ - deve ser o tipo mais primitivo, o ancestral, tendo os tipos complexos se originado por mutação a partir dele. No trabalho, o tipo simples GA, varia de tamanho entre 6 e 14 repetições deste dímero, dependendo da amostra. Microsatélites podem aumentar ou diminuir de tamanho com relativa facilidade, pois no pareamento entre os cromossomos homólogos, pode haver um pareamento deslocado, onde a segunda repetição GA pode se parear com a quarta, por exemplo e, ao ocorrer um crossing-over entre os cromossomos homólogos, ocorre um aumento do tamanho do microsatélite em um dos homólogos, enquanto no outro ocorre um encurtamento (Allabi - comunicação pessoal) ${ }^{2}$.

Já no caso dos tipos complexos, este pareamento se faz mais preciso, pois a sequência é mais específica e portanto a parte complexa do microsatélite tende a ser menos sujeita a variação do que a parte simples, do restante do microsatélite. Deste modo, uma mutação de ponto que ocorra em uma base de um microsatélite de tipo simples tende a criar um alelo de microsatélite de tipo complexo, o qual tenderá a variar menos do que o tipo simples.

Deste modo, levantando os tipos e tamanhos dos microsatélites em uma dada região geográfica e no tempo (através das amostras arqueológicas), é possível recriar

\footnotetext{
2 Allabi, R (UMIST- Manchester) Comunicação pessoal, 1999.
} 
quais eram os alelos que existiam nas primeiras raças de milho que colonizaram as Américas e como eles foram variando com o tempo e nos locais em que foi disseminado.

Começaremos a discussão separadamente, pelo tipo de microsatélite encontrados e sua distribuição geográfica (Observe a tabela 12 e 13, para melhores detalhes).

Nas amostras oriundas da região de origem de domesticação do milho (México e Guatemala), os tipos de microsatélite encontrados nas amostras de milho - em Z.mays mays; nas subespécies - Z.mays mexicana e Z.mays parviglumis; nas amostras das outras espécies do gênero - Z.diploperennis e Z.luxurians; e em uma outra espécie relacionada ao milho, Tripsacun pilosum, foi encontrado o tipo primitivo $\mathrm{GA}_{\mathrm{n}}\left(\mathrm{GA}_{6} ; \mathrm{GA}_{7} ; \mathrm{GA}_{9}\right.$ e $\mathrm{GA}_{14}$ ), além do tipo complexo $\mathrm{GA}_{\mathrm{n}} \mathrm{TA}\left(\mathrm{GA}_{4} \mathrm{TA}\right.$ e $\left.\mathrm{GA}_{9} \mathrm{TA}\right)$, não aparecendo em nenhuma destas amostras estudadas o tipo complexo $\mathrm{GA}_{1} \mathrm{AA}_{1} \mathrm{GA}_{\mathrm{n}}$, sendo ainda que na amostra do Tripsacun pilosum foi encontrado um tipo complexo exclusivo para esta espécie - $\mathrm{GA}_{6} \mathrm{AA}_{1} \mathrm{CA}_{1}$ - mas que se assemelha em muito com os tipos encontrados dentro do gênero Zea, principalmente em relação ao dímero-base do microsatélite e à posição que este ocupa no gene, comprovando a relação filogenética entre estas espécies.

$\mathrm{Na}$ região dos Estados Unidos os três tipos estão presentes, tanto o simples $\left(\mathrm{GA}_{13}\right)$ como os dois complexos $\left(\mathrm{GA}_{4} \mathrm{TA} ; \mathrm{GA}_{1} \mathrm{AA}_{1} \mathrm{GA}_{6}\right.$ e $\left.\mathrm{GA}_{1} \mathrm{AA}_{1} \mathrm{GA}_{7}\right)$.

Em relação à América do Sul, um padrão geográfico aparentemente se faz presente, onde, de modo geral, o tipo simples de microsatélite - $\mathrm{GA}_{\mathrm{n}}\left(\mathrm{GA}_{6} ; \mathrm{GA}_{8}\right.$ e $\left.\mathrm{GA}_{9}\right)$ está presente quase que exclusivamente nas regiões Andinas, na parte oeste do continente, enquanto os dois tipos complexos $\left(\mathrm{GA}_{3} \mathrm{TA}, \mathrm{GA}_{4} \mathrm{TA}, \mathrm{GA}_{1} \mathrm{AA}_{1} \mathrm{GA}_{6} \mathrm{e}\right.$ $\mathrm{GA}_{1} \mathrm{AA}_{1} \mathrm{GA}_{7}$ ) aparecem principalmente na região das terras baixas, na parte central e leste do continente. $\mathrm{O}$ tipo complexo $\mathrm{GA}_{1} \mathrm{AA}_{1} \mathrm{GA}_{\mathrm{n}}$ aparece ainda mais restrito a parte leste do continente, ao longo das bacias hidrográficas do rio São Francisco e rio ParanáParaguai. As exceções a este padrão Terras Altas/ Terras Baixas está melhor discutido a frente.

Esta distinção biogeográfica entre os microsatélites simples e os complexos na América do Sul é também vista nas amostras arqueológicas, onde as duas amostras arqueológicas do Peru possuem apenas a estrutura simples $\mathrm{GA}_{8}$ e $\mathrm{GA}_{9}$ (Goloubinoff et 
al, 1993), enquanto as amostras de Januária apresentam somente os dois complexos, sem haver a ocorrência do tipo simples. Exceção para este fato é a amostra arqueológica do Chile, a qual apresenta o tipo simples, $\mathrm{GA}_{6}$, além do tipo complexo $\mathrm{GA}_{4} \mathrm{TA}$. Este fato será melhor discutido à frente. Aparentemente, parece ser o caso de que a distribuição atual das estruturas dos microsatélites pela América do Sul é mais um resultado de um fenômeno antigo do que moderno, como sugere este último autor.

A nossa interpretação para explicar esta distinção de distribuição de tipos de microsatélites na América do Sul é de que diferentes raças de milho, contendo distintos alelos deste gene, devem ter colonizado a América do Sul, independentemente, com cada tipo entrando em diferentes momentos históricos e colonizando diferentes áreas.

Esta idéia é compartilhada pelos trabalhos de Piperno (1978) e McClintock et al (1984). A primeira pesquisadora trabalhou com amostras arqueológicas de fitólitos de milho, na região do Panamá, enquanto, no segundo trabalho, os pesquisadores trabalharam analisando citologicamente a presença de Knobs nos cromossomos das diversas amostras modernas e etnovariedades por eles estudadas, das três Américas.

Fitólitos são microestruturas minerais que se formam naturalmente dentro de tecidos vegetais e que resistem melhor ao intemperismo, podendo ser preservados no solo. Sua forma é específica para cada espécie e, deste modo, ele pode ser usado como testemunha da ocorrência de determinada espécie no local.

Deste modo, Piperno afirma que o milho estava presente no Panamá desde antes da fase ceramista daquela região, com vestígios de sua presença nos horizontes cronológicos entre 5.000 - 2.800 A.C.. É interessante notar que as amostras pertencentes a este primeiro período se encontram todas nas regiões de altas altitudes do Panamá, enquanto as amostras que se encontram nas regiões das terras baixas do Panamá, ao longo dos grandes rios, só aparecem a partir do ano 1.000 A.C.

Portanto, esta mesma autora sugere que por volta de 1.000 A.C., houve uma dramática mudança de orientação na cultura de subsistência, habitação e utensílios na região das terras baixas do Panamá, indicando que as populações daquela área sofreram uma dramática mudança cultural, inclusive com a introdução de novos alimentos, como o milho. 
Gostaríamos de ressaltar três pontos neste momento. O primeiro é que o milho é uma planta altamente dependente do homem e sua difusão através das Américas só pôde ser feita com a ação direta do homem, transportando-a (Martins- comunicação pessoal) ${ }^{3}$. O segundo ponto é que os vestígios encontrados das populações que viviam nas regiões das terras altas e baixas do Panamá são bastante distintos, cada um tendo características próprias, o que deve ser consequiência da adaptação das culturas humanas a dois tipos tão distintos de ambientes, os quais necessitam de tecnologías específicas para sobreviverem em cada uma das regiões. Por exemplo, enquanto as populações que moravam ao longos dos rios utilizavam canoas como meio de transporte, as populações das terras altas se locomoviam preferencialmente a pé e utilizaram, a partir de um dado momento, animais para transporte.

Esta diferença cultural deve ter sido preponderante na escolha de qual caminho seguir quando estas populações chegaram no norte da América do Sul, encontrando desde regiões de altas montanhas (Andes), até grandes cursos fluviais através da floresta tropical, optando provavelmente a seguir por ambientes aos quais estavam mais adaptados, no caso do milho ter sido introduzido através de migrações humanas, ou ainda, no caso do milho ter entrado na América do Sul através de trocas, estas devem ter ocorrido entre populações humanas com certo grau de similaridade cultural (como por exemplo em relação ao tipo de ambiente que habitavam).

O terceiro ponto é que o milho foi domesticado em regiões de altitudes no sul do México e, portanto, as primeiras plantas/ etnovariedades não apenas estavam adaptadas a um ambiente de altitude, como também estavam ligadas a populações que tinham uma cultura desenvolvida em regiões montanhosas, o que deve ter contribuído para que sua difusão inicial se desse através de ambientes semelhantes, levado por culturas humanas também parecidas e, só após uma adaptação do milho a regiões de menor altitude, é que este pôde começar a colonizar e ser usado por populações com culturas ligadas às regiões de terras baixas.

\footnotetext{
${ }^{3}$ Martins, P.S. (ESALQ-USP) Comunicação pessoal, 1996.
} 


\subsubsection{Expansão do milho para a América do Sul}

As amostras de milho mais antigas na América do Sul, estudadas neste trabalho, são do Peru, de 4.500 anos atrás, (Goloubinoff et al, 1993) e elas aparentemente não contem complexos de microsatélites, sugerindo que os primeiros acessos de milho que entraram na América do Sul continham apenas o tipo simples $\mathrm{GA}_{\mathrm{n}}$. Somente em uma amostra moderna desta região é que aparece um dos tipos complexos, o tipo $\mathrm{GA}_{\mathrm{n}} \mathrm{TA}$, sendo que o outro tipo complexo não aparece em nenhuma amostra da região da Cordilheira dos Andes. Isto sugere que o conjunto genético das raças de milho da América Central, somente continham o tipo simples quando a expansão (migração) para a região oeste da América do Sul ocorreu e aparentemente esta região não recebeu amostras de raças de milho contento microsatélites de tipos complexos até mais recentemente.

A mais antiga evidência de ocorrência dos tipos complexos de microsatélites vem da amostra de 1500 anos do Chile (Goloubinoff et al, 1993), seguida pela de Januária com 1.000 anos de idade, nas quais a estrutura $\mathrm{GA}_{4} \mathrm{TA}$ ocorre. Esta estrutura também está presente em raças de teosinte encontradas no México, sugerindo que este complexo pode ter surgido por mutação no teosinte e, por recombinação entre populações desta planta e de milho, ter passado (fluxo gênico) para o milho antes que uma segunda leva migratória de raças para o continente sul americano ocorresse.

Aparentemente, esta segunda leva contendo este tipo complexo seguiu um caminho diferente em relação às primeiras raças que chegaram no Peru, provavelmente através de rotas fluviais pelo interior do Brasil, como demonstram as amostras arqueológicas e modernas de raças das terras baixas.

Gostaríamos de chamar a atenção novamente para o trabalho de Piperno (1978), onde ela descreve duas expansões de milho através do Panamá, em dois momentos históricos distintos (5.000 - 7.000 anos atrás [BP] e por volta de 3.000 anos atrás [BP]) e por duas rotas distintas (pelas terras altas e pelos rios das terras baixas, respectivamente). Estes dados se encaixam de forma oportuna aos dados genéticos levantados em nosso trabalho, sugerindo que as primeiras raças que cruzaram o Panamá 
deviam conter alelos do tipo simples de microsatélite $\left(\mathrm{GA}_{n}\right)$, enquanto a segunda leva deve ter cruzado o Panamá carregando raças com os dois complexos $\left(\mathrm{GA}_{n} \mathrm{TA}\right.$ e $\left.\mathrm{GA}_{1} \mathrm{AA}_{1} \mathrm{GA}_{\mathrm{n}}\right)$.

Além disto, as raças destas duas levas distintas aparentemente não entraram em contato, como demonstra a não existência do tipo simples $\mathrm{GA}_{\mathrm{n}}$ tanto em amostras modernas como arqueológicas do Brasil, além da escassa ocorrência dos tipos complexos em amostras dos Andes atuais e arqueológicas.

Exceção deste fato são as duas amostras do sul do continente, onde a amostra do Chile de 1500 anos de idade possui o tipo complexo GA4T e o tipo simples GA, enquanto a etnovariedade de milho Moroti-guapi (pertencente a tribo Guaraní), do Paraguai, possui somente o tipo simples - $\mathrm{GA}_{8}$. Encontramos ainda o tipo complexo $\mathrm{GA}_{4} \mathrm{TA}$ em uma amostra moderna no Peru. Estes dados podem ser considerados como evidências de fluxo gênico na região sul do continente.

Este fluxo gênico pode ser explicado pela presença de contatos entre populações pré-históricas da região sul da América do Sul, o qual pode ter permitido a troca ou aquisição de diversos bens culturais e mercadorias, como amostras/ raças de milho, como já aventado por muitos estudiosos (Brieger, 1958, Steward, 1963; McClintock et al, 1984; Bird et al,1991; Neves, 1997), mostrando que deveria ocorrer um contato entre as populações habitantes das regiões abaixo do Trópico de Capricórnio, desde a costa oeste chilena, até a região leste da América do Sul.

Por exemplo, no trabalho de Neves et al (1997), os autores elaboram conclusões sobre levas de povoamento humano na América do Sul baseados em estudos morfológicos de crânios humanos encontrados em diversos sítios arqueológicos espalhados pelo continente sul-americano, com amostras com idades que variam desde 12.000 anos até com algumas sendo do século passado.

Mesmo acreditando que seria necessário uma ampliação do número de amostras deste ultimo trabalho para que pudéssemos utilizá-lo mais especificamente no que queremos mostrar, é interessante notar que os autores reunem em um grupo isolado as populações de agricultores chilenos com o grupo de agricultores da costa sudeste brasileira, com ambos os grupos tendo idades atadas de 1.000 anos atrás (BP), indicando 
a correlação entre ambos, correlação esta maior até do que a encontrada entre os agricultores da costa sudoeste e com outros grupos estudados na costa Brasileira, com outras idades e culturas.

Outro trabalho que apresenta fortes evidências de contato e trocas de mercadorias entre estas populações do sul é o de Steward (1963). Apenas citando algumas destas evidências apresentadas pelo autor:

- Ele fala que mesmo havendo um grande contraste entre os ambientes da costa desértica chilena e suas altas montanhas, historicamente, as populações das duas áreas eram culturalmente uma só unidade, principalmente durante o período dominado pelas culturas Diaguita, Atacameno e Araucanian, que se estendem desde aproximadamente o ano e $500 \mathrm{AD}$, e que dominaram culturalmente vastas porções do centro e norte do Chile e noroeste da Argentina, sendo que possuem também vestígios de contato e influência a partir da região do Chaco e Centro-Sul do Brasil.

- A região da unidade cultural do Chaco, que corresponde à parte centro norte da Argentina, sul do Mato Grosso do Sul e parte do Paraguai é caracterizada por ter tido uma influencia grande, tanto da região Sul dos Andes, como da região Central e Sul do Brasil e Paraguai, principalmente, no caso destas últimas regiões, a partir das áreas ao longo das margens do rio Paraná e Paraguai.

- Alguns rios cortam a região do Chaco desde o Noroeste da Argentina até o sudeste desta, como os rios Salado e Dulce, os quais foram usados como rotas de contatos e trocas de mercadorias, como demonstram muitos achados da área.

- A região sudeste desta região faz fronteira com a região dominada culturalmente pelos Guaranis no passado e, acredita-se que muito da cultura deste povo tenha chegado a região dos Andes do Sul por esta rota, como cerâmicas, urnas funerárias, entre outros, assim como este povo também adquiriu muito material dos Andes, principalmente de metalurgia.

- A presença de conchas marinhas de espécies do Oceano Atlântico no Chile e de conchas típicas do Oceano Pacífico no Argentina e Paraguai, junto com utensílhos usados pelos indígenas da época, demostram não apenas o costume de usar este tipo 
de material em confecções e trabalhos, mas principalmente que eles intercambiavam materiais de locais muito distantes.

- Um último exemplo deste contato pode ser demostrado durante o período inicial de colonização espanhola e portuguesa na América do Sul, quando estes exploradores pretendiam chegar às minas de ouro e prata peruanas a partir da foz do Rio da Prata, no Atlântico e, para isto, utilizaram como guias em suas expedições índios que habitavam a costa leste do continente (Bueno, 1998).

Portanto, estas evidências demonstram que as diferentes populações que habitavam a região sul da América do Sul mantinham relativo contato (seja amigável ou não), permitindo uma difusão cultural e material entre diferentes áreas, criando uma ponte que permitiu um fluxo genético entre as terras baixas e os Andes do Sul, fato este também demonstrado no trabalho de McClintock et al (1984), os quais encontraram em alguns materiais analisados, raças de milho chileno com padrões citológicos muito mais correlacionadas com raças brasileiras do que com aquelas dos Andes centrais e do norte.

Deste modo, acreditamos que a presença do microsatélite do tipo complexo $\mathrm{GA}_{\mathrm{n}} \mathrm{TA}$ em uma amostra arqueológica do Chile se deva à existência deste "comércio" Leste-Oeste-Leste, na parte sul do continente, o qual possibilitou a introdução deste alelo na região andina, vindo da região das terras baixas. Ainda, a existência deste tipo complexo em uma amostra moderna no Peru pode ser explicada de duas maneiras: $\mathrm{Ou}$ este alelo foi introduzido via Chile, em tempos remotos, ou é uma variedade recém introduzida, pela influência dos colonizadores europeus.

Para colaborar com nossa hipótese de que o tipo complexo $\mathrm{GA}_{\mathrm{n}} \mathrm{TA}$ encontrado na amostra arqueológica do Chile deve ter vindo da região das terras baixas do nosso continente e não via Andes, devemos observar as outras mutações que ocorrem ao longo do fragmento genético que amplificamos e que estão organizados no gráfico de network (figura 7).

No gráfico apresentamos todas as amostras estudadas e as mutações (definidas pelo número da posição que elas ocorrem no alinhamento - figura 4) presentes em cada uma das amostras. Deste modo, pode-se ver o quanto uma amostra difere da outra e 
quais foram as mutações que ocorreram entre as sequiências que estamos analisando, ao longo da história evolutiva das diferentes amostras.

Pelo gráfico, onde utilizamos na base da "árvore" a espécie T. pilosum, para que pudéssemos ter uma melhor visão da história da divergência evolutiva que originou o milho e seus parentes selvagens, observamos que os alelos das amostras que possuem o tipo simples $\mathrm{GA}_{\mathrm{n}}$ tendem a ficar mais distribuídos nos ramos inferiores e centrais da "árvore" do gráfico, enquanto os alelos com o complexo $\mathrm{GA}_{\mathrm{n}} \mathrm{TA}$ tendem a ficar na parte superior esquerda, enquanto os alelos contendo o tipo complexo GAAAGA $_{n}$ tendem a ficar no ramo direito da figura.

Podemos ainda observar as mutações que foram geradas e acumuladas pelo tempo e que separam os diferentes alelos, que são identificadas pelos números presentes ao longo das linhas que separam as amostras, e que significam a posição do nucleotídeo no fragmento do gene amplificado.

Esta característica de arquitetura de gráfico de network, onde a partir de um ponto as amostras se irradiam, normalmente é característico de populações sob ritmo intenso de expansão e evolução (Bandelt et al, 1995), o que é de se esperar que aconteça quando populações de plantas domesticadas estão sendo levadas a novas regiões, se espalhando e sujeitas a novas pressões de evolução, tanto devido aos fatores naturais do novo ambiente, como devido a pressão evolutiva exercida pelo homem, o qual em parte dirige, manipula o sentido de evolução que estas plantas sob seu domínio irão seguir.

Pelo gráfico vemos bem claramente que os dois tipos complexos seguem caminhos evolutivos relativamente distintos, ou seja, sem sofrerem recombinação, com poucas amostras fugindo desta "regra". E são exatamente dois dos alelos da amostra arqueológica chilena que fogem a esta regra (G7-A e G7-B).

Estes dois alelos da amostra chilena possuem o tipo complexo de microsatélite $\mathrm{GA}_{\mathrm{n}} \mathrm{TA}$. Entretanto, a maior parte das outras mutações presentes no resto da seqüência destes dois alelos são característicos do tipo GAAAGA $_{n}$ (mutações nas posições 151; 153 e 155, para a amostra G7-B e mutações $132 ; 151 ; 153 ; 155 ; 169 ; 179$ e 182 , para a amostra G7-A). Deste modo, podemos afirmar que estes dois alelos foram originados 
por eventos de recombinação entre raças de genótipos com alelos do tipo GAAAGA recombinados com genótipos com alelos $\mathrm{GA}_{\mathrm{n}} \mathrm{TA}$.

Como encontramos o tipo GAAAGA $n$ na América do Sul exclusivamente nas regiões das terras baixas e mais próximas a costa atlântica, podemos concluir que a presença de sítios de mutação típicas deste complexo em alelos arqueológicos do Chile, só pode ser explicado por eventos de recombinação ocorridos nas regiões das terras baixas, antes destes alelos recombinantes terem sido "levados" ao Chile.

Em resumo, acreditamos que distintas raças de milho, contendo alelos particulares, foram pré-historicamente introduzidas na América do Sul, sendo que as primeiras raças colonizaram a região das terras altas do continente e, posteriormente, uma segunda leva, com raças distintas da primeira, colonizaram a região das terras baixas.

Acreditamos ainda que, em termos do milho, a influencia dos Andes em relação as terras baixas do continente Sul Americano foi menor do que se costuma acreditar, pois caso o padrão de raça de milho encontrado no Peru, o qual pertence a uma leva migratória anterior a leva com o padrão de Januária, tivesse sido difundido mais amplamente pela América do Sul, devido a uma possível influência da cultura dos Andes Central, é de se esperar que este padrão fosse encontrado pelo menos nas raças coletadas nas comunidades indígenas e de pequenos agricultores atuais, o que não ocorre, sugerindo que em nenhum momento da história este complexo genômico atingiu a região centro-leste da América do Sul, ou se chegou, foi de forma restrita e se diluiu em relação aos alelos complexos.

Por outro lado, podemos ver que a influência das terras baixas se faz presente na região dos Andes do Sul, no Chile, mostrando que as barreiras geográficas e ambientais existentes entre o norte do Chile e o centro sul do Brasil foram suplantadas pelas relações e contatos culturais, permitindo que regiões geográficas tão distantes, como norte do Chile e Januária, estivessem tão próximas geneticamente.

Sugerimos ainda que este padrão de tipos de milho - terras altas/ terras baixas, que primeiro surgiu devido a características de migração, difusão e/ ou contato das populações humanas que introduziram aqui o milho, foi praticamente mantido intacto 
até os dias atuais devido a particularidade histórica de colonização européia nos últimos 500 anos de nossa história, onde as regiões das terras baixas foram colonizadas pelos portugueses e as terras altas pelos espanhóis, mantendo qualquer barreira cultural que por ventura já existisse, dificultando assim maiores trocas e contatos entre mercadorias entre ambas as regiões, fato este que só mais recentemente começa a ser quebrado, com políticas de acordo de cooperação entre os países destes dois blocos.

Gostaríamos agora de ressaltar mais dois pontos sobre a história evolutiva e difusão do milho, que os dados fornecem.

A primeira é em relação ao tipo complexo GAAAGA . Observando as tabelas e mapas de onde ele ocorre e em quais amostras, vemos primeiramente que este tipo não ocorre em nenhuma amostra de milho ou parentais desta espécie na região do México.

Este fato pode ser devido a uma sub-amostragem das amostras daquela região, ou pode ser porque este complexo surgiu historicamente em uma outra região geográfica e não foi introduzido no México até mais recentemente. A hipótese da sub-amostragem é plausível, visto que a amostra G10-A, originária das regiões de terras baixas do México, tem a mesma característica da amostra arqueológica G7-A, do Chile, que, mesmo tendo o microsatélite complexo tipo $\mathrm{GA}_{\mathrm{n}} \mathrm{TA}$, possui uma série de mutações típicas do tipo GAAAGA $_{\mathrm{n}}$. Ligado a isto, esta amostra G10 é a subespécie Zea mays parviglumis, a qual é um dos prováveis parentais do milho. Além disto, como sublinhamos acima, a amostra G10 é adaptada a regiões de Terras Baixas, exatamente onde o complexo GAAAGA $_{n}$ esta difundido na América do Sul.

Vemos ainda que, em termos de América do Sul, ele está restrito ao Brasil e, mais particularmente as bacias hidrográficas do São Francisco e Paraná-Paraguai, ou seja, ele ocorre mais na parte leste do continente, não sendo difundido na parte central, como ocorre com o outro complexo (GA $\mathrm{TA})$.

Ainda, em relação ao material arqueológico, enquanto o tipo complexo $\mathrm{GA}_{n} \mathrm{TA}$ está presente em diferentes amostras de Januária, desde mais ou menos 1000 até 600 anos atrás $[\mathrm{BP}]$ e ocorre nas três cavernas estudadas, o tipo $\mathrm{GAAAGA}_{\mathrm{n}}$ só aparece por volta de 600 anos atrás [BP] e em uma caverna apenas (Lapa do Boquete). 
Estes dados podem estar sugerindo que: Primeiro, o tipo GAAAGA $A_{n}$ pode ter se originado fora da região do México, talvez, inclusive, em terras brasileiras. Segundo, este alelo pode ter sido introduzido posteriormente, em relação ao alelo $\mathrm{GA}_{n} \mathrm{TA}$, fato este baseado nos registros arqueológicos e de distribuição geográfica mais restrita.

Isto pode estar sugerindo que um novo alelo deste gene do milho foi introduzido e difundido na parte leste do Brasil, talvez em uma terceira migração/ introdução de raças de milho na América do Sul. Por ele ter ficado restrito somente na região destas duas bacias hidrográficas, é de se aventar que este material deve ter sido disseminado através de uma cultura humana que se fazia mais ou menos presente nesta região em que hoje encontramos estes alelos e que a difusão se deu preferencialmente por deslocamentos/ contatos, através de navegações fluviais. Este dado pode ajudar em análises de influência cultural de populações indígenas do passado.

McClintock et al (1984) dizem que amostras de raças de milho da costa leste do Brasil, entre elas a raça Cateto, são muito correlacionados com raças de milho das Antilhas e que provavelmente esta última região deve ter fornecido algumas raças de milho em algum momento do passado à parte leste do nosso País. A autora diz que esta influência das Antilhas é mais recente, mas sem indicar uma data mais precisa para isto, por falta de amostras arqueológicas.

A ocorrência deste complexo GAAAGA $\mathrm{n}_{\mathrm{n}}$ em uma amostra de 600 anos de idade na região do Médio São Francisco (Januária), pode estar indicando o momento histórico em que a influência de uma nova amostra de raças de milho ou até mesmo uma nova cultura indígena teve início e se fez mais presente na costa leste do Brasil. Se assim for, Januária pode ter recebido primeiramente (há pelo menos 1000 anos atrás), raças de milho com alelos do tipo $\mathrm{GA}_{\mathrm{n}} \mathrm{TA}$ e, posteriormente, ter recebido raças com novos alelos, com o tipo $\mathrm{GAAAGA}_{\mathrm{n}}$. Isto pode ter ocorrido através de introduções por uma mesma linhagem cultural indígena, através de uma mesma rota ou por distintas linhagens indígenas, podendo ser até mesmo por caminhos de introdução diferentes. Somente com uma ampliação este estudo é que poderemos ter uma maior certeza deste fato.

O complexo GAAAGA $A_{n}$ também se faz presente em amostras modernas dos EUA. Somente com estas amostras modernas dos EUA, sendo algumas delas variedades 
comerciais, portanto com certo grau de melhoramento genético direcionado por programas de melhoramento, os quais podem ter utilizado genótipos de diferentes fontes, não podemos saber se isto se trata de uma introdução recente ou antiga, inclusive podendo ser das Antilhas também (?), caso este complexo tenha realmente surgido nestas ilhas.

Esta hipótese deve ser melhor estudada, principalmente através de uma análise genética em etnovariedades de milho das Antilhas, mas o fato deste complexo estar mais confinado a uma porção do Brasil e que pode ser o reflexo do limite de influência de um grupo cultural indígena, chama a atenção.

Um último ponto sobre a história do milho que gostaríamos de comentar diz respeito à própria origem desta planta cultivada. Existe uma discussão na literatura de qual teria sido a subespécie parental do milho, se foi a subespécie Z. mays mexicana ou a Z. mays parviglumis.

Características morfológicas apontam para a primeira subspécie como sendo o ancestral, enquanto análises de isoenzimas apontaram para a segunda (Doebley, 1990). Não pretendemos nos aprofundar nesta discussão, mas se faz interessante notar que enquanto a subspécie Z. mays parviglumis possue o microsatélite do tipo complexo $\mathrm{GA}_{4} \mathrm{TA}$, o qual esta presente em muitas amostras de milho estudadas, a subespécie $Z$. mays mexicana apresentou um outro alelo deste mesmo tipo complexo, que é o tipo GA9TA, que não foi encontrado em nenhuma outra amostra. Baseado neste fato, acreditamos que a subespécie com maior chance de ser o ancestral direto do milho seja a Z. mays parviglumis, apoiando a hipótese de Doebley (1990).

Ainda em relação a este complexo $\mathrm{GA}_{n} \mathrm{TA}$, vemos que na amostra de milho coletada na aldeia indígena dos índios Waurá (tronco linguístico Aruak), o alelo encontrado foi o $\mathrm{GA}_{3} \mathrm{TA}$, o qual não aparece em nenhuma outra amostra analisada. Este fato pode estar indicando que pode existir mais um alelo que pode ser utilizado em estudos futuros de difusão cultural através das Américas em tempos remotos, utilizando para isto novas amostras de milho. 


\subsubsection{Considerações Finais para o Milho}

Tentamos apresentar ao longo destas últimas páginas os dados que obtivemos durante o estudo de amostras arqueológicas e de etnovariedades de milho, além das interpretações e conclusões que pudemos chegar (com a ajuda de dados e trabalhos já existentes na literatura científica).

De modo geral, o que nos propusemos de início foi tentar traçar a origem do material arqueológico de Januária, tentando estabelecer de onde ele veio e qual seria a sua relação com as demais amostras. Deste modo, todo este estudo conta parte da história evolutiva do milho. Não somos arqueólogos e nem historiadores, portanto não pretendemos esclarecer como foi o passado do homem nas Américas.

Entretanto, como o milho é uma planta altamente dependente do homem e que teve e ainda tem um papel muito importante na dieta alimentar, cultural/ religiosa em muitas comunidades humanas ao longo dos últimos milênios de história nas três Américas, acreditamos que ao termos indícios concretos do que ocorreu com o milho, podemos utilizar isto para compreender parte de nossa própria história humana.

Alguns dos dados levantados já permitem que delineemos um quadro geral de "difusão cultural" do milho na América do Sul, indicando que pelo menos duas levas migratórias principais ocorreram, em momentos históricos distintos e seguindo caminhos diferentes, criando um padrão Terras Altas/ Terras Baixas.

Podemos ver ainda, com base nos dados do milho, que as populações humanas da região ao sul da América do Sul mantinham um relativo contato cultural-comercial, enquanto a região central dos Andes (Peru), aparentemente, não teve muita influência nos materiais cultivados de milho da região das Terras Baixas, indicando que talvez a influência daquela região tenha sido menor do que historicamente se suspeitava.

Ainda, mostramos a existência na região das bacias hidrográficas do rio São Francisco e Paraná-Paraguai, de um padrão genético particular de milho, que pode estar indicando a área de influência e difusão cultural de uma cultura indígena mais recente, inclusive podendo estar relacionada com os primeiros momentos de ocupação colonial no Brasil. 
Além destes, uma série de outros detalhes, conclusões e até mesmo novas indagações são relatados no texto e não iremos relaciona-los novamente. Deste modo, acreditamos que estes dados demonstram a viabilidade do uso de amostras de plantas cultivadas no estudo do passado humano em nosso planeta. Acreditamos ainda que muito ainda se pode fazer para ampliar este estudo, principalmente no que diz respeito ao conhecimento do que ocorreu na região Amazônica e na região mais a oeste do Brasil, no sopé dos Andes. Uma ampliação deste estudo contemplando amostras destas duas regiões (modernas e, se possível, arqueológicas), poderão fornecer maiores dados e idéias sobre estas levas de colonização/ difusão na América do Sul, permitindo, talvez traçar a correta rota geográfica-temporal de chegada do milho a Januária, indicando se isto ocorreu mais pela costa Atlântica ou se foi pelo interior do Brasil.

A seguir apresentaremos os dados que obtivemos com as amostras de feijão, seguindo esta mesma linha de trabalho e análise que fizemos com o milho.

\subsection{Análise de Dados sobre as Amostras de Feijão}

Nesta parte iremos mostrar os dados que obtivemos com as amostras de feijão e as interpretações a que chegamos a partir destes.

Como dissemos na seção material e métodos, trabalhamos diretamente com 3 (três) amostras arqueológicas de Januária e 10 (dez) amostras modernas de Ph. vulgaris. Além destas, utilizamos também seqüências de $P h$. vulgaris e $P h$. lunatus que se encontram a disposição no banco mundial de seqüências (http://www.nabi.nlm.nih.gov/)

O objetivo era primeiramente determinar qual era a verdadeira espécie a que pertenciam as amostras arqueológicas, já que somente pela morfologia do grão e das duas vagens que dispúnhamos, esta determinação não era conclusiva, existindo a dúvida se elas eram Ph. vulgaris ou Ph. lunatus.

Após a determinação da espécie, caso se tratasse de Ph. vulgaris, o objetivo seria comparar geneticamente as amostras arqueológicas com as 10 amostras obtidas no banco de germoplasma do CIAT, as quais já possuem um bom nível de caracterização, apresentando características bem distintas entre si e, assim, teríamos a chance de tentar 
relacionar as amostras de Januária com algumas delas, para determinar a provável origem do material arqueológico com que trabalhamos.

Para isto utilizamos praticamente a mesma estratégia descrita para o milho, mudando apenas o gene usado como alvo e a quantidade de alvos genéticos deste gene, agora sendo dois e não apenas um.

Como mostramos na seção de revisão bibliográfica, acredita-se que o feijão comum tenha sido domesticado em mais de uma região ao longo dos Andes e América Central, independentemente (Gepts \& Debouck, 1991). Por este motivo, existem algumas características nos diferentes materiais selvagens e cultivados que variam de região para região. Este fato é muito interessante, pois permitia que tentássemos determinar qual o tipo-local a que as amostras de Januária eram mais relacionadas, indicando assim a(s) provável(is) região(ões) "fornecedora(s)" de genótipos de Januária.

O gene alvo escolhido foi o que codifica a proteína Phaseolina. A escolha deste gene se fez por dois motivos principais. $\mathrm{O}$ primeiro porque já existia um grande número de trabalhos que estudaram e caracterizaram esta proteína em feijão (Gepts, 1990; Gepts \& Debouck, 1991), mostrando que esta possui uma ampla diversidade e, em segundo lugar, porque esta diversidade varia de acordo com a região geográfica de onde as amostras foram coletadas e, portanto, se encaixava com nossos objetivos.

Duas regiões deste gene foram escolhidas como alvos para serem amplificadas e estudadas (ver detalhes na seção material e métodos). Chamaremos aqui de região PCR1 a região alvo na porção mais próxima ao final do gene e de região PCR2 a região mais central do gene.

O motivo para a escolha de duas regiões foi que enquanto a sequiência da região PCR1 permitia que determinássemos a espécie da amostra, a região PCR2 era mais propícia para visualizarmos a diversidade genética-geográfica entre os diferentes tipos desta proteína.

Antes de descrevermos os resultados e análise, chamamos novamente a atenção para o fato de que das três amostras arqueológicas de feijão que dispúnhamos, conseguimos obter DNA para análise de apenas uma (amostra P3, ou simplesmente A, de Arqueológico), como relatadas na seção 6.2.1. A consequiência principal deste fato foi 
que, deste modo, não dispúnhamos mais de nenhuma amostra pré-histórica (antes do ano de 1500), apenas de uma histórica, com idade que remonta ao final do século XVII. Entretanto, como discutimos em parte na revisão de literatura, acreditamos que esta amostra de feijão pode ser um representante do material que os índios da região cultivavam desde tempos mais remotos, já que, aparentemente, a chegada e influência dos colonizadores europeus não se fez presente na região de Januária até o início do século XVIII, como mostramos na seção de revisão bibliográfica e também confirmada pelo Dr. André Prous ${ }^{4}$. Discutiremos mais sobre este ponto mais à frente.

A seguir mostraremos os dados obtidos com as amostras de feijão, dividindo-os em duas seções, de acordo com o alvo genético utilizado (PCR1 e PCR2).

\subsubsection{Análise dos dados da região PCR 1}

Através da análise das seqüências das diferentes amostras com que trabalhamos diretamente, além daquelas que obtivemos do banco mundial de seqüências genéticas ${ }^{5}$, todas apresentadas na figura 5, pudemos primeiramente concluir que a amostra de Januária se tratava da espécie $P h$. vulgaris e não de $P h$. lunatus, como pode ser facilmente percebido quando comparamos as diferenças genéticas existentes na sequiência das bases nitrogenadas entre as duas espécies, conseqüência direta do processo de especiação ocorrido entre as duas espécies durante o processo de evolução. Esta divergência genética entre elas será melhor comentada na seção em que analisamos a região PCR 2.

Este fato foi de suma importância, pois permitiu que pudéssemos analisar a região PCR 2 com os objetivos propostos, já que a diversidade geográfica esta muito mais presente e caracterizada pela literatura dentro da espécie $P h$. vulgaris do que na $P h$. lunatus.

\footnotetext{
${ }^{4}$ Prous, A (UFMG- Belo Horizonte) Comunicação pessoal, 2000.

${ }^{5}$ http://www.nabi.nlm.nih.gov/
} 
Além da determinação da espécie, a região PCR 1 também permitiu que pudemos constatar que o tipo da proteína Phaseolina presente na amostra de Januária era do tipo " $\alpha$ " e não do tipo " $\beta$ ".

Segundo Kami \& Gepts (1994) a proteína Phaseolina possui dois tipos básicos (tipos “ $\alpha$ ” e “ $\beta$ "). Ainda segundo estes mesmos autores, estes tipos provavelmente surgiram, divergiram, há muito tempo atrás, antes que a espécie selvagem tivesse se expandido, colonizando a área ampla em que ela ocorre atualmente, desde o México até o sul da América do Sul, e até mesmo antes de que esta espécie tenha sido domesticada pelo homem. Isto é alegado porque os dois tipos estão muitas vezes presentes em diversas amostras pertencentes a uma mesma etnovariedade em uma mesma região geográfica, e ocorrem em toda a região onde a espécie selvagem existe naturalmente, mostrando que estes tipos não são exclusivos de uma determinada região geográfica.

A diferenciação entre os dois tipos se dá principalmente pela presença de uma pequena repetição direta (27 bp) no tipo “ $\alpha$ ” e a ausência desta no tipo “ $\beta$ ”. Esta repetição ocorre na posição 1318 do gene, como um todo, segundo Kami \& Gepts (1994) e está na posição 148, nas seqüências apresentadas na figura 5.

Gostaríamos de ressaltar que esta divisão dos tipos de Phaseolina em dois grupos, difere daquela divisão apresentada na Tabela 2, na seção de revisão bibliográfica e que possui ao redor de 10 tipos diferentes. Esta última divisão é feita basicamente através da separação de padrões distintos de corridas de extratos da proteína Phaseolina em gel de eletroforese (Gepts et al,1986; Gepts, 1990; Gepts \& Debouck, 1991), a qual aparentemente possui um padrão geográfico, fazendo com que determinados tipos ocorram preferencialmente em determinadas etnovariedades e locais específicos (figura 9). E foi baseado nesta diversidade de tipos e padrões geográficos que baseamos nossas análises para a região PCR 2, que será discutido em seguida. 


\subsubsection{Análise dos dados da região PCR 2}

Como dissemos anteriormente, o objetivo do estudo do alvo PCR 2 era comparar os diferentes tipos de padrões de Phaseolina com a da amostra arqueológica, para tentar relacionar, se possível, a amostra de Januária com determinados tipos e locais geográficos, buscando compreender a história de influência humana e alimentar naquela região do norte de Minas Gerais.

Através da literatura vemos que existem ao redor de 10 tipos diferentes desta proteína já descritas, que estão representadas na figura 9, as quais, algumas delas, aparentemente evoluíram mais recentemente, durante o processo de domesticação desta espécie sob pressão evolutiva do próprio homem, o qual acabou influindo na criação destas etnovariedades locais, surgindo, deste modo padrões regionais, os quais agora podemos usar em nossas análise Gepts et al,1986; Gepts, 1990; Gepts \& Debouck, 1991).

Para a análise filogenética-geográfica, pegamos todas as sequiências genéticas desta região do PCR 2 que obtivemos em nosso estudo, as quais já tínhamos conhecimento prévio de qual era o tipo de Phaseolina que elas possuíam (com exceção da amostra arqueológica), juntamos com as sequiências obtidas do banco mundial, as quais também já possuíam o tipo da proteína caracterizado, e as agrupamos num gráfico de "network", mostrado na figura 10.

O fundamento deste gráfico é o mesmo exposto para o caso do milho, onde através dele podemos ter uma boa idéia da relação filogenética existente entre as diferentes amostras, mostrando qual é a proximidade entre cada um dos alelos e tipos de Phaseolina, além de visualizarmos quais são as mutações que as separam. 
Figura 9 - mapa com tipos phaseolina

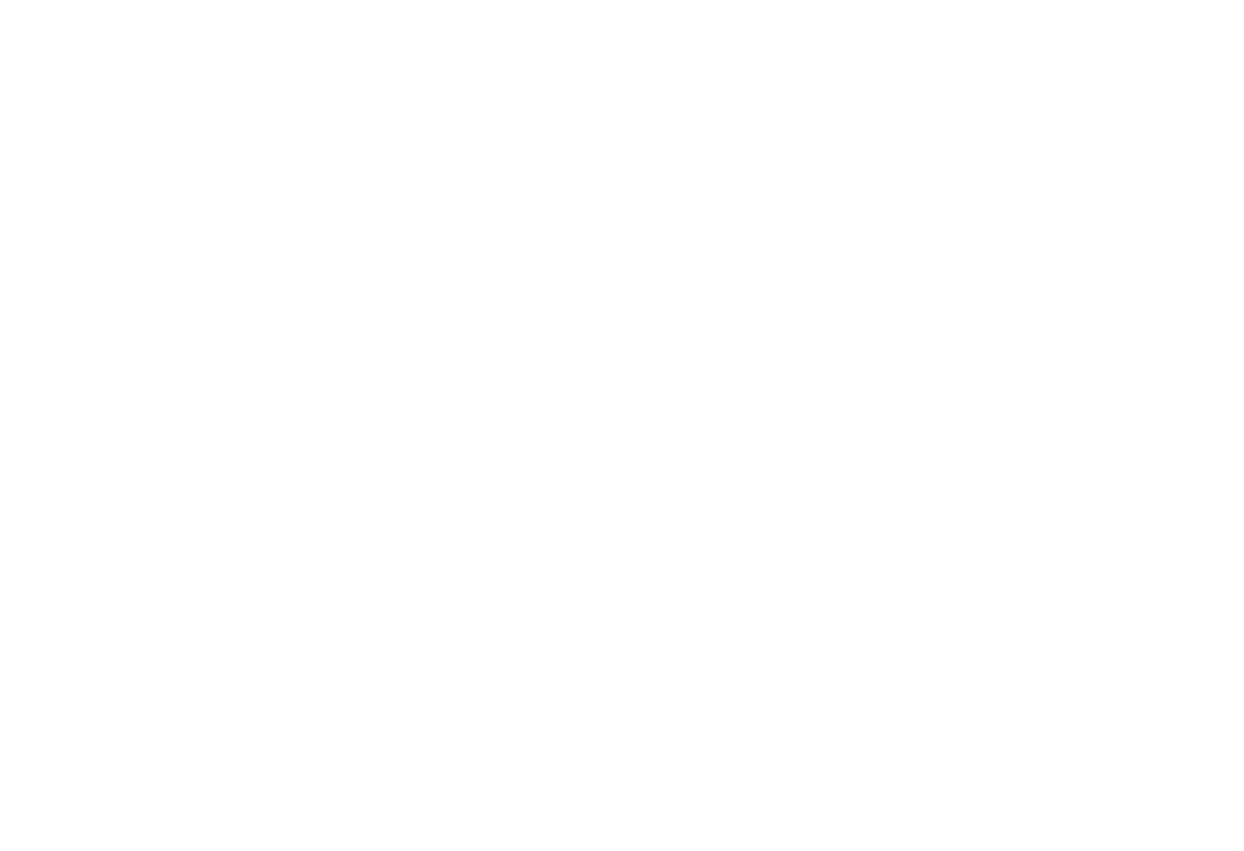


Figura 10. Network de feijão PCR2

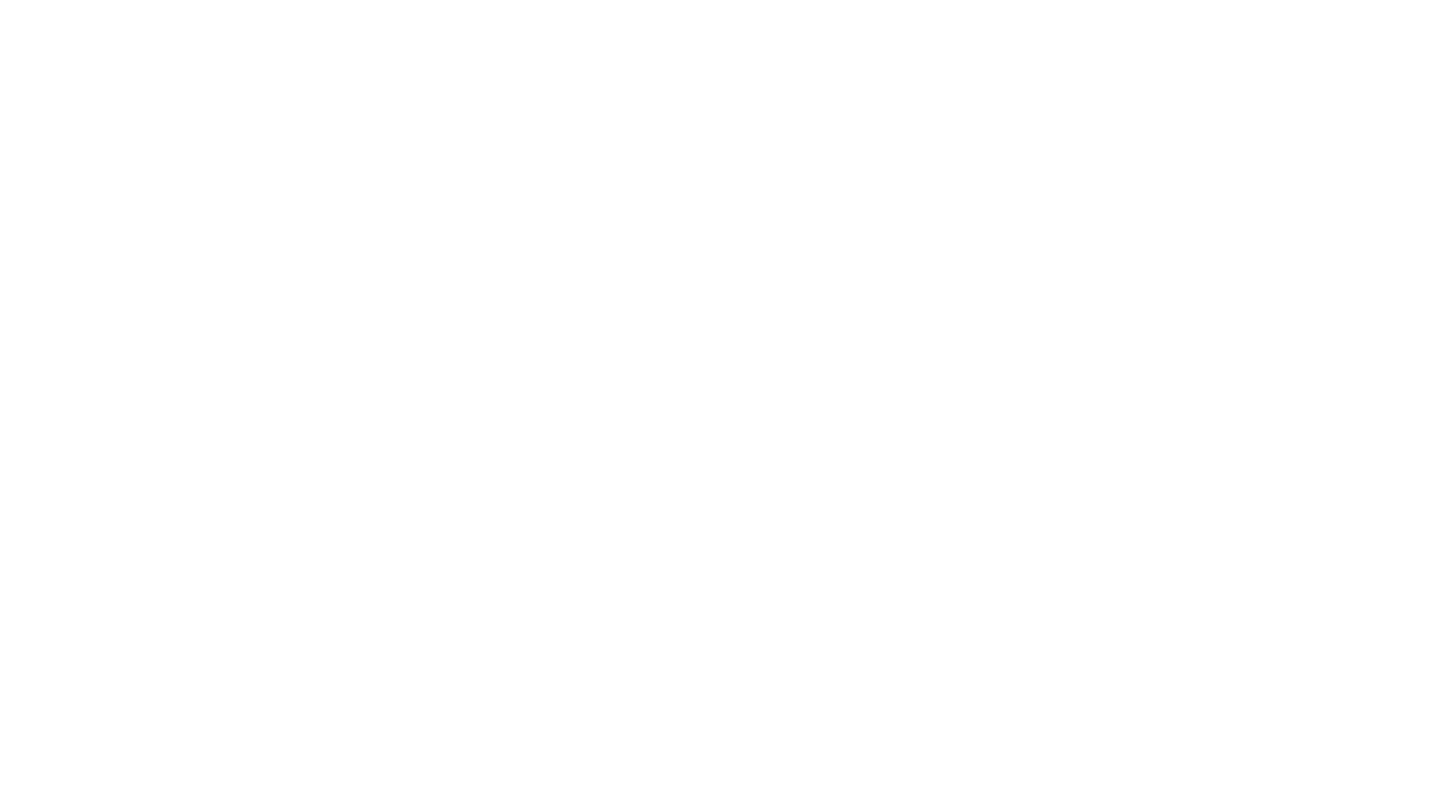


Através do gráfico de network apresentado na figura 10, podemos fazer uma série de considerações. A primeira delas diz respeito ao grau de divergência, isolamento entre as duas espécies de feijão.

Pelo gráfico vemos que os dois alelos mais próximos existentes entre as duas espécies de feijão - Ph. vulgaris e Ph. lunatus são o B 10-2, da Colômbia e o UO 1121, respectivamente (situados no lado esquerdo da figura). O número de mutações divergentes entre estes dois alelos é igual a 37, ou seja, entre as 280 bases nitrogenadas existentes nesta sequiência de parte deste gene, as duas espécies diferem em no mínimo 37 bases. É um número relativamente alto, principalmente se fizermos a mesma comparação entre as diferentes espécies do gênero Zea, mostrada na figura 7, onde veremos que, por exemplo, a espécie Tripsacum pilosum, que é de outro gênero, não diverge mais do que 10 bases nitrogenadas da sequiência de milho mais próxima.

Isto pode estar indicando duas possibilidades, em nossa opinião. A primeira, considerando que a taxa evolutiva para todas as espécies é constante (o que não é verdade), que estas duas espécies de feijão evolutivamente podem ter divergido a partir de um ancestral comum há muito mais tempo do que as espécies relacionadas ao milho. Este tempo maior teria permitido um maior acumulo de mutações entre ambas espécies.

Uma segunda possibilidade, ignorando o tempo de divergência entre as espécies, é de que a pressão de seleção sobre o gene $A d h 2$, do milho é muito maior do que a que ocorre para o gene da Phaseolina, no feijão. Caso isto esteja correto, isto significa que o gene da Phaseolina esta muito mais livre para, caso sofra uma mutação, manter o novo alelo mutante, enquanto no caso do milho, qualquer novo alelo do gene $A d h 2$ gerado por mutação tende a se extinguir, a não ser que confira reais vantagens à espécie. Este último caso pode ocorrer quando um gene é muito essencial ao organismo e sua estrutura tem que ser muito precisa e, portanto, somente aquelas novas mutações (alelos) que não causem prejuízo à função do gene é que poderão ser mantidas, enquanto as outras são eliminadas por seleção natural. Neste caso, a seqüência do gene tende a ser mais estável. Outras situações intermediárias são cabíveis. 
Lembramos também que o feijoeiro é uma espécie autógoma, ou seja, possui taxa de autofecundação elevada, enquanto o milho é alógoma, com maior taxa de cruzamento, recombinações entre plantas distintas.

Seja qual for o caso, já que a elucidação deste problema não é aqui nosso objetivo específico, o fato é que podemos constatar que este gene das duas espécies de feijão está relativamente separado, em termos de história evolutiva, onde a seqüência (alelo) ancestral se encontra em algum lugar entre estas 37 mutações, podendo ser mais próxima de uma ou de outra espécie, dependendo de como tenha sido o rumo evolutivo tomado por cada uma delas.

Mais ainda, a utilização da espécie Ph. lunatus como um "out group”, nos permite sugerir que os primeiros alelos da recém-formada espécie $P h$. vulgaris deveriam ser muito próximos ao que é hoje encontrado nesta amostra de feijão da Colômbia. Isto não quer dizer que esta espécie tenha se originado na Colômbia, mas sim que esta amostra (B 10-2) possui um alelo tipo ancestral, muito antigo, que é vestígio dos primeiros alelos existentes naquela então nova espécie. Este alelo deve estar próximo a "raiz" da árvore evolutiva desta espécie.

Seguindo esta mesma linha de raciocínio, ao observarmos a figura 10, podemos dizer que quanto mais afastados os alelos se encontrarem do "alelo-base" (B 10-2), e por conseguinte da seqüência (alelo) ancestral da espécie, da raiz desta árvore evolutiva, mais novos eles tendem a ser, em termos de evolução. Por exemplo, o alelo T 8-1 (no canto inferior direito da figura 10) é provavelmente um dos alelos mais recentes deste gene dentro da espécie e poderíamos figurativamente representá-lo como sendo o ápice dos galhos da árvore genealógica da espécie.

É como se pudéssemos ver a evolução ao longo do tempo, com os primeiros alelos surgindo na raiz desta árvore e, à medida que esta foi crescendo, evoluindo, divergindo, novos alelos foram surgindo, originando os novos galhos, ramificações.

A partir deste ponto, iremos interpretar a dinâmica evolutiva deste gene, dentro da espécie Ph. vulgaris, baseados na relação filogenética existente entre os alelo, que estão plotados na figura 10 . 
Podemos dividí-la em duas partes: A primeira que chamaremos de "anel", e que está delimitado pelas linhas vermelhas e, a segunda parte que chamaremos de "ramificação", nas linhas em preto.

Antes de entrarmos diretamente na análise destas duas regiões da figura, gostaríamos de relembrar algumas propriedades da teoria evolutiva, as quais serão muito úteis para a análise que faremos em seguida ${ }^{6}$.

O termo diversidade/ variabilidade pode ser resumido como sendo opções de uma mesma coisa, ou seja, quanto mais opções/ variações possuirmos sobre determinado caráter, maior será sua variabilidade. Um exemplo infantil pode ser a cor de uma bola, onde pode-se ter diversas bolas apenas da cor branca ou pode-se ter para cada bola uma cor diferente.

A mesma coisa se aplica a um gene de um organismo. Este gene pode ter somente um alelo (uma só cor), ou ter vários alelos (várias cores). Esta variabilidade é gerada basicamente por mutação, ou seja, a partir de um alelo base, novos alelos podem surgir através da mudança da seqüência deste gene, criando assim novas seqüências, novos alelos, ou uma nova cor, segundo nosso exemplo.

Alem da mutação, a qual acarreta a mudança de determinados nucleotídeos em pontos específicos da seqüência do gene, outra forma de geração de variabilidade é através da recombinação genética, ou seja, dois alelos diferentes de um mesmo gene trocam partes de suas sequiências entre si, criando assim um terceiro alelo, que é um híbrido entre os dois alelos originais (como se misturássemos duas cores já préexistentes para criar uma terceira).

Resumindo, a mutação cria uma mudança nova nas bases nitrogenadas da seqüência do gene, enquanto o processo de recombinação mistura estas mutações, criando novas combinações.

Fizemos este adendo para mostrar que ao analisarmos os diferentes alelos presentes em um grupo de amostras de uma espécie, temos que ter em mente que

\footnotetext{
${ }^{6}$ Martins, P.S. (ESALQ-USP) Comunicação pessoal, 1992-1997.
} 
historicamente estes dois fatores estavam agindo, podendo ser mais um do que outro, dependendo de como foi a dinâmica evolutiva de uma dada população.

Por exemplo, populações diferentes que mantêm contato e trocam genes, ou seja, se recombinam, tendem a ter seus alelos mais homogêneos, pois qualquer mutação que aparecer em uma das populações, será passada para a outra, por cruzamento.

Entretanto, para aquelas populações mais isoladas, que raramente trocam genes com outras populações, qualquer nova mutação que surgir nesta população tende a ficar confinada aos indivíduos pertencentes somente a esta dada população, não sendo distribuída a outras e vice-versa, ou seja, as mutações originadas nas populações de "fora" não chegam até ela e nem a delas chega às outras.

Está é a base de nossa análise que faremos em cima da distribuição de alelos encontrados nas diferentes amostras e que estão organizados na figura 10. Pela figura vemos a existência de um grande número de alelos, sendo alguns destes compartilhado por diferentes indivíduos, de populações diferentes, como é o alelo presente no circulo "consensus", o qual ocorre em pelo menos 6 indivíduos de populações diferentes, e outros alelos ocorrendo em apenas um indivíduo, exemplo A8.

Para explicar a estrutura vista nesta figura, dividimos esta em duas partes, um chamado "anel" e o outro de "ramificação", como mencionada acima. Analisaremos agora cada um deles.

O "anel”. A razão para chamarmos esta parte delineada pela cor vermelha do gráfico de anel é porque as amostras/ alelos presentes ao longo desta região aparentemente possuem uma inter-relação muito grande.

Podemos ver a presença de um grande número de alelos nesta região que, como explicamos é em parte gerada por mutação. Entretanto, muitos dos alelos presentes neste anel podem ter surgido por diferentes "caminhos" evolutivos.

Por exemplo, assumindo que o alelo 10-2 (Phaseolina tipo "B") é o tipo ancestral, como comentamos anteriormente, o alelo 16-4 (Phaseolina tipo "M") pode ter se originado a partir daquele por diferentes etapas ou seqüências de mutação. Pode ter sido pelo surgimento de uma mutação na posição 110 do gene, seguida por outra na 
posição 46 e depois por outra na 41. Outra rota possível é primeiramente ter ocorrido uma mutação na posição 246, depois 41 e 110. Pode ainda ser outra rota: 246; 41; 155; 110; 155. Ou outra: 41; 246 e 110.

Diversos são os caminhos evolutivos possíveis de terem criado este alelo e esta é a grande vantagem do gráfico de "network", pois permite que tenhamos uma visão das reais possibilidades do que pode ter ocorrido de fato. Esta diversidade de alelos compartilhando algumas mesmas mutações e estando filogeneticamente ligados por diversos caminhos ou rotas evolutivas possíveis, os quais podemos observar em diversos alelos da figura, não podem ser explicados exclusivamente pela ocorrência de mutações. Isto deve ser o reflexo de recorrentes eventos de recombinações, os quais permitiram a mistura destas novas mutações que foram surgindo ao longo do tempo.

Ou seja, queremos dizer que as diferentes populações de feijão que continham estes alelos do anel estavam provavelmente em contato periódico, trocando alelos. Não eram populações isoladas.

Já no caso dos alelos situados na parte "ramificação" do gráfico, vemos nitidamente que eles surgiram a partir de alelos presentes no "anel" e depois divergiram mais isoladamente, ou seja, aparentemente o(s) alelo(s) fundadores de todos os outros alelos presentes na parte ramificada surgiram a partir de poucos alelos presentes no anel. E, após surgirem, ou terem fundado estas novas populações, estas ficaram relativamente isoladas em relação as outras populações de alelos do anel, fazendo com que as novas mutações que foram surgindo nas populações da ramificação ficassem mais confinadas a elas, além destas também não receberem com muita freqüência novos alelos do anel, o que faria com que os alelos ficassem mais homogêneos, caso este contato estivesse ocorrendo de forma mais recorrente.

Visto a diferença encontrada entre as duas regiões da figura e, particularmente, pela configuração da parte ramificada, que possui por um lado sua origem (no anel), e do outro os alelos mais novos, em expansão, estando estes na ponta da figura, sem comunicação com nenhum outro alelo da parte central da figura, indicando que estão 
evoluindo separadamente aos demais, demostra que estes alelos são mais recentes do que os do anel.

Quando somamos a estes dados o fator geográfico, vemos um cenário bastante interessante. Geograficamente, todas as amostras da região do México, Colômbia e Equador/ norte do Peru (Phaseolinas tipo M, S, B, CH e I), se encontram na região do anel, enquanto, na região ramificada, estão presentes apenas amostras do sul do Perú e da Argentina (Tipos C, H, T, P, J). Vemos ainda alguns alelos tipo T e um tipo P também ocorrendo na região do anel, o que comentaremos adiante

Este fato está sugerindo que os alelos das populações de feijão das regiões do México até o norte da América do Sul (Colômbia- Equador), historicamente devem ter estado em freqüentes contatos, pois são muito mais relacionados e formam um grupo a parte daquele outro formado pelos alelos encontrados do Peru para o Sul do continente.

Podemos dizer baseados nas evidências encontradas nos alelos deste gene, que a espécie $P$. vulgaris deve ter surgido em algum local entre o México e a ColômbiaEquador e, nesta região a espécie foi evoluindo, criando diversidade, onde novos alelos e tipos da proteína Phaseolina foram surgindo e sendo selecionadas (inclusive algumas pela ação do próprio homem) e, posteriormente, alguns acessos de feijão acabaram chegando mais ao sul do continente, colonizando a região do Peru até Argentina .

Isto aparentemente vai de encontro com a hipótese de múltiplos centros de origem para o feijão, como sugerido por outros pesquisadores e que já relatamos anteriormente. Segundo nossos dados, vemos que a origem do feijão deve ter ocorrido através de um único evento de evolução/ diferenciação e todos os outros tipos de feijão atualmente encontrados foram originados a partir deste primeiro evento.

Acreditamos ainda que o local de origem se encontra provavelmente confinado entre o norte da América do Sul e o México, sendo que as populações da região do Peru e ao sul surgiram a partir de populações desta região mais ao norte, ficando posteriormente mais isoladas do que as populações da região norte. Ou seja, os diferentes tipos desta proteína de feijão hoje encontrado não devem ser conseqüência de múltiplos eventos de seleção natural e artificial (pela ação do homem), mas sim devido a divergência de algumas populações que, depois de terem surgido a partir de um ancestral 
comum, ficaram relativamente isoladas, permitindo desta forma que se diferenciassem, criando padrões locais distintos.

Cabe neste momento uma consideração do tipo que fizemos quanto ao milho, ou seja, muitas destas populações de feijão foram manipuladas pelo homem pré-histórico e ele foi fundamental em diversos pontos da evolução desta planta, assim como de muitas outras espécies domesticadas. $\mathrm{O}$ homem seleciona as características que deseja para a planta, mas, em nosso caso, o mais importante é que o homem tem a capacidade de levar e difundir estas plantas para onde ele for, podendo colocar lado a lado plantas que a princípio estariam isoladas por grandes distâncias, permitindo que ocorra recombinação entre estes materiais, assim como populações humanas que forem muito fechadas, acabem por criar plantas com características particulares (carregando alelos singulares), os quais acabam não sendo compartilhadas, repartidas com outras populações humanas e de plantas.

Portanto, o que queremos dizer, é que estes dois grandes grupos que vemos na figura 10, que geograficamente representam, simplificadamente, populações do norte e do sul, devem ser reflexo direto da ação do homem, no passado. Deste modo, aparentemente a razão para que os alelos das populações de feijão existentes entre o México até a Colômbia- Equador serem mais homogêneos significa que havia um grande contato, comércio ou troca cultural e alimentar entre as populações humanas que viviam nesta região.

Por outro lado, aparentemente as populações humanas da região do Peru para o Sul da América do Sul, além de virem a conhecer o feijão posteriormente, aparentemente, após esta aquisição, ficaram relativamente isoladas das outras, ou mantiveram um possível isolamento que já existia. Deste modo, isto significa que a presença de dois grandes grupos de populações de alelos de feijão reflete provavelmente a existência de pelo menos dois grandes grupos culturais humanos, os quais mantinham um certo nível de contato dentro de cada grupo, mas em nível menor entre os dois grupos. 
Novamente repetimos o que já dissemos quanto ao milho, ou seja, aparentemente as barreiras culturais humanas foram muito mais fortes, importantes e decisivas na origem, seleção e difusão dos gêneros animais e vegetais que o homem utilizava em seu dia a dia, no passado, do que as própria barreiras geográficas.

Existem ainda algumas considerações que podemos tirar da figura. Podemos ver que alguns tipos da proteína Phaseolina possuem alelos nas duas partes da figura, como é o caso do tipo T, P, J e H. Como dissemos anteriormente, o gene da Phaseolina é na verdade um complexo de multigene, podendo haver no mínimo 6 pares deste gene dentro de cada genoma da célula. Deste modo, acreditamos que alguns destes genes podem manter alelos mais antigos enquanto outros genes do mesmo genótipo (mesmo indivíduo) podem ter os alelos mais novos. Assim, caso estes tipos de Phaseolina da região Sul sejam realmente originados de tipos da região norte, é possível que as primeiras formas dos alelos que deram origem aos novos tipos do Sul ainda possam estar preservados em alguns destes genes e isto explicaria o porque da ocorrências de alelos de populações de um tipo de proteína com alelos nos dois setores do gráfico.

Além disto, é bem provável que, historicamente estes duas regiões tenham variado o nível de relacionamento ao longo destes últimos milênios, com momentos de maior contato e outros de maior isolamento, fazendo com que pudessem ocorrer algumas trocas e difusões de materiais entre uma região e outra, promovendo a recombinação de alelos por ventura novos. Novamente lembramos sobre o papel do homem como difusor destas plantas e as barreiras culturais.

Destes tipos, o que mais chama nossa atenção é o tipo $\mathrm{T}$, onde vemos alelos nitidamente dentro da região do anel, inclusive compartilhando alelos com o tipo M e I, e ainda possui alelos na extremidade da figura, evidenciando alelos muito novos. Muitos podem ser os fatores que explicam isto e somente com estes dados não temos condições de afirmar qual delas é a realidade, mas podemos fazer algumas conjecturas ou hipóteses para isto.

Uma delas se baseia no trabalho de Gepts \& Debouck, (1991) e que mostramos na tabela 2. Nela vemos que atualmente a Phaseolina tipo $\mathrm{T}$ se encontra em populações 
de material cultivado de feijão disperso desde o México (8\% dos tipos de Phaseolina encontrados nas plantas nesta região), passando pela Colômbia (26\%), e sendo o principal tipo que ocorre no Peru (50\%), sendo ainda que em materiais selvagens, o tipo T só é encontrado na região dos Andes Centrais e Sul, portanto não encontrado na Colômbia e menos ainda no México.

Isto sugere que a origem do tipo $\mathrm{T}$ se deu nos Andes e, posteriormente ele foi difundido para o norte. Esta larga distribuição permite com que algumas populações que se encontrem mais próximas ou mesmo em simpatria com populações de outros tipos de Phaseolina entrem em contato e se cruzem, se recombinem, trocando alelos, fazendo com que possamos encontrar uma maior diversidade de alelos em amostras do tipo T, inclusive com alelos próximos aos do tipo da região norte.

Antes de discutirmos as amostras arqueológicas, o que é o verdadeiro objetivo desta tese, gostaríamos de fazer apenas mais um comentário sobre o material de Phaseolina do tipo "I". Kami et al (1995) dizem que, através do padrão de testes de isoenzimas, o tipo I encontrado no Equador apresenta um padrão intermediário entre todos os outros tipos de Phaseolina encontradas no México - Colômbia e dos tipos do resto da região dos Andes. Na interpretação destes autores, eles dizem que isto pode significar duas coisas, ou que este tipo é um tipo muito antigo, ancestral, o qual originou todos os outros tipos de Phaseolina, sendo que a partir desta região o feijão se espalhou, criando novos tipos em outras regiões, ou que este padrão intermediário é devido a uma mistura entre tipos destas duas regiões. Acreditamos na segunda hipótese, baseados nos dados plotados na figura 10 e nos comentários que já apresentamos anteriormente.

Finalmente, em relação a amostra arqueológica de Januária, foram observados a presença de 6 alelos diferentes, que se encontram relativamente distribuídos pelo gráfico de network.

Dois dos alelos são iguais ao encontrados em outras amostras. O alelo A-10 é o mesmo encontrado em outras 3 amostras distintas de Phaseolina, sendo estas últimas todas do tipo S (17-6; u01132; x52626), típicas do México. 
Ainda, o alelo A-13 também esta presente em indivíduos com phaseolina tipo B (10-1); tipo CH (12-3); tipo M (16-3) e, novamente do tipo S (17-4 e u01131), sendo todos estes tipos típicos de genótipo encontrados na região norte, ou seja, do México até a Colômbia.

Todos os outros 4 alelos presentes nas amostra de Januária são exclusivos, ou seja, ocorrem somente nesta amostra, não tendo sido encontradas em nenhuma outra amostra contemplada neste estudo.

Mesmo sendo exclusivas, podemos notar que elas ocorrem mais ou menos ao redor da região do anel, como é o caso da amostra A-12, que possui apenas uma mutação divergente em relação ao anel. Como dissemos anteriormente, é no anel onde se encontram os tipos de Phaseolina pertencente geograficamente a região que simplificadamente chamamos de Norte.

Ou seja, em um primeiro momento, o nosso ímpeto é afirmar que a amostra de Januária possui sua origem a partir de populações da região norte, sugerindo que o material de feijão cultivado em Januária veio do extremo norte da América do Sul e não dos Andes Centrais, como aparentemente foi o que ocorreu com o material de milho, relatado anteriormente. Entretanto, dois ou três dos alelos de Januária nos chamam a atenção.

Por exemplo, o alelo A-8 possui apenas uma mutação divergente do alelo 14-1, com Phaseolina tipo P (o qual possui ocorrência também nos Andes Centrais), sugerindo um certo grau de relação entre eles. Além disto, o alelo A-9 está próximo ao início da parte ramificada, onde se encontram os alelos dos Andes Centrais e do Sul.

A não ocorrência de nenhum alelo da amostra de Januária na região ramificada do gráfico sugere que a região dos Andes Centrais e Sul não foi a região de maior influência na formação do genoma que chegou ao Vale do Rio São Francisco, mas ela pode ter contribuindo em parte, como demonstram os dois últimos alelos.

Podemos imaginar alguns cenários que podem explicar este fato, ou seja um grande fator da região norte e uma parte da região sul.

Um primeiro cenário seria onde as amostras que chegaram à Januária saíram de uma população de feijão que se encontrava no limite de influência entre a região Norte e 
a Sul, contendo alelos típicos das duas regiões. A ausência de alelos de Januária mais na "ponta" do gráfico, na parte ramificada, pode ser explicada desde pelo "efeito fundador", onde a amostra que foi retirada daquela população não continha todos os alelos que realmente estavam presentes na população, ou seja foi um "erro" de amostragem ou os alelos mais típicos ou exclusivos da região sul realmente não se encontravam presentes nos genomas da população de onde a amostra saiu.

Ainda neste mesmo cenário, pode ser o caso desta amostra que alcançou Januária ter saído daquela região há muito tempo atrás, antes de que os novos alelos típicos do sul tenham sido formados.

Outro cenário seria que a amostra é um híbrido, que se formou já em território brasileiro, ou fora das duas áreas de influência, ou seja, amostras de feijão da região norte foram cruzadas com amostras da região sul, em algum lugar e, destes descendentes, uma parte chegou a Januária.

Seja qual for o cenário real que aconteceu, o fato é que no genoma da amostra de feijão de Januária, esta possui em sua base genética alelos muito antigos, os quais acreditamos que tenham se originado em algum lugar entre o México e a Colômbia, como argumentamos anteriormente. A presença de alelos mais próximos a alelos típicos da região Central e Sul dos Andes pode ser explicada de diversas maneiras, sendo que não é necessário que a amostra de Januária tenha passado ou vindo diretamente de algum local da região Sul, mas que apenas deve ter tido contato em algum lugar com populações que possuíam alelos com algum grau de parentesco ou similaridade com os da região Sul.

Por exemplo, imagine uma população indígena que habitava o norte da Venezuela e que cultivava feijões que recebeu de seus parentes da Colômbia. É bem provável que este feijão contenha em sua maior parte, se não em toda, alelos típicos da região norte. Entretanto, imagine que em um dado momento esta mesma população indígena recebe ou troca, ou devido a disputas territoriais consegue algumas vagens de feijão de uma região mais ao Sul. Neste momento, poderiam estar sendo introduzidos alguns alelos mais típicos aos encontrados em populações de feijão no Peru, Bolívia ou 
mesmo Argentina. Este novo tipo acaba cruzando com o tipo já existente, formando um genótipo híbrido, com parte de alelos do Norte e parte do Sul, digamos meio a meio.

Entretanto, este híbrido depois de crescer vai se cruzar e, neste momento, ao redor dele, provavelmente vai haver muito mais plantas com alelos tipo do Norte do que do tipo do Sul, já que culturalmente esta tribo indígena historicamente sempre cultivou mais feijão do primeiro tipo, segundo nosso exemplo hipotético e, como acontece até hoje nas diversas populações indígenas, estes povos não abandonam seus cultivares tradicionais por algum novo de uma hora para outra. Eles primeiro experimentam e muito. Assim, aqueles alelos novos que foram introduzidos, aos poucos acabaram sendo diluídos cada vez mais, com as sucessivas gerações de cruzamento (ou em termos genéticos, retrocruzamentos).

Tempos depois, algumas sementes deste local são levadas para novas regiões e acabam chegando em Januária e, ao analisá-las vemos a presença maior de um determinado padrão de alelos, mas com traços de outros, que é o reflexo de eventos históricos que ocorreram no passado não apenas desta plana, mas das culturas humanas que a utilizaram.

Não pretendemos de forma alguma pedir para que acreditem que foi assim que aconteceu com a amostra estudada, apenas produzimos um dos cenários possíveis. Pedimos desculpas neste momento se por diversas vezes ao longo desta tese saímos da interpretação dos fatos puramente científicos e fugimos para debates no campo da especulação e imaginação. Isto se deve ao fato de que estamos tentando recompor a história não apenas de uma espécie, no caso do feijão ou mesmo do milho, mas sabendo que esta história esta intimamente ligada a história do próprio homem, o que conturba ainda mais qualquer interpretação dos fatos.

Ligado a isto, a ocorrência de escassos vestígios arqueológicos e trabalhos nesta área, fazem com que tenhamos que trabalhar tentando preencher de forma mais plausível possível imensas lacunas, tanto no tempo, como no espaço. Por exemplo, entre a Colômbia, Andes Centrais e Januária existe um espaço de mais de $4.000 \mathrm{~km}$ em linha reta! Uma série de eventos podem ter ocorrido no meio deste caminho e somente com 
uma maior riqueza de amostras, para que possamos buscar mais dados, é que poderemos realmente falar qual dos cenários foi de fato o que ocorreu, ou mesmo um outro.

Deste modo, em nossas considerações finais nesta discussão, primeiramente gostaríamos de fechar a discussão sobre o feijão e, em seguida, analisar os dados da tese com um todo.

Assim, baseados agora somente em termos genéticos, verificamos que a amostra de feijão de Januária possui a maioria de seus alelos mais próximos aos alelos presentes em populações encontradas desde o México até o norte da América do Sul mas possuindo também alguns alelos mais intermediários, sugerindo um certo grau de influência da região dos Andes Centrais e do Sul no genótipo de Januária.

Em relação à idade deste material, que remonta ao final do século $17 \mathrm{e}$, deste modo pode se tratar de uma introdução mais recente, por parte dos colonizadores, nos baseamos apenas nos relatos históricos existentes sobre a investida dos colonizadores sertão a dentro. Pelos dados históricos existentes, os primeiros europeus só conseguiram alcançar esta região do Rio São Francisco ao redor do final do século 17 e a colonização se fez mais intensa somente em meados ou final do século 18, com a descoberta das minas de ouro em Minas Gerais.

Assim, a presença de grãos de feijão no interior de uma pequena caverna ou gruta, em um local que está distante mais de $40 \mathrm{~km}$ do Rio São Francisco, o qual servia como "estrada" natural e sabendo que o feijão é uma planta tipicamente domesticada e cultivada por nativos americanos, sendo que os europeus somente vieram a conhecer o feijão após a chegada dos primeiros colonizadores, há 500 anos, faz com que acreditemos que estas amostras de Januária representam etnovariedades que já deviam ser cultivadas naquela região desde tempos mais remotos.

Este fato é reforçado quando vemos que a região de Januária era habitada por tribos indígena pertencentes ao tronco linguistico Gê, como as tribos Xavantes, Xerentes e Xacriabas, sendo estes últimos ainda habitantes desta região. Historicamente, estas tribos eram inimigas das tribos de origem Tupi, que habitavam o litoral brasileiro e estavam mais em contato com os colonizadores. Isto sugere que caso tribos indígenas do litoral tenham obtido novas amostras de feijão introduzidas pelos colonizadores, estas 
amostras teriam dificuldade de serem difundidas para as tribos mais do interior, por meio de trocas, visto que eram inimigas. Somente poderia ocorrer por meio de guerras. Este fato faz com que a difusão de possíveis materias que tenham sido introduzidos na costa leste tenham provavelmente tido uma certa dificuldade de difussão para o interior do Brasil, devido as barreiras culturais então existentes ${ }^{7}$.

Entretanto, temos a consciência de que somente com novas amostras deste local, com idades superiores a 500 anos e que possuam DNA para análise, é que poderemos realmente afirmar algo mais concretamente.

Entretanto, cabe aqui ressaltar que a hipótese de difusão e chegada de feijão em Januária vindo mais pelo norte do continente é corroborada com os dados que apresentamos com relação ao milho, o qual possui amostras tipicamente pré-históricas e, portanto, não sofreu nenhuma influência dos colonizadores europeus, somente das culturas indígenas que aqui habitavam e interagiam, seja pacificamente ou não.

De modo geral, acreditamos que o objetivo primeiro, que era tentar colaborar no conhecimento de qual foi o histórico das populações humanas que viveram na região do Vale do Peruaçu, no município de Januária, no médio São Francisco, foi mais enriquecido.

Os dados responderam algumas questões mas também geraram outras, o que é estimulante, já que estas novas dúvidas apresentam caminhos mais precisos a serem explorados, permitindo que desconsideremos outros que, antes da geração destes dados desta tese, também eram possíveis.

Desta forma, fazemos votos que esta tese possa servir como fonte de dados e consultas para outros pesquisadores, os quais também vem trabalhando e se esforçando para trazer a luz da ciência de hoje parte do passado da cultura dos nossos antepassados, seja em suas andanças ou comilanças.

\footnotetext{
${ }^{7}$ Ramos, F.A. (FUNAI-Brasília) Comunicação pessoal, 2000.
} 


\section{CONCLUSÕES}

A seguir apresentaremos as principais conclusões obtidas nesta tese, dividindo-as entre gerais, sobre o milho ou sobre o feijão.

- Primeiramente podemos afirmar que amostras arqueológicas vegetais de regiões tropicais podem preservar material genético e estas podem ser usadas em análises científicas.

- A análise genética baseado em gráficos de "network" se apresentou como sendo uma ferramenta muito precisa, clara e didática, para análise e interpretação de dados sobre estudos de filogenia.

Milho

- Este material genético estava preservado não apenas nas sementes, os quais são conhecidos pela propriedade de melhor preservação de material genético, como também em outros tecidos, como o sabugo e a palha do milho, onde obtivemos DNA preservado e apto para analises.

- Três padrões/grupos principais de alelos do gene Adh2 foram encontrados no milho.

- Os três padrões foram encontrados na América do Sul, mas não homogeneamente distribuídos. Um primeiro tipo, aparentemente o mais simples, primitivo, está presente praticamente apenas na região da Cordilheira dos Andes. Os outros dois tipos se fazem mais presentes na região das terras baixas da América do Sul, sendo que um deles se encontra somente na parte leste do continente, ao longo das bacias hidrográficas dos rios São Francisco e Paraná-Paraguai. 
- Este padrão terras altas/ terras baixas é um fenômeno antigo, como demonstram as amostras arqueológicas.

- Este padrão terras altas/ terras baixas indica a ocorrência de duas levas principais e independentes de entrada, difusão de raças/ etnovariedade distintas de milho no passado, na América do Sul.

- Estas levas devem ter ocorrido por volta de 5.000 anos atrás para a primeira delas e por volta de 2.000 anos para a segunda. Uma terceira, mais recente, ainda é possível de ter ocorrido, seguindo mais ou menos o caminho da segunda, mas ficando mais confinada a região leste do Brasil.

- Estas levas só se explicam pela influência do homem, que foi o agente difusor desta planta, seja através de migrações, onde levou consigo amostras desta planta, seja por troca ou mesmo por conquistas.

- Os dados sugerem que existiu uma relativa integração humana na parte sul do continente, ligando culturalmente populações humanas desde o Chile até o Paraguai e Brasil, como é mostrado pelo compartilhamento de alelos de milho nestas áreas.

- Vemos ainda que os tipos de milho da região dos Andes Centrais - Peru, historicamente tiveram pouca influência na formação dos genótipos de milho presentes na região das terras baixas.

- Este padrão perdura até os dias de hoje, fato este que deve ser o resultado do modelo de colonização européia no Novo Mundo, onde, de modo geral, a região das terras baixas do continente foi colonizada pelos portugueses e as terras altas pelos espanhóis, mantendo este relativo isolamento entre os habitantes das duas regiões.

- Deste modo, as diversas amostras de milho que foram encontradas em Januária, apresentam uma relação muito maior e direta com materiais da América Central, do que dos Andes, indicando que, culturalmente, principalmente em termos de alimentação, as populações de Januária receberam uma influência maior de populações humanas das terras mais ao norte e não da região dos Andes Centrais.

- Aparentemente as barreiras culturais humanas foram muito mais fortes, importantes e decisivas na origem, seleção e difusão dos gêneros animais e vegetais que o homem utilizava em seu dia a dia, do que as própria barreiras geográficas. 
- Pelo padrão genético dos alelos, acreditamos que a subespécie com maior chance de ser o ancestral direto do milho seja a Z. mays parviglumis

Feijão

- A amostra arqueológica de Januária se trata da espécie Phaseolus vulgaris e não da espécie Ph. lunatus.

- O tipo básico genético da proteína Phaseolina presente na amostra de Januária é do tipo " $\alpha$ " e não do tipo " $\beta$ ".

- Diversos alelos foram encontrados nas diferentes amostras analisadas. De modo geral a distribuição destes alelos segue um padrão geográfico, onde todos os alelos oriundos de amostras da região desde o México até o norte da América do Sul (Colômbia/ Equador/ norte do Peru), ficaram em um mesmo grupo, a que chamamos de grupo Norte, enquanto, no outro grupo de alelos, só estavam presentes alelos oriundos de amostras do Sul do Peru e da Argentina, e que chamamos de grupo Sul.

- Aparentemente os alelos do grupo Norte são os mais antigos, indicando que a origem do feijão deve ter-se dado naquela região.

- Já as populações de feijão com alelos do Grupo Sul se originaram a partir de populações do grupo Norte, posteriormente.

- Alguns indivíduos que geograficamente pertencem ao Grupo Sul, apresentaram alguns alelos intermediários, indicando uma certa influência de ambos os grupos, ou mesmo isto podendo ser vestígios da história de diferenciação das populações do Sul, a partir das do Norte.

- Isto indica que, evolutivamente, o feijão deve ter tido apenas um centro de origem e todos os diferentes tipos de feijão hoje existentes evoluíram a partir de uma mesma população ancestral. Isto vai de encontro com algumas teorias que dizem que o feijão pode ter tido mais de um centro de origem, independentes.

- Pelo padrão dos alelos, aparentemente as populações de feijão das regiões do Norte (México até Norte da América do Sul) mantiveram um maior contato e troca de 
alelos, mostrado pela maior homogeneização de alelos deste grupo entre as diferentes regiões geográficas ai incluídas.

- Já o contato deste grupo com populações mais ao sul do continente aparentemente foram menores, fazendo com que os alelos entre estes dois grupos apresentem uma maior distinção.

- Novamente, como dissemos para o milho, o provável responsável pela criação destes grupos deve ter sido o próprio homem, onde barreiras culturais devem ter influído na difusão de materiais entre as diferentes regiões, criando populações de plantas distintas, além do contrário, onde nos lugares em que o homem mantinha uma maior circulação, deve ter promovido um maior contato entre indivíduos/ genótipos oriundos de diferentes populações de plantas de feijão, permitindo que ocorresse recombinação entre estas, resultando em uma maior homogeneização dos alelos presentes entre determinadas populações desta espécie.

- É interessante notar que estes grupos geográficos de influência humana sobre os genótipos dos materiais cultivados são praticamente os mesmo tanto em relação ao milho como ao feijão.

- A amostra de Januária apresentou 6 alelos distintos, sendo que destes, dois são exatamente iguais aos alelos do grupo do Norte, sendo os outros 4 alelos exclusivos. Destes 4 alelos exclusivos, dois são muito próximos a alelos do grupo do Norte e os outros são intermediários. A amostra não apresentou nenhum alelo exatamente igual ao encontrado em indivíduos do grupo Sul

- Isto sugere que, geneticamente, a amostra de Januária possui um maior grau de relação com alelos presentes em populações do grupo do Norte, mas também apresenta vestígios de um certo grau de contato com alelos mais relacionados a populações mais do centro sul andino.

- De modo geral, esta amostra de feijão de Januária confirma os dados levantados com as amostras de milho, onde sugerem que as populações de Januária possuíam uma relação ou influência de materiais cultivados muito maior com amostras vindas da região da América Central e norte da América do Sul e muito pouco com amostras da região dos Andes Centrais, como Peru. 
- Com base nestes dados e em dados históricos, acreditamos que mesmo a amostra de feijão de Januária pertencendo ao final do século 17, é bem provável que se trate de um material que não sofreu influência dos colonizadores europeus, refletindo um material que já era cultivado na região desde tempos mais remotos.

- Observamos ainda que a diversidade genética interespecífica dentro do gene de feijão estudado é maior do que a observada dentro do gene estudado de milho.

- Por último, gostaríamos de dizer que este trabalho demonstra que os dados oriundos de amostras de plantas cultivadas, podem servir, em paralelo, para vislumbrarmos a história do próprio homem nas Américas. 


\section{REFERÊNCIAS BIBLIOGRÁFICAS}

AGUIAR-PERECIn, M.L.R.. Bandamento-C e tipos de heterocromaina em milho. In:_Tópicos de citogenética e evolução de plantas. Sociedade Brasileira de Genética, 1985. 240p.

ALLABI, R.G; OÕDONOGHUE, K; SALLARES, R; JONES, M.K; BROWN, T.A.. Evidence for the survivel of ancient DNA in charred wheat seeds from european archaeological sites. Ancient Biomolecules. v. 1, p. 119-129, 1997.

ALLABY, R.G. \& BROWN, T.A.. Network analysis provides insights into the evolution of 5S rDNA arrays in Triticum and Aegilops. Genetics. 2000. In press.

BANDELT, H.J; FORSTER, P; SYKES, B.C; RICHARDS, M.B. Mitochondrial portraits of human populations using median networks. Genetics, v. 141, p. 743753. 1995.

BEADLE, G.W. Teosinte and the origin of maize. Journal of Heredity, v. 30, p. 133$138,1939$.

BEADLE, G.W. The ancestry of corn. Scientific American, v. 242, p. 96-103. 1980.

BEADLE, G.W.. The mistery of maize. Field Museum Bulletin, v. 43, p. 3-11, 1972.

BENZ, B. Racial systematics and the evolution of Mexican maize. In. Manzanilla - Ed. Studies in the neolithic and urban revolutions. B.A.R. International Series 349, Oxford, England, p. 121-136. 1987.

BIRD, R.MCK. Maize evoution from 500 B.C. to the present. Biotropica, v. 12, p. 3041, 1980.

BIRD, R.MCK., DIAS JR., O.; CARVALHO, E.T. Subsídios para a arqueobotânica no Brasil: o milho antigo em cavernas de Minas Gerais, Brasil. Revista de Arqueologia, v. 6, p.14-31, 1991. 
BRIEGER，F.G.; GURGEL， J.T.A.; PATERNIANI， E.; BLUMENSCHEIN, A.; ALLEONI, M.R. Races of maize in Brazil and other Eastern South American countries. National Academy of Science; National Research Council Publication No. 593. 1958. 293 p.

BUENO, E. Capitães do Brasil: A saga dos primeiros colonizadores. Objetiva, Rio de Janeiro, 1998. $288 \mathrm{p}$.

CANO, R.J; POINAR, H.N; PIENIAZEK, J; ACRA, A; POINAR, G.O. Amplification and sequencing of DNA from a 120-135- million-year-old weevil. Nature, 363: 536-538. 1993.

CASCUDO, L.C. História da alimentação no Brasil. Editora da USP - São Paulo, 1983, 926p.

COLLINS, G.N. Teosinte in Mexico. Journal of Heredithy, v. 12, p. 339-350.1921.

DE WET, J.M.J. \& HARLAN, J.R. Origin of maize: tripartite hypothesis. Euphytica, v. 21, p. 271-279, 1972.

DEBOUCK, D.G. Primary diversification of Phaseolus in the Americas: Three centers? Plant Genetic Resources Newsletter. V. 67, p. 2-8, 1986.

DEBOUCK, D. Systematics and morphology. In: Schoonhoven, A. \& Voysest, O. (Ed.). Commom Beans - Research for crop improvement. CIAT, 1991, p 55-118.

DEBOUCK, D.G; Toro, O; Paredes, M; Johnson, W.C; Gepts, P. Genetic diversity and ecological distribution of Phaseolus vulgaris (Fabaceae) in northwestern South America. Economic Botany. 47(4), p. 408-423, 1993.

DENNIS, E.S; SACHS, M.M; GERLACH, W.L; FINNEGAN, E.J; PEACOCK, W.J. Molecular analysis of the alcohol dehydrogenase 2 (Adh2) gene of maize. Nucleic Acids Research, v. 13 (3), p. 727-743, 1985.

DOEBLEY, J.F; GOODMAN, M.M; STUBER, C.W. Exceptional genetic divergence of Northern Flint Corn. American Journal of Botany, v. 73, p. 64-69, 1986.

DOEBLEY, J.F. Molecular evidence for gene flow among Zea species. BioScience, v. 40, p. 443-448, 1990.

FREITAS, F.O. Descrição e análise de material vegetal de sítios arqueológicos da região de Januária, Minas Gerais. Piracicaba, 1996. 83p. (Mestrado) - Escola Superior de Agricultura "Luiz de Queiroz", Universidade de São Paulo. 
FREITAS, F.O; MARTINS, P.S. Calcite crystals inside archaeological plant tissue Journal of Archaeological Science, v. 27 (11), nov., pp 981-985, 2000.

GALINAT, W.C. The origin of maize as shown by key morphological traits of its ancestor. Maydica, v. 28, p. 121-138, 1983.

GEPTS, P \& DEBOUCK, D. Origin, domestication, and evolution of the common bean (Phaseolus vulgaris). In: Schoonhoven, A. \& Voysest, O. (Ed.). Commom Beans - Research for crop improvement. CIAT, 1991, p 7-53.

GEPTS, P. Biochemical evidence bearing on the domestiction of Phaseolus (Fabaceae) beans. Economic Botany, v. 44(3 suplement), p. 28-38, 1990.

GEPTS, P; OSBORN, T.C; RASHKA, K; BLISS, F.A. Phaseolin-protein variability in wild forms and landraces of the common bean (Phaseolus vulgaris): evidence for mulltiple centers of domestication. Economic Botany, v.40, p. 451-468, 1986.

GOLENBERG, E.M; GIANNASI, D.E; CLEGG, M.T; SMILEY, C.J; DURBIN, M; HENDERSON, D; ZURAWSKI, G. Chloroplast DNA sequences from a Miocene Magnolia species. Nature, 344: 656-658, 1990.

GOLOUBINOFF P., PÄÄBO S., AND WILSON A.C. 'Evolution of maize inferred from sequence diversity of an Adh2 gene segment from archaeological specimens'. Proceeds of National Academy of Science of USA (90): 1997-200, 1993.

GOODMAN, M. História e origem do milho. In Paterniani, E. (ed.). Melhoramento e produção do milho no Brasil. Fundação Cargill. 1978. 650p.

HARLAN, J.R. Agricultural origins: centers and noncenters. Science, v. 174, p. 468$173,1971$.

HARLAN, J.R.; DE WET, J.M.J. On the quality of evidence for origin and dispersal of cultivated plants. Current Antropology, v. 14, p. 51-55, 1973.

HERRMANN, B; HUMMEL, S; Ancient DNA: recovery and analysis of genetic materials from paleontological, archeological, museum, medical, and forensic specimens. Springer Verlag, New York - USA, 1994, 262p.

HIGUCHI, R.G, WILSON, A. Recovery of DNA from extinct species. Fed. Proceeds, 43: 1557. 1984.

HIGUCHI, R.G; WRISCHNIK, L.A; Oakes, E; George, M; Tong, B; Wilson, A.C. Mitochondrial DNA of the extint quagga: relatedness and extent of postmortem change. Journal of Molecular Evolution, v. 25, p. 283-287, 1987. 
ILTIS, H.H. Maize evolution and agricultural origins. In. Soderstrom, T; Hilu, K; Campbell, C; Barkworth, M - Eds. Grass systematics and evolution. Smithsonion Institute Press, Washington, DC. 1987, p. 195-213.

ILTIS, H.H. \& DOEBLEY, J.F. Taxonomy of Zea (Gramineae). II. Subspecific categories in the Zea mays complex and generic synopsis. American Journal of Botany, v. 67, p. 994-1004, 1980.

JUNQUEIRA, P.A.; MALTA, I.M. Horticultores e ceramistas pré-históricos do nordeste de Minas Gerais. Arquivos do Museu de História Natural/UFMG, v. 6/7, p. 275-289, 1981/82.

KAMI, J.A. \& GEPTS, P. Phaseolis nucleotide sequence diversity in Phaseolus. I. Intraspecific diversity in Phaseolus vulgaris. Genome, v. 37, p. 751-757, 1994.

KAMI, J; VELÁSQUEZ, V.B; DEBOUCK, D.G; GEPTS, P. Identification of presumed ancestral DNA sequences of Phaseolin in Phaseolus vulgaris. Proceeds of National Academy of Science of USA, v.92, p. 1101-1104, 1995.

KATO, T.A. Chromosome morphology and the origin of maize and its races. Evolutionary Biology, v. 17, p. 219-253, 1984.

LAHR, M.M. A origem dos ameríndios no contexto da evolução dos povos mongolóides. Revista USP, editora USP março/maio, p 70-81, 1989.

LAWLOR, D.A; DICKET, C.D; HAUSWIRTH, W.W; PARHAM, P. Ancient HLA genes from 7500 year-old archeological remains. Nature, v. 349, p. 38-41, 1991.

LEWIN, R. Fact fiction and fossil DNA. New Scientist, v. january, p. 38-41, 1994.

LINDAHL, T; NYBERG, B. Rate of depurination of native deoxyribonucleic acid. Biochemistry, v.11, p. 3610-3618, 1972.

LINS, W. O médio São Francisco - Uma sociedade de pastores guerreiros. Brasiliana, vol 377. Ed. Nacional, 1983. 150 p.

MANGELSDORF, P.C. Teosinte the closest relative of maize and the genetic nature of teosinte. In Mangelsdorf, P.C. (ed.) Corn, its origin, evolution and improvement. Cambridge, Belknap Press, capts. 3-4. 1974.

MANGELSDORF, P.C. The origin of corn. Scientific America, v. 254, p. 80-86, 1986.

MANGELSDORF, P.C. \& REEVES,R.G. The origin of indian corn and its relatives. Texas Agriculture Experimental Station Bulletin, v. 574, 1939. 
MCCLINTOCK, B. Chromosome constitutions of Mexican and Guatemalan races of maize. Annual Report of Department of Genetics of Carnegie Institute Washington, v. 59, p. 461-472, 1959.

MCCLINTOCK, B.; KATO, T.A.Y.; BLUMENSCHEIN, A. Chromosome constitution of races of maize. Colégio de Postgraduados, Chapingo, México, 1981. 517p.

MONTGOMERY, E.G. What is an ear of corn? Popular Science Monthly, v.68, p. 55$62,1906$.

NEVES, W; ZANINI, M.C; MUNFORD, D; PUCCIARELLI, H.M. O povoamento das américas à luz da morfologia craniana. Revista USP, março/maio, p. 96-105, 1989.

PÄÄBO, S; GIFFORD, J; WILSON, A. Mitochondrial DNA sequences from a 7.000year old brain. Nucleic Acids Research, v.16, p. 9775-9787, 1988.

PÄÄBO, S; HIGUCHI, R.G, WILSON, A.C. Ancient DNA and polymerase chain reaction. The Journal of Biological Chemistry, v. 264, p. 9709-0712, 1989.

PATERNIANI, E. AND GOODMAN, M.M. Races of maize in Brazil and adjacentes areas. CIMMYT. Mexico, 1977. 95 p.

PENA, S.D.J; SILVA, D.R.C; SANTOS, F.R. Utilização de polimorfismos de DNA do cromossomo $\mathrm{Y}$ no estudo do povoamento das Américas. Revista USP, março/maio, p. 44-57, 1989.

PESSENDA, L.C.R.; CAMARGO,P.B. Datação radiocarbônica de amostras de interesse arqueológico e geológico por espectrometria de cintilação líquida de baixo nivel de radiações de fundo. Química Nova, v. 14, f. 2, p. 98-103, 1991.

PIPERNO, D.R. The application of phytolith analysis to the reconstructio of plant subsistence and environments in prehistoric Panama. Phd Tesis. Temple University. 1978. 459p.

PRAGER, E.L; LOWENSTEIN, J.M; SARICH, V.M.. Mammoth albumin. Science, July, p. 287-289, 1980

PROUS, A. L'archéologie au Brésil: 300 siécles d'occupation humaine. L'Anthropologie, v. 90, p. 257-306, 1986.

PROUS, A. O povoamento da América visto do Brasil: uma perspectiva crítica. Revista USP, março/maio, p. 8-21, 1989. 
PROUS, A. Alimentação e "arte" rupestre: nota sobre alguns grafismos pré-históricos brasileiros. Revista de Arqueologia, São Paulo, v. 6, p. 1-15, 1991.

PROUS, A. Arqueologia brasileira. Brasília, DF: Editora Universidade de Brasília, 1992. 605p.

PROUS, A.; JUNQUEIRA, P.A.; MALTA, I.M. Arqueologia do alto médio São Francisco. Região de Januária e Montalvânia. Revista de Arqueologia, Belém, v. 2, p. 59-72, 1984.

RANDOLPH, L.E. Cytogenetic aspects of the origin and evolutionary history of corn. In Sprague, G.F. (ed.). Corn and corn improvement. Academic Press. 1955.

REEVES, R.G. \& MANGELSDORF, P.C. A proposed taxonomic change in the tribe Maydeae (Family Gramineae). American Journal of Botany, v. 29, p. 815-817, 1942.

REGO, L.M. O vale do São Francisco. Ed. Renascença, 1945. 245pg.

RIBEIRO DOS SANTOS, A; SANTOS, S; MACHADO, A.L; GUAPINDAIA, V; ZACO, M. Heterogeneity of mitochondrial DNA haplotypes in Pre-Columbian natives of the Amazon region. American Journal of Physical Anthropology, v. 101, p. 29-37, 1996.

ROLLO, F. Characterisation by molecular hybridization of RNA fragments isolated from ancient (1400 B.C.) seeds. Theoretical and Applied Genetics, v. 71, p. 330-333, 1985.

ROLLO, F; VENANZI, F.M; AMICI, A. Nucleic acids in mummified plant seeds: biochemistry and molecular genetics of pre-Columbian maize. Genetical Researches, v. 58, p. 193-201, 1991.

ROOSEVELT, A.C. Paleoindian cave dwellers in the Amazon: The peopling of the Americas. Nature, v. 272, p. 373-383, 1996.

STEWARD, J.H. South American Cultures: Na Interpretation. In: Handbook of South American Indians, V. 2. Cooper Square Publisher - New York, 1963. 916p

TAYLOR, R.E; MEIGHAN, C.W. Chronologies in New World archaeology. Academic Press, N.Y., 1978. 578p.

THOMPSON, J.D; HIGGINS, D.G; GIBSON, T.J. CLUSTALW: improving the sensitivityof progressive multiple sequence alignment through weighting, positio-specific gap penalties and weigt matrix choice. Nucleic Acids Research, v. 22, p. 4673-4680, 1994. 
VASCONCELOS, D. História antiga de Minas Gerais. Ed. Itatiaia Ltda, Belo Horizonte, 1974. 283p.

VELOSO, T.P.G.; RESENDE, E.M.T.P. Vestígios alimentares nos sítios arqueológicos sob abrigos de Minas Gerais. Anais III Congresso ABEGUA, Belo Horizonte: p. 389-414, 1992.

WEATHERWAX, P. Early history of corn and theories as to its origin. In Sprague, G.F. (ed.) Corn and corn improvement, Academic Press. 1955. 